\title{
LOS TEXTILES YCHSMA DEL HORIZONTE TARDÍO EN EL ENTIERRO DE ARMATAMBO
}

\author{
MARY FRAME \\ INSTITUTO DE ESTUdIOS ANDINOS, BERKELEY - INVESTIGADORA ASOCIADA \\ framem@hotmail.com \\ FRANCISCO VALLEJO \\ UNIVERSIDAD NACIONAL FEDERICO VILLARREAL \\ f_vallejob@yahoo.com \\ MARIO RUALES \\ Ministerio de Cultura. Programa QApac Ñan. \\ Director del Proyecto de Puesta en USO SoCIAL - HuAYCÁn de Cieneguilla \\ mario.rualesm@yahoo.com.pe \\ WALTER TOSSO \\ Fundación Museo Amano. Director del Proyecto Aroueológico de Pisouillo - Las Shicras \\ w_tosso@hotmail.com
}

\section{RESUMEN}

Un contexto funerario, excavado en 1982, en el sitio de Armatambo proporciona la base para describir el estilo de textiles Ychsma durante el Horizonte Tardío. Los datos textiles (tipos de prendas de vestir, la iconografía, la disposición de diseño, las fibras, las estructuras de tejido, hilos, colores, etc.) son suficientemente extensos para distinguir los tipos de textiles Ychsma con textiles de otros estilos, y para identificar textiles semejantes en colecciones de museos. La procedencia de los textiles Ychsma en las colecciones de los museos, es considerada para sugerir el ámbito de interacción de la cultura Ychsma en la costa central.

Palabras Clave: Ychsma, textiles, Armatambo, costa central.

\section{ABSTRACT}

A burial context, excavated in 1982 at Armatambo, provides the basis for describing the Ychsma textile style during the Late Horizon. The textile data (types of garments, images, design lay-out, fibers, fabric structures, yarn spin, colors, etc.) are extensive enough to distinguish many types of Ychsma-style garments from those of other styles, and to identify similar textiles in museum collections. The provenience information on Ychsma textiles from museum collections suggests the extent of the Ychsma sphere of interaction on the Central Coast.

KEYwoRDS: Ychsma, textiles, Armatambo, central coast. 
El estilo Ychsma, en particular los textiles de este estilo, no son bien conocidos a través de la arqueología. Sin embargo, las fuentes etnohistóricas indican que el señorío Ychsma ocupó las secciones media y baja de los valles de Rímac y Lurín, durante los periodos Intermedio Tardío y Horizonte Tardío, y su centro más famoso fue el Santuario de Pachacamac. Pequeños subgrupos, que ocuparon los sitios a lo largo de los canales en los valles inferiores, conformaron el señorío y compartieron un estilo común de vestir, un lenguaje común o dialecto y un origen mítico (Rostworowski 1977a, 1977b y 1990). Armatambo es un sitio Ychsma cercano al brazo del canal de Surco (o Sulco), en la parte baja del valle del Rímac. El Padre Bernabé Cobo, quien conoció Armatambo en el siglo XVII, remarcó su suntuoso templo y las casas elaboradas con figuras pintadas en las paredes, también puso en evidencia la presencia de una gran población (Cobo 1882 [1639], citado en Díaz y Vallejo 2005: 227). Actualmente, poco del esplendor de Armatambo es visible porque la mayoría del sitio, se encuentra cubierta de casas. En 1982, justo delante de la excavadora, tres de los coautores del presente artículo excavaron una tumba que contenía muchos tejidos de estilo local. Este contexto importante proporciona una base para describir los textiles de estilo Ychsma durante el Horizonte Tardío.

En los últimos años, un considerable número de enterramientos de las épocas tardías han sido excavados en el territorio Ychsma en sitios como: Armatambo, Puruchuco / Huaquerones y Rinconada Alta (Cock y Goycochea 2004; Díaz y Vallejo, 2002a, 2002b y 2005; Díaz y Landa 2009; Frame et al. 2004; Guerrero 2004), pero los contextos funerarios con concentraciones de textiles de estilo local no son abundantes. Los textiles recuperados por los arqueólogos durante excavaciones en Pachacamac incluyen tejidos llanos y a cuadros de un contexto femenino con fechado correspondiente al periodo Intermedio Tardío, así como textiles más elaborados que fueron identificados como Ychsma del Horizonte Tardío (Eeckhout 1998, 1999; Feltham 2002). Los textiles publicados proporcionan datos útiles sobre las fibras, colores y estructuras específicas de tejidos Ychsma, pero el pequeño número de ejemplos ofrece una limitada visión del estilo. Los intentos por diferenciar los textiles Ychsma sin procedencia (a veces denominado estilo "Rímac" o "Pachacamac") de otros estilos han puesto en relieve ciertos distintos tipos de tejidos, tales como tapices de algodón (Engelstad 1980; Jiménez Borja 1999; Stone-Miller 1992; Young-Sánchez 1992), pero nuevamente la visión del estilo está lejos de ser completa. Fotos y dibujos de unos tapices de algodón del contexto de Armatambo son publicados (Frame 2010: Figuras 13-15; Vallejo 1988: Figuras 14, 15 y 21).

Algunas colecciones tempranas y excavaciones en Pachacamac incluyen textiles Ychsma, pero también estilos foráneos de textiles que abarcan un largo periodo (Schmidt 1910 y 1929; Uhle 1991). La presencia de estilos originarios de lugares tan lejanos como el valle de Lambayeque, indica que los peregrinos religiosos viajaban largas distancias hacia el santuario de Pachacamac durante un periodo de muchos siglos. La mezcla de estilos textiles presentes en el territorio Ychsma durante los periodos tardíos probablemente refleja la presencia de residentes locales y peregrinos, las incursiones periódicas de grupos étnicos vecinos de las elevaciones más altas o valles adyacentes, así como los incas y los especialistas extranjeros (mitimaes) que fueron re-asentados en la época incaica ${ }^{1}$.

Con tantos estilos representados en sitios de los valles de Lurín y Rímac, una descripción segura de tejidos del estilo Ychsma requiere de un contexto arqueológico con asociaciones. La tumba que fue excavada en Armatambo en 1982 es la única en tener una amplia gama de tejidos de la elite en el estilo local. Más de setenta textiles de la tumba fueron depositados en el Museo de Arqueología y Antropología de la Universidad Nacional Mayor de San Marcos por los arqueólogos Mario Ruales, Francisco Vallejo y Walter Tosso, quienes excavaron la tumba y aperturaron el fardo. Los textiles son de estilo local y el contexto está fechado en el Horizonte Tardío sobre la base de un plato de estilo local Inca que fue encontrado en la tumba (Vallejo 1988: 398). Los textiles del contexto Armatambo tienen grupos de rasgos

1 Los estudios de restos no textiles y de patrones funerarios también indican la presencia de diferentes grupos durante el Horizonte Tardío (Díaz y Vallejo 2004; Vallejo 2009). 
distintivos, que son descritos aquí y luego se utilizan para identificar otros ejemplos de textiles Ychsma en colecciones de museos. Las procedencias de los textiles en colecciones de museos proporcionan una aproximación de la esfera de interacción Ychsma en la Costa Central durante los periodos tardíos.

\section{TeCnología y estilo}

Numerosos aspectos estilísticos deben ser considerados cuando trabajamos para definir un estilo textil. La iconografía, la disposición del diseño, los patrones de simetría, y las preferencias cromáticas a veces proporcionan señales reconocibles instantáneamente para la identificación de un estilo, pero los rasgos de pequeña escala son también importantes. Algunos textiles carecen de iconografía y de patrones, pero todos tienen, como mínimo, la torsión de los hilos y la estructura del tejido. Las características técnicas permiten que los textiles llanos sean considerados, e incluso contribuyan a la definición de un estilo. De los atributos técnicos, a menudo es posible inferir qué tipos de telares, husos y técnicas de hilado fueron empleados.

Las mayores diferencias técnicas y de estilo tecnológico (Lechtman 1977) son visibles a nivel regional. Los especialistas en textiles reconocen al menos cuatro tradiciones regionales en los Andes ${ }^{2}$. Cada tradición se caracteriza fundamentalmente por las similitudes en los materiales, el hilado, las técnicas de tejido, los acabados, los tipos de prendas de vestir, los tipos de telar y husos. Aun cuando el estilo específico no puede ser identificado, los especialistas pueden a menudo ubicar un tejido dentro de una tradición tecnológica regional, como Jiménez (2009), por ejemplo, ha hecho. El estilo Ychsma pertenece a la tradición central y sur de la Costa.

Los estilos de los grupos étnicos vecinos pueden variar en características específicas, aunque comparten la misma tradición textil regional. A medida que más estudios técnicos son publicados, es posible distinguir entre los estilos locales de una región. El estilo Chancay, que se centró en los valles al norte del territorio Ychsma, también pertenece a la tradición central y sur de la costa, y comparte con el estilo Ychsma algunos, pero no todos, los tipos de prendas de vestir, las técnicas y la iconografía.

La torsión del hilo es un atributo técnico útil para distinguir entre algunos estilos de textiles. Tanto los hilanderos Ychsma y Chancay emplearon un huso con ambos extremos puntiagudos, permitiéndoles hilar con torsión en $\mathrm{Z}$ cuando el huso se orientaba verticalmente y con torsión en $\mathrm{S}$, cuando el huso estaba orientado horizontalmente ${ }^{3}$. En la terminología del hilado, S y Z se utilizan para distinguir la inclinación de las fibras en un elemento torcido a través de la correspondencia con la inclinación diagonal del trazo central en cada letra. Ambos estilos muestran una preferencia por los hilos de dos cabos (Z-2S) para las urdimbres (la primera serie de hilos paralelos que se coloca en el telar), y también utilizan los hilos de un solo cabo (hilado en S o Z) en ciertos casos. La notación Z-2S, significa que el hilo fue torcido por primera vez en la dirección Z, y luego dos hilos fueron retorcidos juntos en la dirección S. Las diferencias en las prácticas del hilado se pusieron en relieve, para establecer distinciones entre los estilos Ychsma y Chancay a nivel técnico. La elección de la fibra (algodón o camélido) es otra diferencia entre los estilos. Los textiles Ychsma son mayormente de algodón, con poca fibra de camélido y los textiles Chancay utilizan más fibra de camélido, junto con algodón.

Ciertas convenciones son seguidas en las ilustraciones y leyendas con el propósito de transmitir información sobre el tejido y la construcción de prendas Ychsma. Los textiles son mostrados con las urdimbres orientadas verticalmente, salvo que se indique lo contrario. Las tramas (los hilos que se en-

2 Las tradiciones regionales más conocidas son: la tradición norteña, la tradición de las tierras altas centrales, la tradición centro-sur y la tradición de la costa central y sur.

3 La diferencia de direccionalidad en la torsión del hilo surge debido a que el huso, de orientación vertical, se activa con los dedos en el extremo proximal, donde se tuerce la fibra en hilo, mientras que cuando el huso está orientado horizontalmente, se activa en el extremo distal, opuesto a donde se tuerce la fibra en hilo (Rowe 1996). 
trecruzan con las urdimbres) son orientadas en la dirección opuesta. En las leyendas, primero se indica la dimensión de la prenda en la dirección de la urdimbre. Las camisas Ychsma de tapiz, por ejemplo, difieren en la orientación de la urdimbre de las túnicas Inca de tapiz de las tierras altas, y las convenciones de la ilustración y la leyenda deben transmitir esto.

Telas de los ligamentos recurrentes, tales como tapices y brocados, son atributos tecnológicos que serán considerados aquít . El tapiz es un tejido con un ligamento llano con tramas discontinuas y apretadas (cara de trama). El tapiz ranurado, una variante común en los estilos Ychsma y Chancay, tiene aberturas o ranuras entre las áreas locales de color. Cuando las aberturas son largas, son cerradas ya sea por costuras posteriores, o por varios tipos de trabados realizados durante la confección del tejido. El tapiz ranurado Ychsma, cuando es considerado en combinación con las fibras, los colores, la iconografía, y la técnica usada para terminar la tela, surge la diferencia de otros estilos de la costa.

El brocado, que es otra técnica para hacer figuras con las tramas, tiene un campo de ligamento llano y además tramas suplementarias y discontinuas en las áreas locales. Las tramas del brocado, que son tejidas entre las filas de tramas del tejido base, flotan por encima de un número de urdimbres y se sujetan por debajo de una o más urdimbres. Dos variantes de brocado, que se distinguen por la longitud de las tramas flotantes y el número de las urdimbres amarres, están presentes entre los brocados Ychsma en el contexto descrito aquí. Uno de los tipos, cuando se considera junto con la iconografía y otros atributos, es particularmente distintiva (Frame s.f.). Los detalles técnicos, junto con la iconografía, patrones y colores, que son presentados en las ilustraciones, serán empleados para describir el estilo de textiles Ychsma durante el Horizonte Tardío.

\section{La excavación de la tumba en Armatambo}

Armatambo, situado en la ladera oriental del Morro Solar, en el distrito de Chorrillos, fue un extenso sitio Ychsma con pirámides y otros tipos de arquitectura que pudieron haber sido de carácter administrativo o residencial (Díaz y Vallejo 2005: 226). Hoy en día, el sitio está cubierto casi completamente con casas construidas por inmigrantes a la costa. Cuando eran estudiantes de la Universidad Nacional Mayor de San Marcos en 1982, los arqueólogos Mario Ruales, Francisco Vallejo y Walter Tosso realizaron una excavación de rescate en el barrio conocido como "Mártir José Olaya Balandra" 5 . La excavación inicial fue ampliada a una segunda área, denominada sector D2 (Fig. 1), que estaba a punto de ser excavada para viviendas. El sector D2 fue una zona con silos o almacenes que habían sido reutilizados como cámaras funerarias, y la tumba del compartimiento D fue el más pequeño de los almacenes excavados. (Fig. 2, en primer plano a la izquierda) ${ }^{6}$.

La tumba revestida con adobe $(1,4 \times 1,8 \mathrm{~m})$ contenía dos cuerpos, así como ofrendas de diferentes tipos (Ruales et al 1983; Vallejo 1988). El fardo principal fue inicialmente apoyado en posición vertical en la esquina norte, pero se había caído. Dentro del fardo, había un hombre de aproximadamente 50

4 La terminología textil utilizada aquí sigue Rowe (2006), en lo posible.

5 Mercator Transversal Universal (UTM) coordenadas del Sector D2 son 8'652,975 N y 280,250 E (Ruales et al. 1983).

6 Algunos aspectos y textiles de la excavación fueron descritos por Francisco Vallejo (1988). Los planes para publicar el contexto más completo fueron suspendidos por la sustracción de sus mejores archivos de investigaciones y fotos mientras los tres arqueólogos se encontraban en Italia. Sólo quedaron unas pocas fotografías de la excavación. Ensamblar la mayoría de los textiles de la tumba en 1998 y 1999 para el presente estudio implicó revisar todos los textiles de los sectores D1 y D2 en el Museo de Arqueología y Antropología de la Universidad Nacional Mayor de San Marcos, correlacionándolos a los registros disponibles y los recuerdos de los arqueólogos. Los documentos consultados incluyen el informe del Instituto Nacional de Cultura (Ruales et al. 1983), inventarios de los arqueólogos (Ruales s.f.1; s.f.2) y el museo, las fotos del desenfardelamiento y las fichas de registro textil que se realizaron en la década de 1980 por Heiko Prümers (Prümers s.f.). 


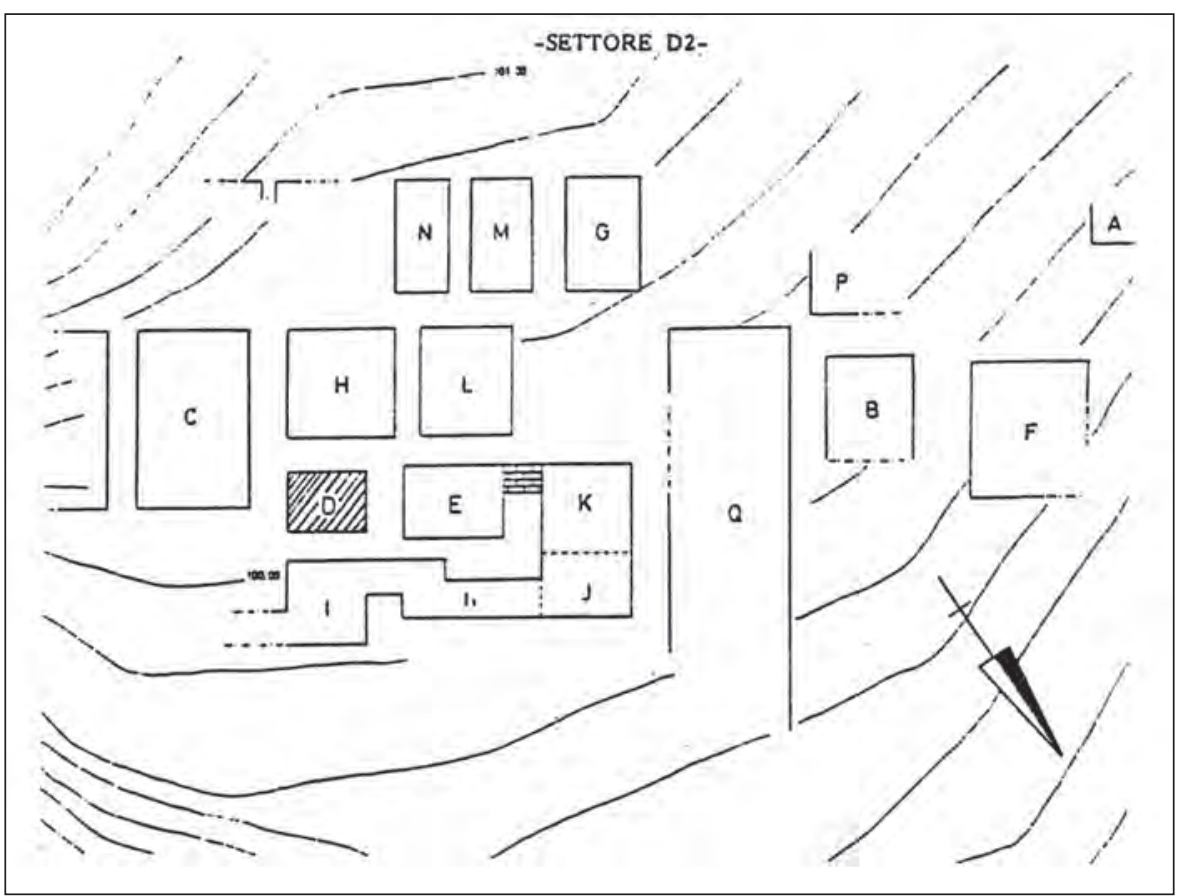

Figura 1. Plano arquitectónico de los almacenes en el Sector D2 de Armatambo, que fueron reutilizados como cámaras funerarias durante el Horizonte Tardío. El compartimiento D contenía el fardo funerario de un hombre de aproximadamente 50 años de edad, así como el cuerpo de una mujer joven sacrificada (Vallejo 1988).

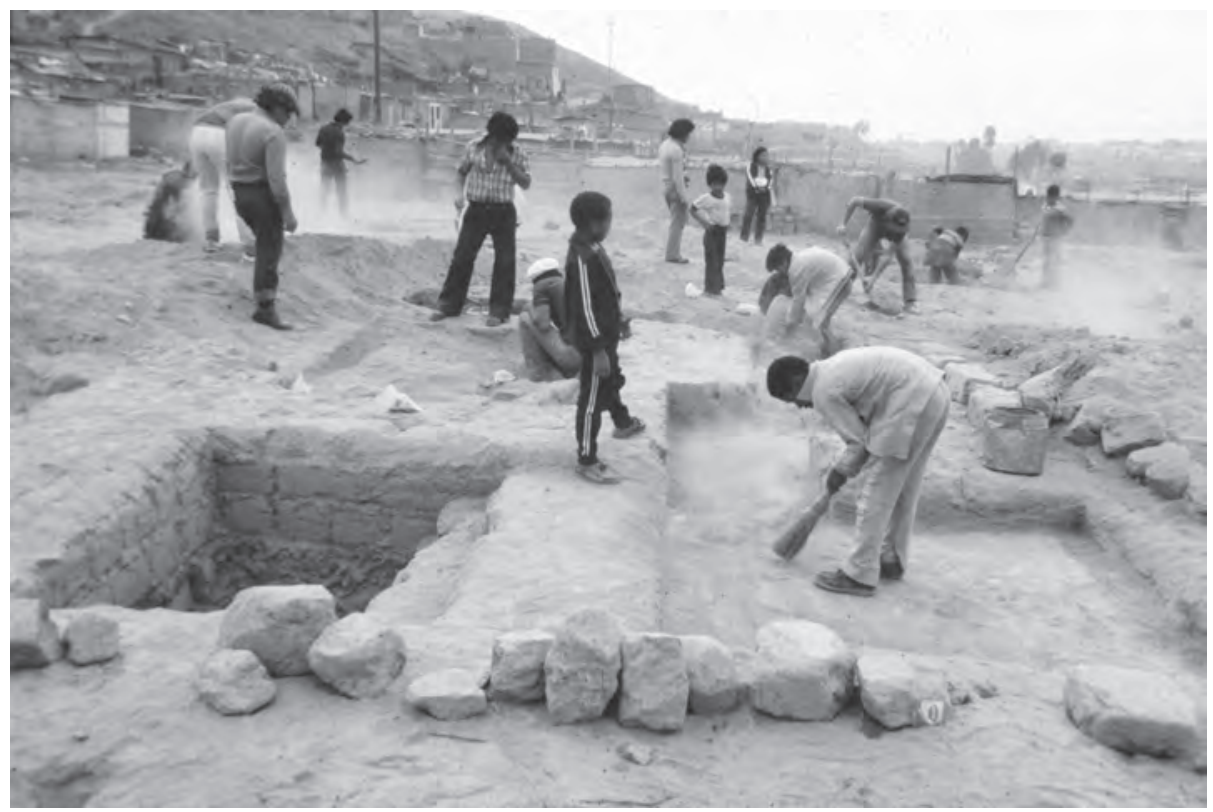

Figura 2. Compartimiento $D$, que contenía el fardo funerario, es la cámara rectangular más pequeña que se muestra en primer plano, hacia el lado izquierdo en la excavación del Sector D2 de Armatambo. Fotografiado por Mario Ruales, 1982. 
años de edad, en posición fetal, al que le fueron concedidos muchos ritos funerarios durante la preparación de su fardo. Tenía una grave enfermedad en la columna vertebral, llamada spondilo-artrosis, que debió haber deformado su postura. Tal vez en vida usó un bastón corto para apoyo y equilibrio, similar al que se encontró en la tumba. El segundo cuerpo de la tumba era el de una mujer joven, 18-20 años de edad. Ella estaba tendida boca abajo, con los brazos y piernas flexionadas hacia fuera del cuerpo. Ella fue aparentemente sacrificada con un pesado adobe que le habría roto la columna vertebral. Llevaba un vestido sencillo de algodón marrón grueso, que estaba demasiado frágil para recuperarse.

Durante la excavación de la cámara funeraria, se encontró una hilera de adobes a $15 \mathrm{~cm}$ bajo el nivel del piso (roto). Varios tipos de ofrendas aglutinadas fueron encontradas en la esquina sur-este en este nivel: bandas de tejido, paños llanos y decorados, nueve husos atados juntos, un collar de semillas (Nectandra?), una pulsera de conchas marinas, esculturas de arcilla incluyendo tres figurillas femeninas, un plato de estilo inca local y diez peces en tapiz. Al lado norte de la tumba, se encontraron un plato de arcilla sin decoración y una vara corta que pudo haber sido el bastón de apoyo (Ruales et al 1983; Vallejo 1988: 397-98).

\section{Tejidos del relleno de la tumba}

Una banda completa en tapiz del relleno de la tumba (\#54, Fig. 3) podría ser la cobertura exterior de una vincha rellenada, mientras que una banda de tapiz, que tiene un fleco añadido a lo largo, originalmente fue el borde de un gran manto (\#55, Fig. 4) ${ }^{7}$. Un fragmento de una banda colorida, que muestra un ligamento con tramas complementarias (\#51,363.02.2051), probablemente fue el borde inferior de una camisa. Los diez peces en tapiz de la tumba (\#57-66), se tejieron con un contorno irregular, son muy distintivos del estilo Ychsma en el Horizonte Tardío (\#59, Fig. 5). Están elaborados en algodón en el ligamento de tapiz ranurado y los bordes irregulares están perfectamente acabados con nudos ocultos dentro de ribetes tubulares. La combinación de crema, azul y varios tonos de marrón es el típico esquema de color de los textiles de algodón Ychsma. Los peces en tapiz originalmente fueron cosidos a un manto de ligamento llano, similares a los mantos grandes encontrados dentro del fardo que tiene parches en tapiz cosidos. Si bien es común que los tapices sean de algodón, el uso de la fibra de camélido para algunas o todas las tramas del tapiz (Fig. 3) tampoco es raro. Como la mayoría de los tapices Ychsma, las urdimbres de algodón en estos tres ejemplos son Z-2S o Z-3S y las tramas son de un cabo hilado en $\mathrm{Z}$. El uso de tramas de un cabo hilado en $\mathrm{Z}$ es frecuente en los tapices Ychsma, y bastante raro en los textiles Chancay ${ }^{8}$.

Un fragmento de un vestido se encontró también en el relleno de la tumba. El fragmento es de

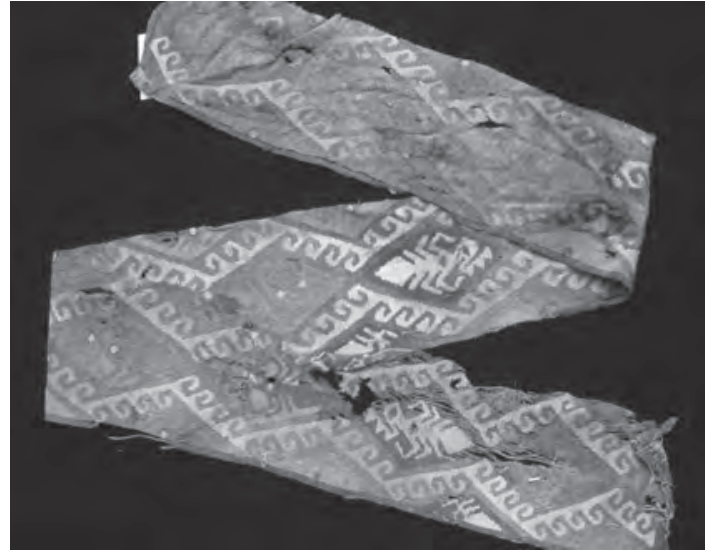

Figura 3. Banda en tapiz con representaciones de camarones de río, ubicado en el relleno de la tumba. Podría corresponder a la cubierta externa de lo que originalmente fue una vincha rellenada. $107 \times 9.5 \mathrm{~cm}$. \#54, SM 363.02.2050.

7 Los textiles del relleno de esta tumba recibieron números entre 50 y 78 en la secuencia de los tejidos recuperados de los Sectores D1 y D2 de la excavación (Ruales s.f.2). Los textiles del fardo recibieron números entre 1 y 42 durante el desenfardelamiento.

8 Los datos sobre el tipo de torsión del hilo de textiles Chancay, recolectados en la superficie, muestran que menos del 3\% de una muestra de 553 textiles tienen hilos en un cabo, torcido en Z (Kula 1991: Tabla 1). 
ligamento llano equilibrado, y la construcción de los hilos es la misma que en los ejemplos de tapiz. Los pliegues angostos fueron asegurados con varias filas de puntadas, como se puede ver al lado izquierdo del fragmento (\#56, Fig. 6). Los del lado derecho se han deshecho, aunque las dobleces de los pliegues permanecen. Este es un fragmento del canesú de un vestido Ychsma, que normalmente tiene una sección llana en el centro, flanqueado por pliegues. Un dibujo de un vestido de Pachacamac con pliegues en el canesú (Uhle 1991: 68, Figure 94) muestra el tipo de vestido llevado por la mujer costeña. Los pliegues son de espaciado estrecho y se mantienen en su lugar por las costuras del hombro y talle y las líneas de puntadas, aunque el dibujo de Uhle no muestra la costura en el talle.

Grandes fragmentos de dos mantos brocados fueron encontrados en el relleno, encima de los restos humanos. Ambos tienen indicios de haber sido utilizados en diferentes contextos antes de ser colocados en esta tumba. Un panel de color amarillo con figuras, claramente masculinas (\#50, Fig. 7a), es un brocado elaborado en diferentes colores de algodón teñido, incluyendo azul, verde, rosa y dos tonos de marrón. La asimetría de las figuras frontales es inusual y pudo haber sido dibujada a propósito (Fig. 7b). Las figuras fueron tejidas en el tipo más común de brocado: las tramas suplementarias que flotan por encima de un número impar de urdimbres (generalmente cinco) y se sujetan por debajo

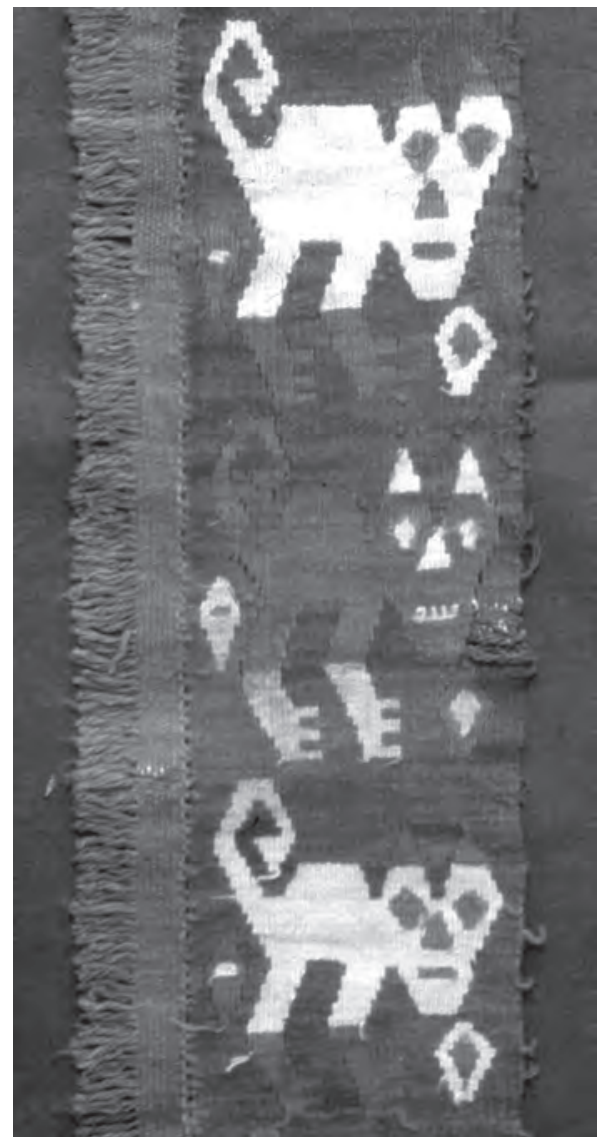

Figura 4. El fragmento de borde con flecos de manto mostrando felinos fue hallado en el relleno de la tumba. El borde en tapiz ranurado y la banda con flecos fueron tejidos con hilos de algodón. $100 \times 10 \mathrm{~cm}$. \#55, SM 363.02.1982.

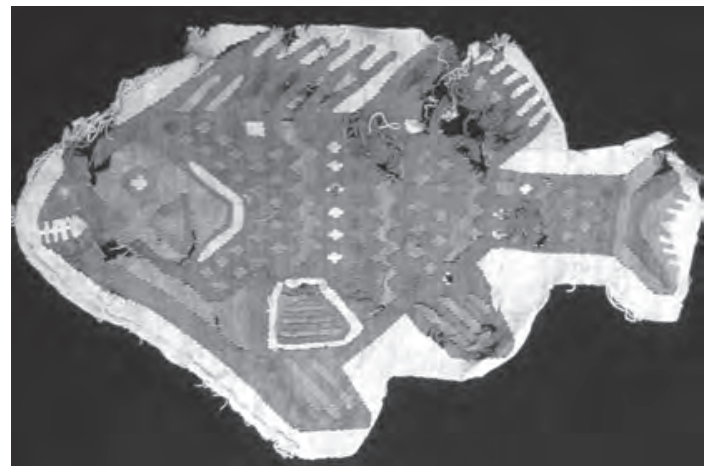

Figura 5. Diez parches o pastillas de tapices en forma de peces fueron encontrados en el relleno, sobre el fardo. 29.5 (la dirección de la urdimbre es horizontal) x 18.5 cm. \#59, SM 363.02.2044.

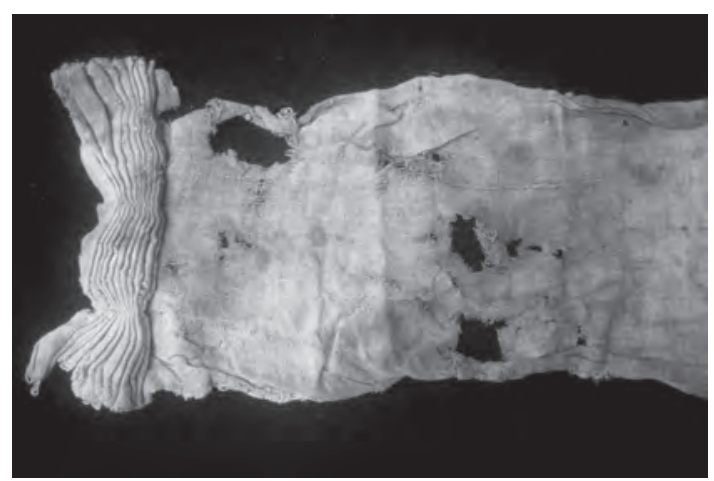

Figura 6. Un fragmento de canesú plisado de un vestido de mujer había sido cosido a una tela más grande (\#67), que fue hallado en el relleno de la tumba. El fragmento se muestra con la urdimbre orientada horizontalmente, como hubiera sido en el vestido original. \#56, SM 363.02.2037. 
de una urdimbre. Las urdimbres son Z-2S, las tramas son de un cabo hilado en S y las tramas suplementarias usadas para hacer las figuras son en su mayoría parejas o tríos de hilos hilados en Z. En los textiles Ychsma son comunes las variaciones en la torsión de los hilos en la misma pieza, y un número de brocados presentan esta combinación particular de estructuras de hilos (Frame s.f.). El ancho de un panel completo está presente, así como un centímetro de un panel similar, que es cosido a un lado (Fig. 7c). Una tira de tela marrón $(1 \times 50 \mathrm{~cm})$ fue cosida toscamente a una sección al otro lado del panel completo. Las costuras de este fragmento producen un plegado, en lugar de una costura plana. Esta última adición al panel del manto sugiere una muy específica, pero indeterminada, historia de uso, antes de que se arrancara el manto y se colocara el fragmento en la tumba.

El segundo manto está compuesto de, al menos, doce paneles de tela azul, marrón y beige donde se alternan escenas brocadas con cuadros llanos (\#67, Fig. 8a). El ancho original del manto estaba formado por seis o más paneles cosidos de lado a lado. El largo estaba formado por un par de paneles del mismo color. La escena de balsa representada puede referirse a la recolección de conchas spondylus,

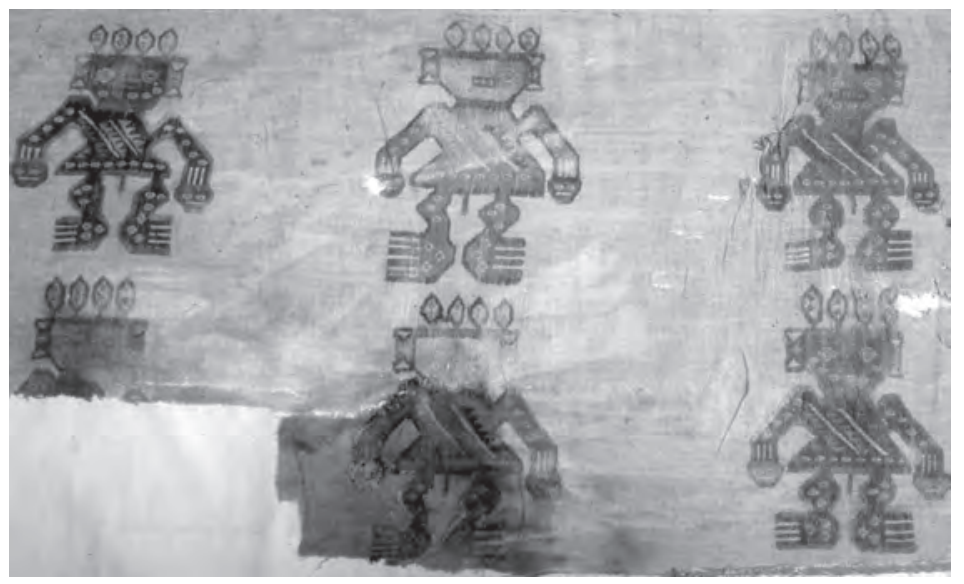

$a$

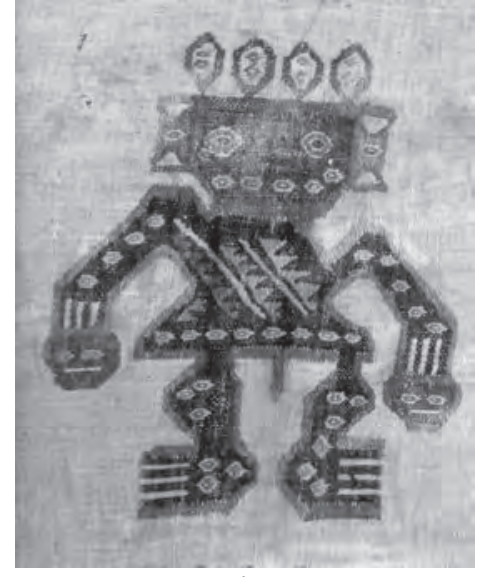

b

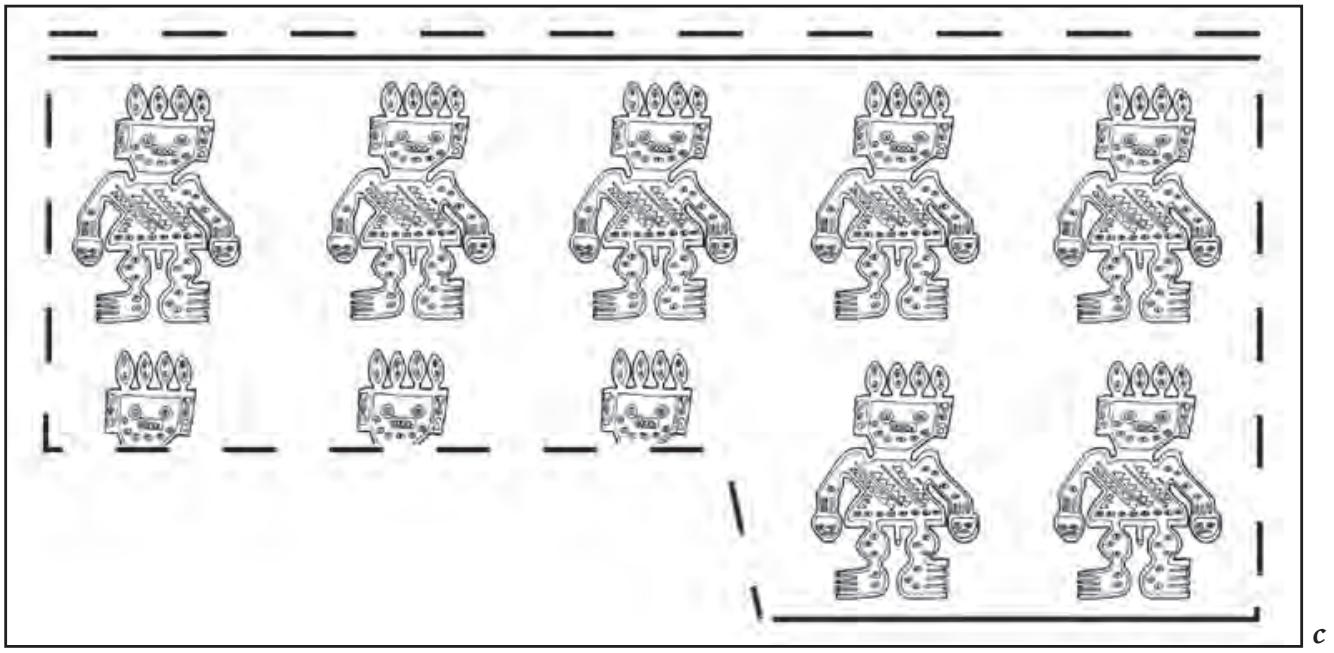

Figuras $7 a, b$ y $c$. Fragmento de un manto brocado, encontrado en el relleno de la tumba. El fragmento tiene dos hileras horizontales de personajes masculinos en un panel del manto original (a y c). Las figuras se muestran frontalmente y presentan una notable asimetría (b). 178 (la dirección de la urdimbre es horizontal) x $57 \mathrm{~cm}$. \#50, SM 363.02.1426. 

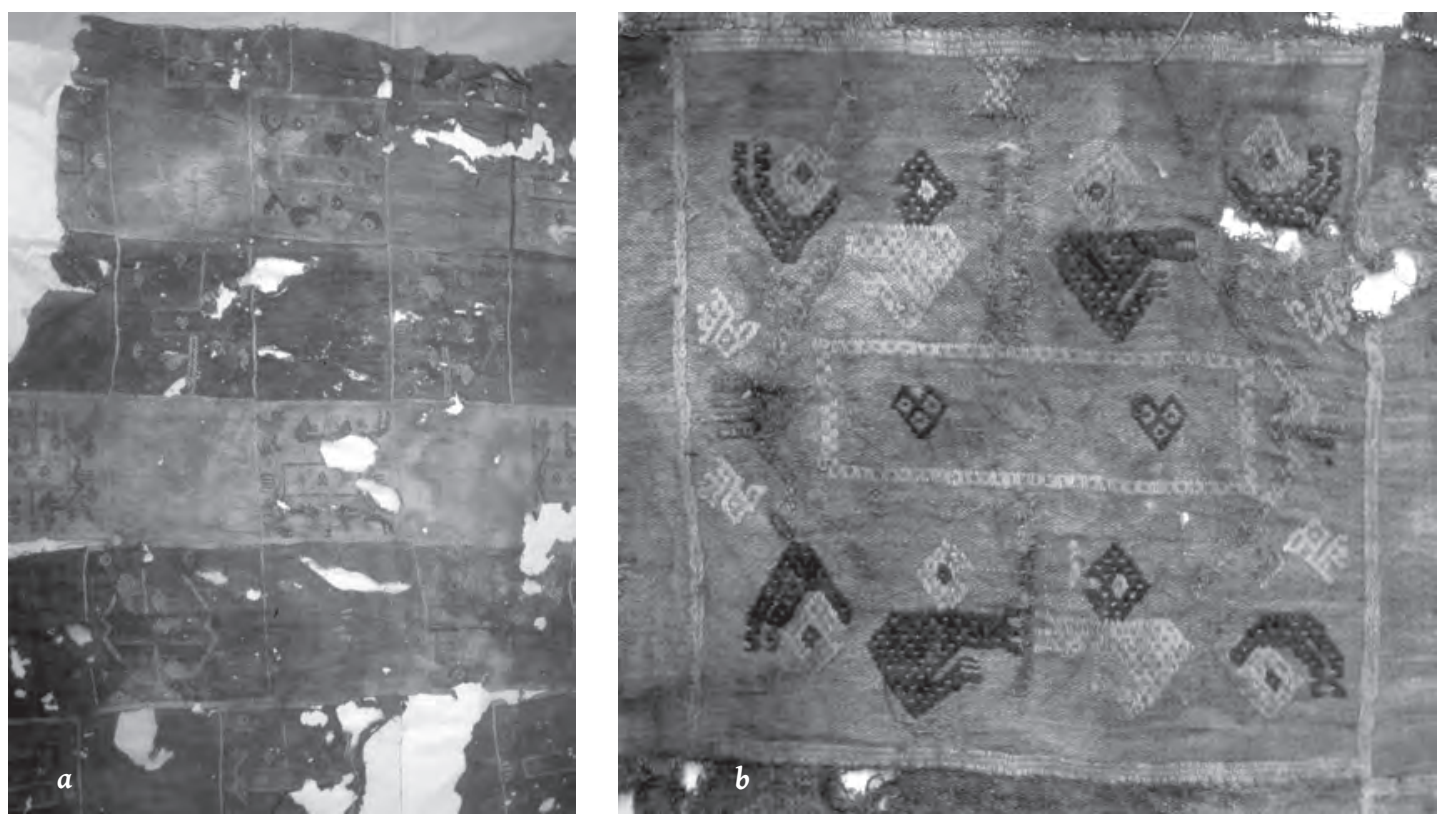

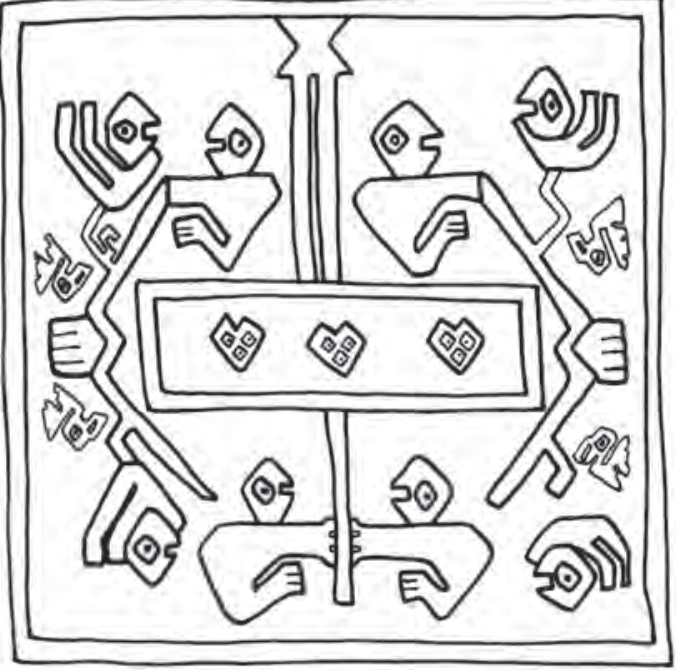

$c$

Figuras $8 a, b$ y $c$. Manto listado con colores alternados, que presentan escenas hechas con la técnica del brocado (a), fue encontrado en el relleno de la tumba junto con un fragmento de vestido de mujer (\#56) cosido a él. La escena en el manto muestra una balsa que incluye remadores, buceadores, aves y conchas spondylus ( $b$ y $c$ ). La dirección de la urdimbre es horizontal. $214 \times 103 \mathrm{~cm}$. \#67, SM 363.02.2120.

ya que tanto los buceadores y las conchas parecen estar representados a lo largo de los lados de la escena (Figs. $8 \mathrm{~b}$ y c). Los dos mantos fragmentados del relleno están elaborados con hilos de algodón, pero la estructura de este brocado fue configurada de manera diferente al telar del ejemplo anterior. Aquí las tramas flotan por encima de seis, cuatro o dos urdimbres y se sujetan por debajo de dos de ellas. Se añadieron bordes bordados para enmarcar la escena. El punto de cordoncillo ("stem stitch" en inglés) fue utilizada para delinear los lados de la escena, y el punto corrido ("running stitch") se empleó en los bordes superior e inferior. La estructura de los hilos es aún más variada, como las urdimbres que son tanto en Z-2S como en S-2Z y las tramas base son de un cabo hilado en Z o S. Las tramas suplementarias son predominantemente de un cabo hilado en $\mathrm{Z}$, al igual que la mayoría de los brocados. La misma escena se representa en un fragmento de brocado de Pachacamac (Schmidt 1910: Figura 25) y de Armatambo (excavación de Daniel Guerrero 1994), y una escena similar aparece en una tela pintada de Pachacamac (Schmidt 1910: Figura 24).

En la tumba, el fardo fue encontrado a $45 \mathrm{~cm}$ de profundidad, mientras que restos de dos cuyes o conejillos de Indias (Cavia porcellus) y partes de un feto humano fueron encontrados a $80 \mathrm{~cm}$ de profundidad (Vallejo 1988: 397). La presencia de la mujer sacrificada en la tumba ya se ha señalado. 
La forma original de los textiles en el relleno de la tumba puede ser reconocida en la mayoría de los casos, pero es interesante observar que muchos están arrancados o son piezas disgregadas de tipos estandares de prendas. Se sugieren varias posibilidades. Algunos tejidos pudieron haber sido expuestos en las paredes, para luego ser arrancados y usados en el entierro. O tal vez fueron recuperados de otros contextos, incluyendo entierros, y re-utilizados como ofrendas en esta tumba. Los textiles en el interior del fardo funerario incluyen algunos fragmentos y fusiones de fragmentos que pueden haber tenido una similar, pero indeterminada, historia de uso.

\section{Apertura del FARdo fUnerario de ARMATAmbo}

Los textiles en el interior del fardo incluían varias prendas de vestir completas que vistieron el cuerpo del difunto. Grandes telas de envoltorio (o grandes fragmentos) predominaron entre las capas externas del fardo. Las telas de envoltorio eran sobre todo de forma rectangular, confeccionadas a partir de tres paneles de tela. Tienen hasta casi $400 \mathrm{~cm}$ de largo por $200 \mathrm{~cm}$ de ancho, y muestran varias técnicas. Los paneles de los mantos usualmente tienen un ancho de telar de $60 \mathrm{~cm}$, que es un tamaño conveniente para tejer en el telar de cintura. Aunque estas telas se conocen como "mantos", su tamaño puede indicar un uso diferente al de prenda de vestir. Amarres de tela de algodón sin teñir son anudados alrededor del fardo a intervalos, separando las cinco capas de telas de envoltorio o de ropa. Todos los amarres son de fibra de algodón blanco y ligamento llano. Fragmentos más pequeños e irregulares de tela decorada abundan en todo el fardo, los cuales pueden haber sido utilizados para aumentar el tamaño o cambiar la forma del mismo. A diferencia de muchos de los fardos del Horizonte Tardío excavados en el valle del Rímac, este fardo no tenía una gruesa capa de fibra de algodón sin procesar justo debajo de la tela de envoltorio exterior (Cock 2002; Frame et al. 2004), ni tampoco tienen capas de hojas o de otro material vegetal (Haun y Cock 2010: 203).

\section{Primera Capa}

El tejido que fue colocado en la parte externa del fardo fue un manto incompleto con algo más que un panel, el cual fue doblado y dispuesto encima del fardo. Cosido al fragmento del manto van dos parches rectangulares de tapiz y dos bordes de tapiz con flecos ubicados en los extremos (\#1, Fig. 9). Las características técnicas y dimensiones sugieren que este manto originalmente tuvo tres paneles con dimensiones totales de aproximadamente 335 x $195 \mathrm{~cm}$ y que tenía alrededor de veintiún parches en tapiz. Los parches en tapiz, que fueron tejidos en tonos naturales de algodón, representan un animal con caracteres antropomorfos que lleva un tocado en forma de medialuna con la barbilla rodeada por una banda, mientras que en el borde inferior se representan aves también con rasgos antropomorfos. La torsión de las urdimbres es $\mathrm{Z}-2 \mathrm{~S}$, pero es variable en las tramas. Las tramas de la tela de base son de un cabo hilado en S, mientras que las tramas utilizadas para los parches en tapiz, bordes y flecos

Figura 9. El fragmento de manto, que fue colocado en la parte externa del fardo, tenía parches y bordes en tapiz cosidos. Cinco dos dentro del fardo. $340 \times 65 \mathrm{~cm}$. \#1, SM 363.02.2129.

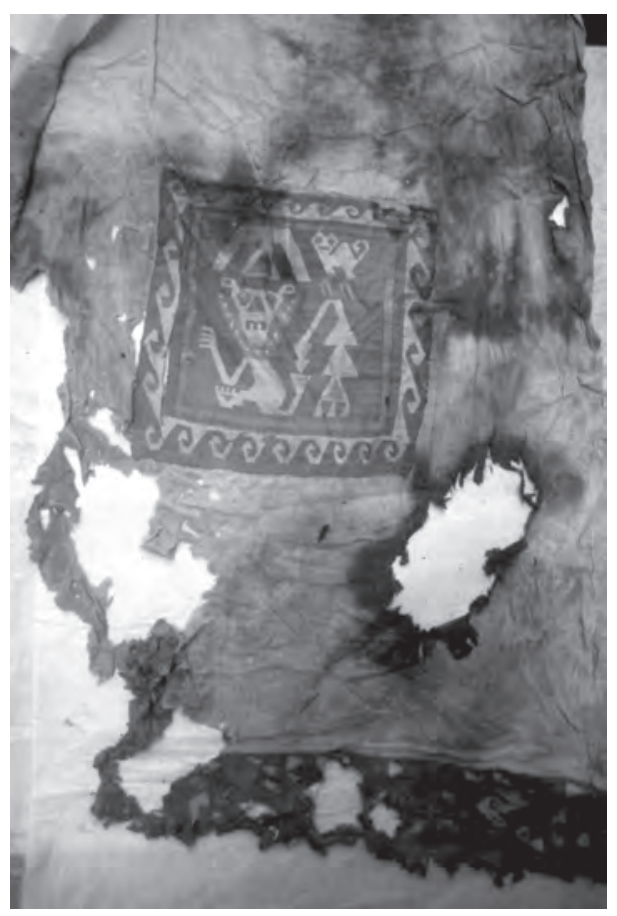




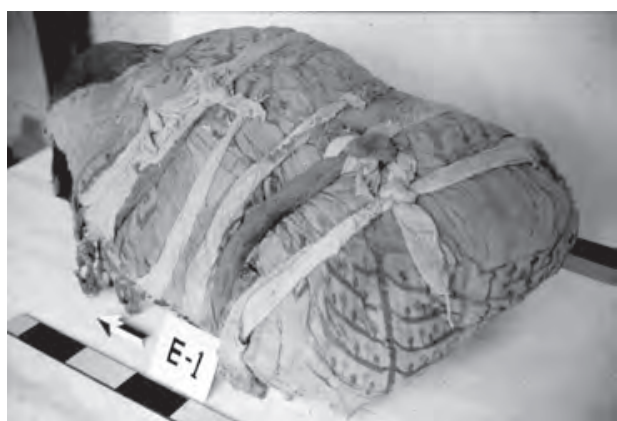

$a$

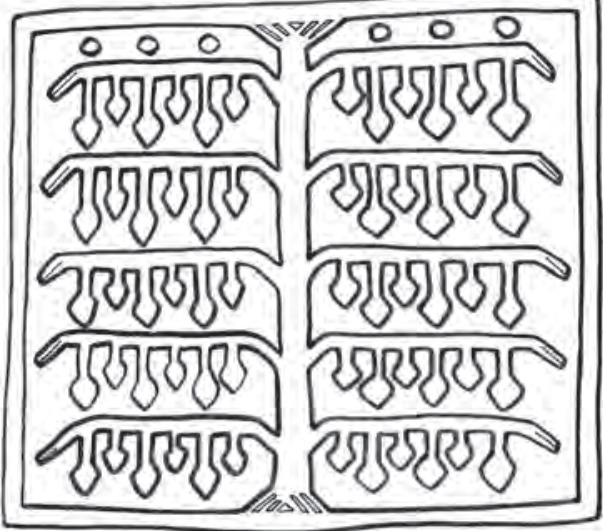

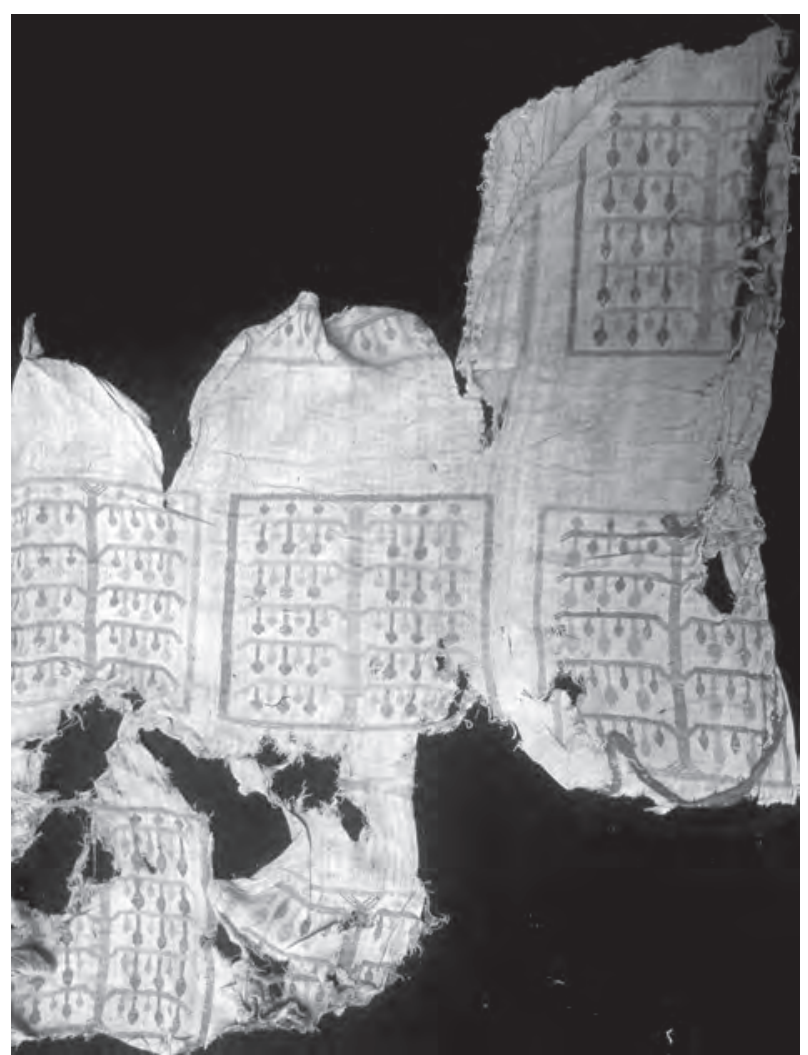

b

Figuras 10 a, b y c. El primero de los cuatro conjuntos de amarres (\# 3a-3g) aseguran un paño envoltorio hecho en la técnica del brocado (a). Los árboles con frutos están enmarcados (c) y se repiten en pares de columnas en cada panel del gran fragmento de manto (b). $167 \times 160 \mathrm{~cm}$. \#4, SM 363.02.1996.

Figura 10a fotografiado por Mario Ruales 1982.

son de un cabo hilado en Z. Las características técnicas de este textil, incluida la tapicería de algodón, la aplicación de los parches de tapicería y la variabilidad en la dirección de la torsión de las tramas, son típicos de los textiles Ychsma. Aspectos de la iconografía, especialmente el tocado aplanado en media luna y los triángulos en la cola de la figura, parecen influenciadas por un estilo del norte, posiblemente Chimú (compárese con Rowe 1984: Figuras 129 y 30).

Una estera tejida con tallos de fibra vegetal cubre el exterior del fardo (\#2, Díaz y Vallejo 2005: Figura 7; Vallejo 1988: Figura 6). El borde de inicio indica que los tallos (Scirpus riparius) fueron doblados por la mitad, y entrecruzados diagonalmente con los tallos adyacentes, antes de ser aseguradas con cuatro filas de encordado ("twining") de dos tramas en la dirección Z. A lo largo del resto de la estera se repiten parejas de las filas encordadas a intervalos espaciados.

\section{Segunda Capa}

Debajo de la estera se encontró un conjunto de amarres o lazos que sirvieron para sujetar los paños envoltorios de la segunda capa (\#3 a-g, Fig. 10a). La tela exterior era un manto de tres paneles que tiene una imagen en brocado de un árbol estilizado que se repite en cada panel (\#4, Figs. 10b y c). Parte de los tres paneles están presentes, incluyendo secciones de los orillos de urdimbre en un extremo. Otro fragmento de brocado con una imagen similar fue encontrado en el depósito (SM 363.02.2119, 130 x $128 \mathrm{~cm}$ ). 


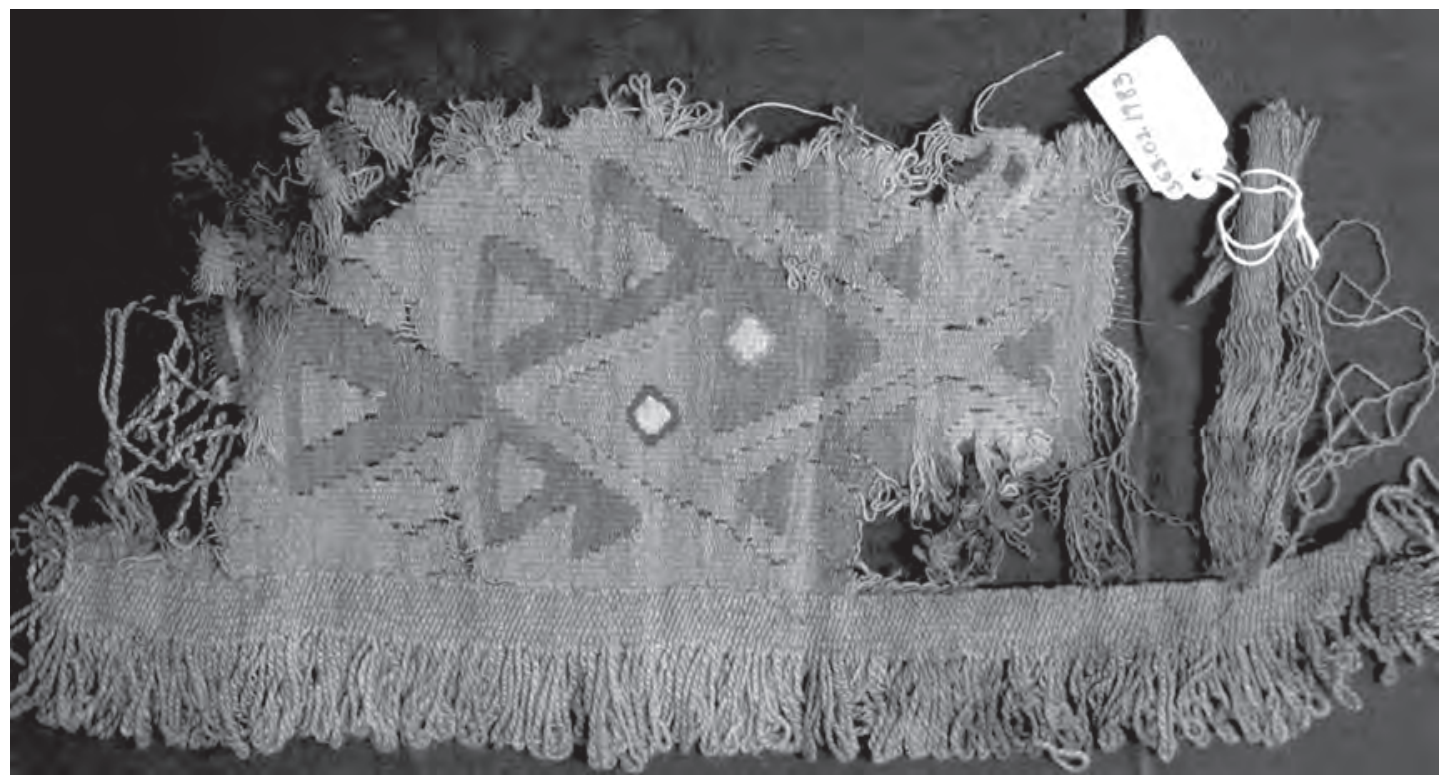

Figura 11. Un borde en tapiz con un diseño de peces entrelazados fue uno de los fragmentos encontrados en el segundo nivel del fardo. 28 (la dirección de la urdimbre es horizontal) x $14 \mathrm{~cm}$. \#6a, SM 363.02.1983.

Es probable, pero no seguro 9 , que sea un fragmento de este manto. El manto está elaborado con algodón de colores naturales, las urdimbres y tramas del tejido base están retorcidos en Z-2S. Las tramas suplementarias del brocado son de un cabo hilado en $\mathrm{Z}$, y se utilizan pareadas. Al igual que el manto con las figuras masculinas (Fig. 7), el brocado es el tipo más común, donde las tramas suplementarias flotan por encima de cinco urdimbres, y se sujetan por debajo de una urdimbre. En la iconografía Ychma es notable la presencia de plantas (Fig. 10c), incluyendo ejemplos donde las aves o monos comen frutos y plantas.

Varios fragmentos, algunos pequeños y de vívidas imágenes, se han colocado en la segunda capa del fardo, por debajo de los amarres y el manto. Una pequeña pieza de un borde en tapiz (\#6a, Fig. 11) y parte de un pez en tapiz (\#6b) de otro manto (\#12) se encontraban entre ellos. El fragmento de borde en tapiz, tejido con tramas de fibra de camélido, está teñido con brillantes colores, una característica que se encuentra en una minoría de tapices Ychsma. Los textiles en este nivel incluyen un paño grueso tejido de algodón blanco natural, con una mancha de tinte púrpura (\#7), posiblemente derivado de un molusco caracol (Plicopurpura patula pansa gould) que vive en las zonas intermareales en algunas partes de la costa.

Otro fragmento tiene hileras de plumas de color rojo, amarillo y azul iridiscente cosidas a la tela base (\#8, Fig. 12). Las plumas azules y rojas se utilizan juntas para elaborar diseños de bandas que no están claramente delineadas, mientras que las plumas amarillas cubren el campo de arriba y abajo. La posición de la banda y el tamaño de los fragmentos sugieren que esta era parte de un tabardo de plumas, una prenda que cubre el torso y tiene lazos en lugar de costuras laterales, y que se distribuyó ampliamente en el Horizonte Tardío. La tela base consta de tres estrechos paneles cosidos juntos, y todos tienen el mismo patrón en la dirección de la torsión de la urdimbre (Z-2S) y trama (un cabo hilado en Z). Dos fragmentos rotos, uno en brocado y otro un tejido con plumas (\#8 a y b, Fig. 13), han

9 El segundo fragmento de una tela similar ingresa como procedente del Sector D2, sección D, en el inventario de los arqueólogos, pero no hay número de registro del fardo funerario. El textil con \#5 no fue ubicado en el depósito o en los diversos registros consultados, por lo tanto, es posible que al segundo fragmento del manto \#4 le fue asignado este número. 


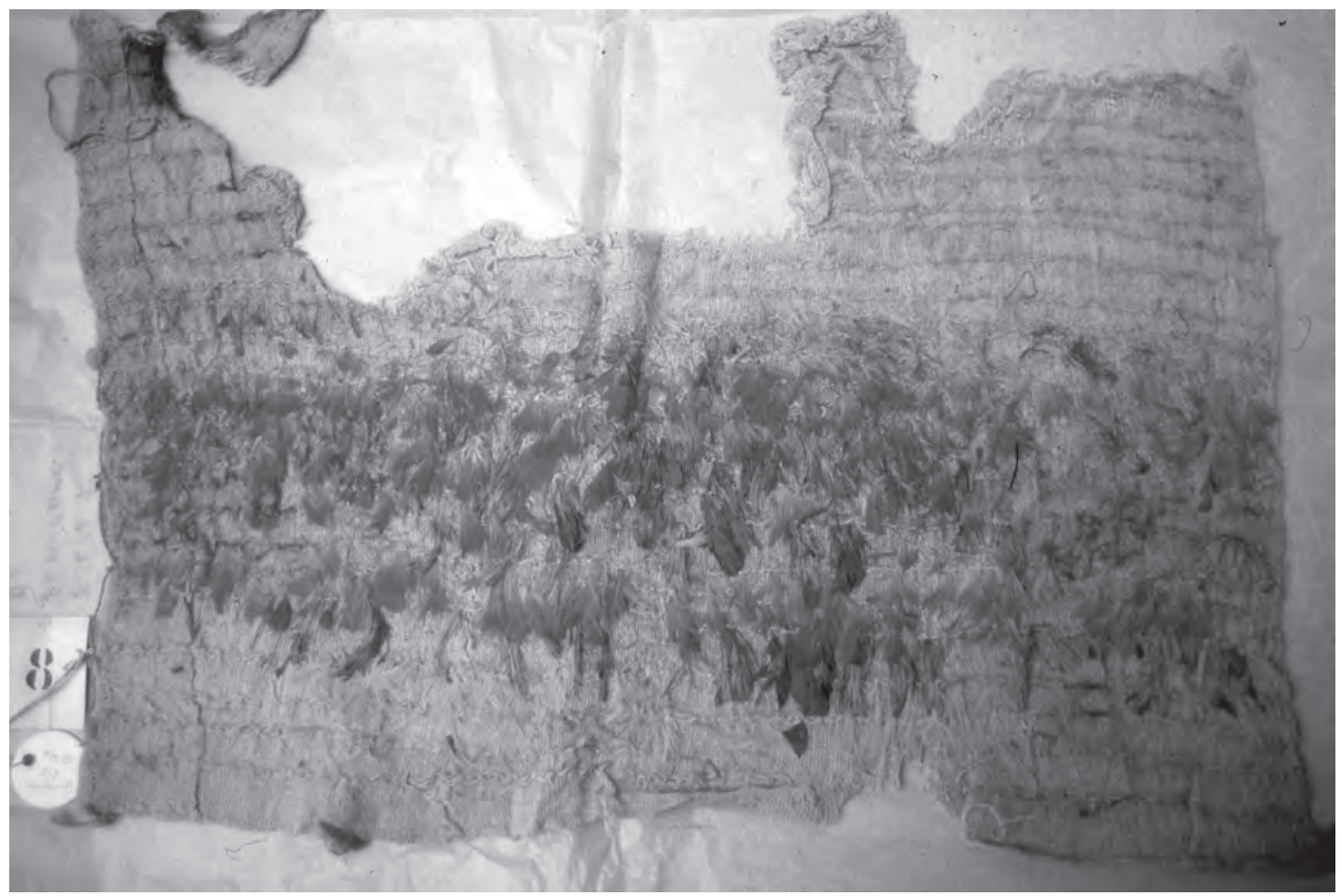

Figura 12. Un fragmento de tela decorada con plumas que posiblemente fue parte de un tabardo o túnica abierta. Corresponde a la segunda capa del fardo, junto con otros fragmentos. $38 \times 56 \mathrm{~cm}$. \#8, SM 363.02.2127.

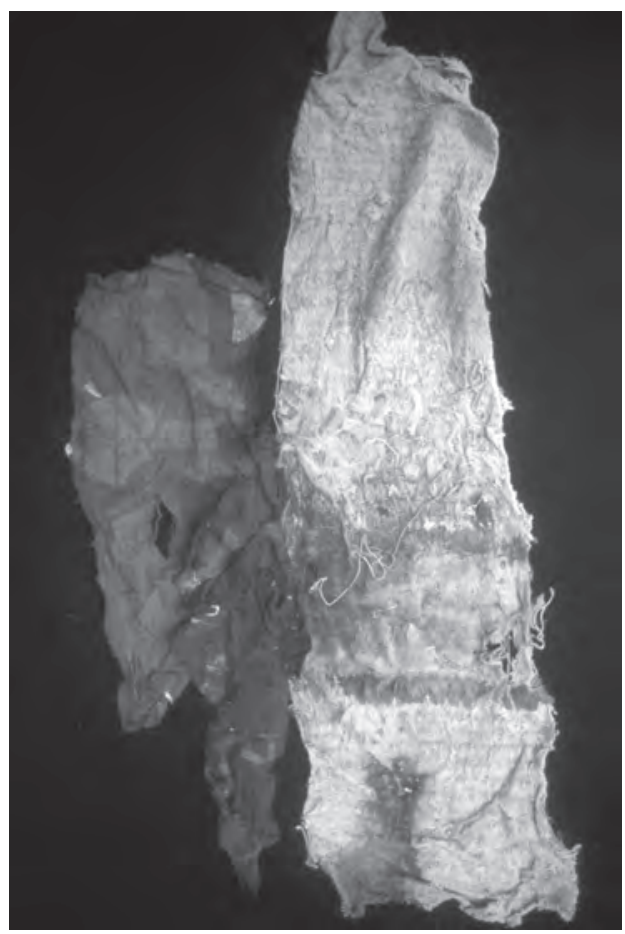

sido cosidos juntos mediante puntadas burdas. El fragmento en brocado muestra la estructura estándar (con tramas suplementarias que flotan por encima de cinco urdimbres y se sujetan por debajo de una urdimbre), y el color y la dirección de la torsión de la mayoría de los mantos en brocado. La imagen parcial del brocado podría ser una mano de una gran figura con un apéndice serpentino adjunto. El otro fragmento pudo haber sido parte de otro tabardo de plumas. La condición de este grupo de textiles sugiere que ya era fragmentaria cuando se coloca en el fardo y muy posiblemente hayan sido extraídos como fragmentos de otros contextos.

También en este nivel fue colocado un conglomerado de telas de ligamento llano en la zona del pecho (\#9a-i). Algunas prendas de algodón que están más o menos completas se encuentran entre ellos. Un paño sin decoración de tres paneles (\#9b, $108 \times 61 \mathrm{~cm}, \mathrm{SM} 363.02 .2083)$ y una camisa corta sin mangas (\#9e, 34 x $83 \mathrm{~cm}$, SM 363.02.2082)

Figura 13. Los fragmentos rotos en la segunda capa incluían un pedazo de tela con brocado y un trozo de plumario deteriorado que habían sido cosidas juntas toscamente. \#8a y b, SM 363.02.2079. 
están hechos de algodón blanco natural. La camisa ha sido confeccionada a partir de dos paneles doblados a la altura del hombro y con costuras de unión en la parte central y en los lados. Un segundo paño de tres paneles (\#9a, 124 x $61 \mathrm{~cm}$, SM 363.02.2081) es inusual debido a que un panel es más largo que los otros dos. Las diferentes combinaciones de torsión para la urdimbre y la trama están presentes en cada uno de los paneles. Las urdimbres, por ejemplo, son Z-2S (la dirección de la torsión del hilo más común para la confección de las urdimbres en los tejidos Ychsma), S-2Z, o de un solo cabo hilado en Z, mientras que las tramas son en un solo cabo hilado en Z o S. Aunque la variabilidad en la construcción de hilos es común entre los textiles Ychsma, este ejemplo es extremo.

Otros textiles en el ligamento llano de este grupo incluyen un paño rectangular de color blanco con listas de urdimbres marrones en el borde (\#9f, $62 \mathrm{~cm} \mathrm{x} \mathrm{55,} \mathrm{SM} \mathrm{363.02.2086),} \mathrm{un} \mathrm{fragmento} \mathrm{de} \mathrm{tela} \mathrm{de} \mathrm{color}$ beige carbonizado (\#9g, SM 363.02.2080), un fragmento ajedrezado con urdimbres y tramas en blanco y marrón (\#9h, 42 x 17 cm, SM 363.02.1984), y un grueso tejido completo de tela blanca (\# 9i, 32 x $23 \mathrm{~cm}$, SM 363.02.2087). A pesar de que en general son de calidad deficiente, los textiles de este grupo se caracterizan por la variabilidad de la torsión en los hilos. La mayoría de los hilos son Z-2S o de un cabo hilado en Z, pero hilos de un cabo hilado en $S$ también están presentes en este grupo ${ }^{10}$.

Por debajo de la diversidad de fragmentos y prendas de vestir de esta capa hay un manto marrón formado por tres paneles que envolvía completamente el fardo. Presenta un solo motivo de círculos concéntricos realizado con sartas de plumas de tres colores que fueron cosidas sobre la tela (\#10, Fig. 14). La sección central del manto, justo por encima del círculo, se ha perdido debido al deterioro, pero algunas partes de todos los orillos se conservan. Como la mayoría de mantos, los tres paneles tienen un ancho de $60 \mathrm{~cm}$ cada uno, pero la longitud sólo puede ser estimada por la sección que falta. La estructura de este paño de algodón es ligamento llano con un ligero predominio de urdimbres. Las urdimbres son Z-2S y las tramas son de un cabo en Z y S. El motivo del círculo es inusual y la ubicación asimétrica de este único motivo lo es aún más.

Un fragmento brocado con un gran pez (\# 10a, Fig. 15a) fue adjuntado al manto con costuras gruesas cerca del círculo de plumas. El motivo de pescado ocupa todo el ancho de un panel de $60 \mathrm{~cm}$, probablemente uno de los tres paneles de un manto grande. Por encima y por debajo del pez hay fragmentos de otros peces en combinaciones de diferentes colores. A juzgar por los mantos completos y las dimensiones de este fragmento, originalmente el pez grande pudo haberse repetido 18 veces con una alternancia diagonal de colores en el manto original. La fibra (algodón), la estructura de brocado (las tramas suplementarias que flotan por encima de cinco urdimbres y se sujetan por debajo de una urdimbre) y la torsión de los hilos (Z-2S para las urdimbres de la tela base y un cabo hilado en Z para las tramas suplementarias pareadas) son conformes con las características técnicas más recurrentes de los mantos brocados de Ychsma (Frame s.f.). Las tramas de la tela base son Z-2S en este ejemplo. La imagen muestra la interacción entre los motivos, una característica notable de algunas imágenes Ychsma, donde las aves, el pescado y los crustáceos se muestran con frecuencia en actitud de comer o ser comidos. Un cuadrúpedo con cola se muestra en el vientre del pez, utilizando la convención artística de una vista de rayos-X (Fig. 15b).

\section{Tercera Capa}

El nivel tres del fardo se indica por un amarre de algodón anudado (\#11, SM 363.02.2075). Debajo del amarre, hacia un lado del cuerpo, se encontró la mitad de un manto con parches en tapiz en forma de peces (\#12, Fig. 16a). Un panel completo de la tela base de algodón y la mitad de otro panel fueron teñidos, o posiblemente pigmentados, en un tono amarillo. Cinco peces enteros y cuatro incompletos permanecen, junto a bordes decorativos en tapiz con diseños de aves y de plumas. Probablemente el

10 Los especimenes que corresponden a los números $9 \mathrm{c}$ y $9 \mathrm{~d}$ no se encontraban en el depósito, ni en ninguna de las listas o documentos consultados. 


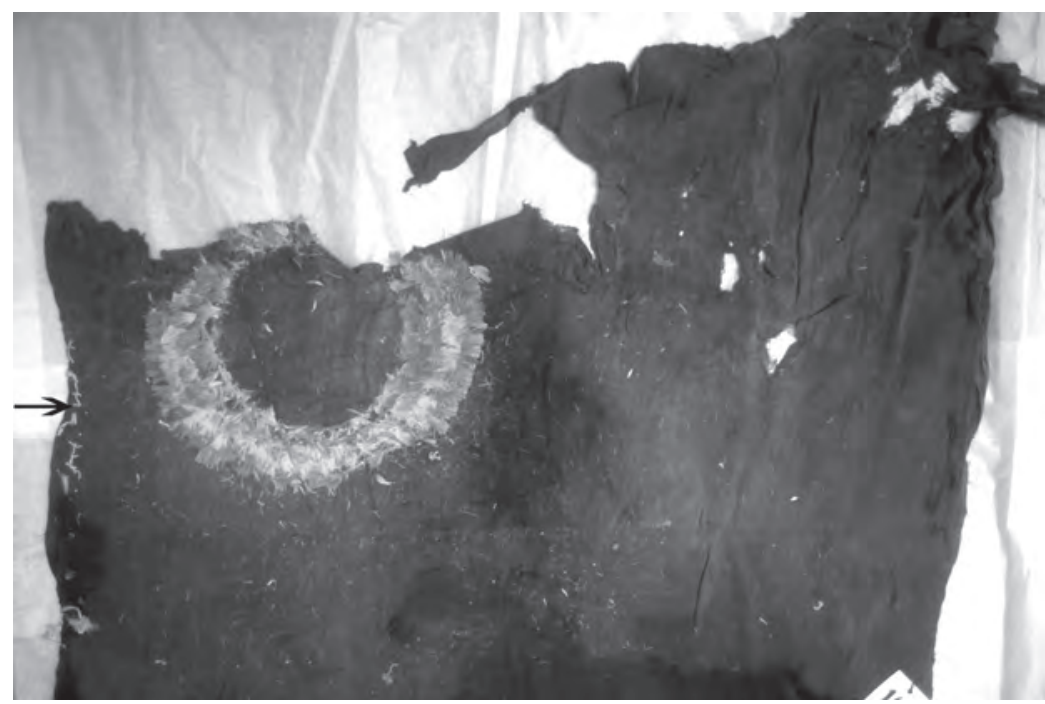

Figura 14. Un manto de tres paneles en la capa dos, presenta un motivo de círculos concéntricos formados con plumas rojas, amarillas y azules. La flecha a la izquierda indica donde fue cosido el fragmento de brocado al manto (Figura 15a). >280 x $180 \mathrm{~cm}$. \#10, SM 363.02.2123.
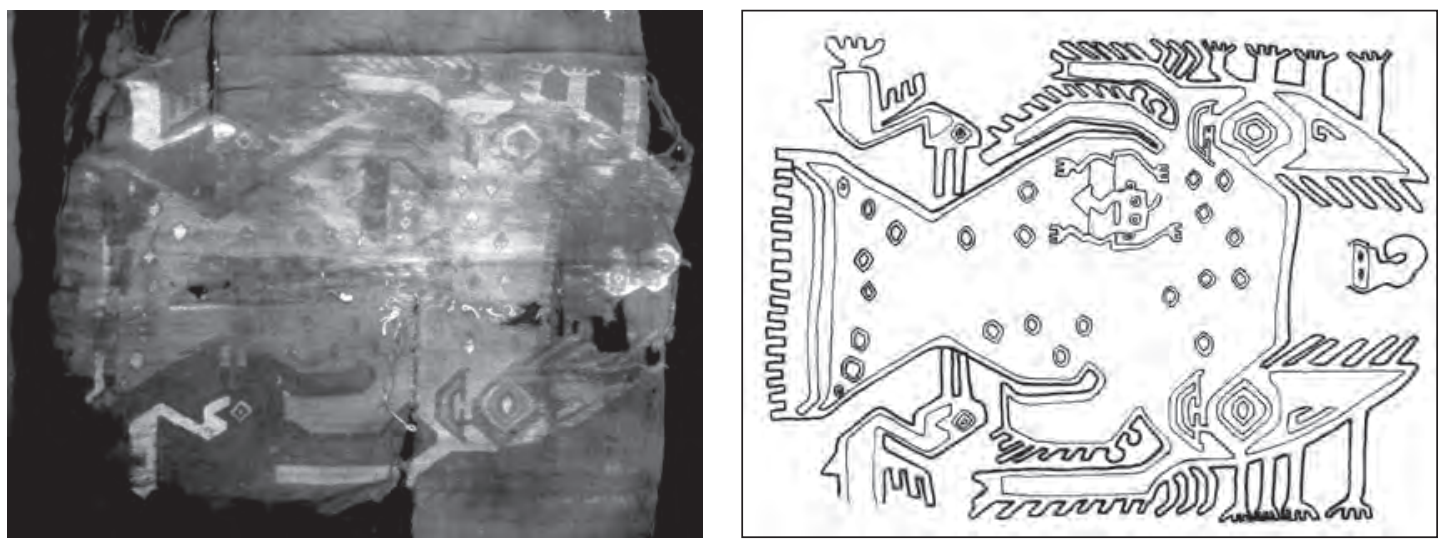

Figuras 15 a y b. Un fragmento de brocado (a), que presenta un pez ingiriendo a un crustáceo mientras que aves picotean su cuerpo (b), estaba cosido al manto \#10 (nótese las puntadas gruesas al lado izquierdo de la figura 14, indicada por la flecha). $82 \times 60 \mathrm{~cm}$. \#10a, SM 363.02.2126.

manto originalmente tenía tres paneles y catorce aplicaciones de peces. Las adiciones en tapiz, que incluyen los bordes en los extremos, son de algodón, y fueron tejidos en colores naturales y teñidos (Figs. 16 b y c). En todo el fragmento de manto, la construcción del hilo es Z-2S, con la excepción de las tramas de tapiz que son de un cabo hilado en $\mathrm{Z}$. Todos los bordes de los peces están muy bien acabados, ya sea por anudar los hilos o zurcirlos de nuevo después de haber sido cortados. Los nudos que amarran las urdimbres cortadas se ocultan dentro de un ribete tubular tejido en el borde. El acabado de la forma tan compleja es impresionante, puesto que todos los bordes tienen la apariencia de orillos. Ambas figuras de peces y aves son comunes en la iconografía Ychsma, y las aletas de este pez se asemejan a las alas de una ave.

Un segundo amarre anudado (\#13, SM 363.02.2137), además del \#11, sujetan dos grandes paños envoltorios de la tercera capa del fardo. Uno de ellos es un manto amarillo de tres paneles que muestra un patrón de aves volando (\#14, Fig. 17a). Las aves marrón oscuro son bilateralmente simétricas y 

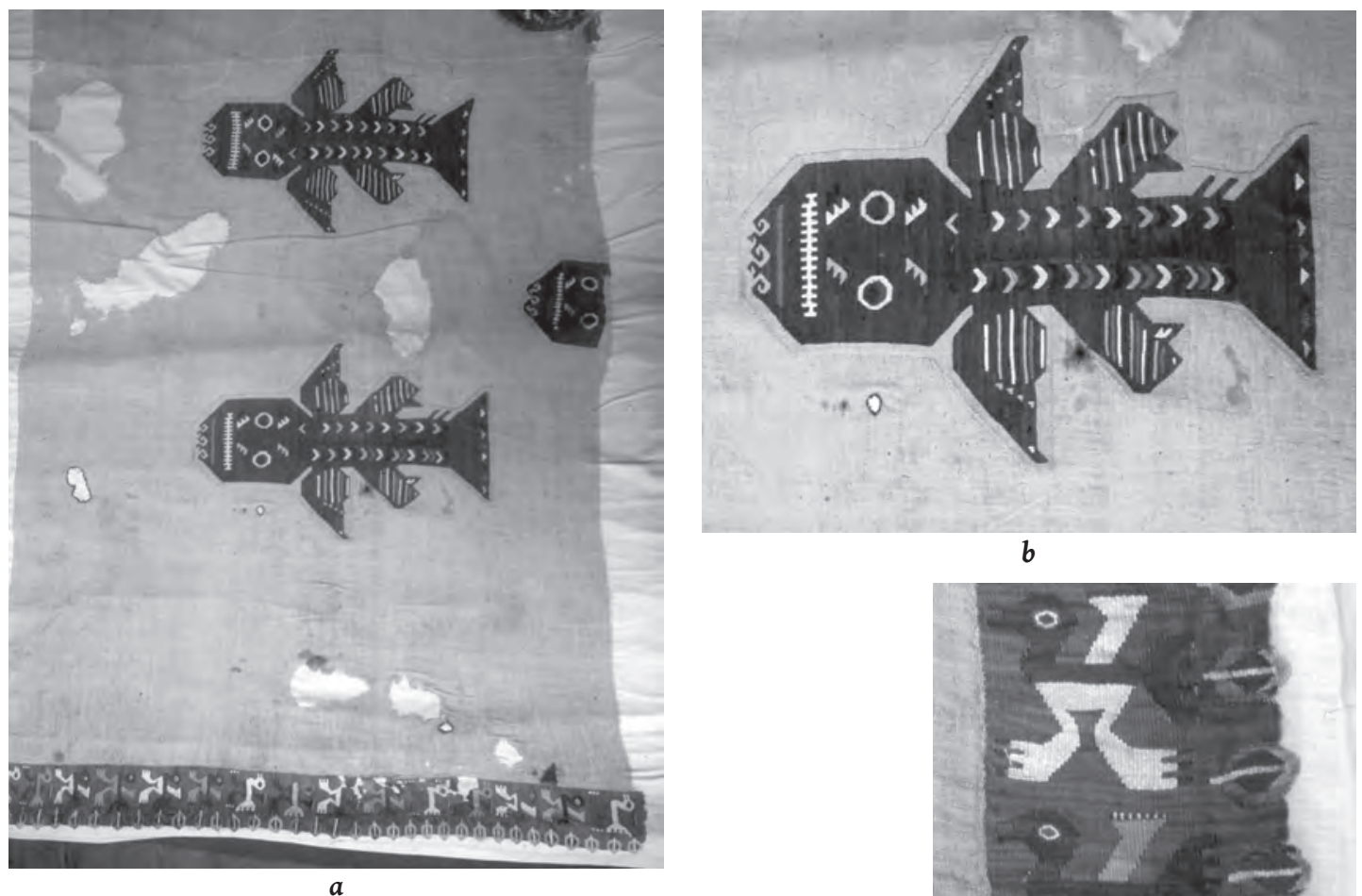

Figuras 16 a b y c. La capa tres del fardo contenía la mitad de un manto (a) con parches de peces y los bordes cosidos a él (b y c). El pez en tapiz está tejido y acabado en todos sus bordes (b). Posteriormente, fue cosido al manto de algodón amarillo. $383 \times 105 \mathrm{~cm}$; parche de pez: 48 (la dirección de la urdimbre es horizontal) x $36 \mathrm{~cm}$. \#12, SM 363.02.1427.

se repiten en la simetría conocida como "traslación" (es decir, repetición exacta), que es un patrón simétrico común en los mantos en brocado y/o tapiz Ychsma. Sin embargo, este manto se diferencia en varios aspectos de la mayoría de los mantos Ychsma. Las figuras son más pequeñas, más numerosas y se repiten en alineación alterna. Además, tanto las urdimbres y tramas de la tela base son de un cabo hilado en S y las aves son bordadas, en lugar de brocado (Fig. 17b). Pares de hilos hilados en $\mathrm{Z}$ fueron insertados sobre la tela base con una aguja a un ritmo similar al de la mayoría de los brocados Ychsma (flotando por encima de cinco urdimbres y sujetando por abajo de una urdimbre). A pesar de la semejanza con los brocados, los motivos son definitivamente bordados porque algunos de ellos atraviesan la costura entre dos paneles del tejido. Las "alas" y las

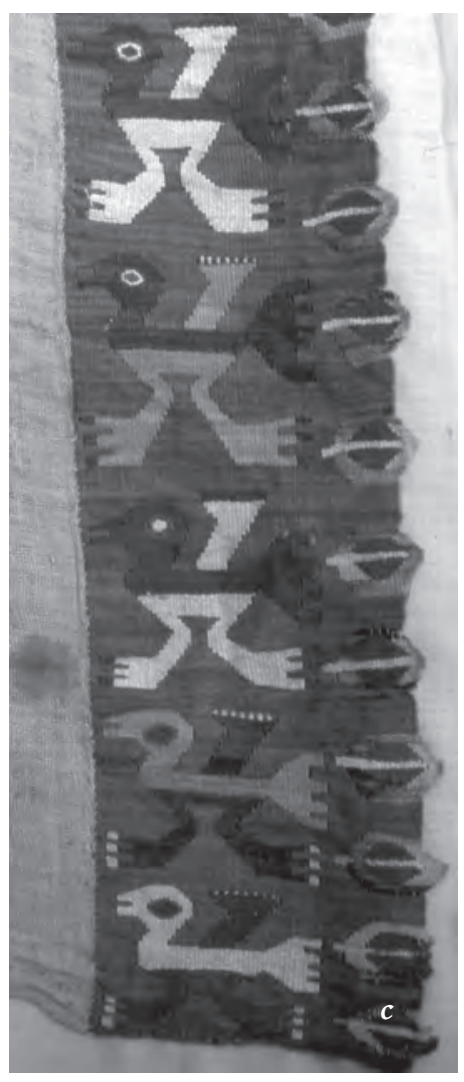
patas de las aves que vuelan se asemejan a los apéndices o aletas de los mamíferos marinos, aunque el pico y la cola son de ave. Esta mezcla de atributos de los distintos animales es probablemente intencionada, y producen una ambigüedad interesante: ¿es la acción de volar o nadar?, ¿la tela de fondo es el mar o el cielo? No hay evidencias de los bordes finales de este gran manto de algodón, que originalmente tiene un ancho de $198 \mathrm{~cm}$ y un largo de casi $400 \mathrm{~cm}$.

El otro paño envoltorio de esta capa, es una tela de fondo amarillo con parches rectangulares en tapiz (\#15, Fig. 18a). Se conservan dos fragmentos grandes del manto de tres paneles, incluyen 

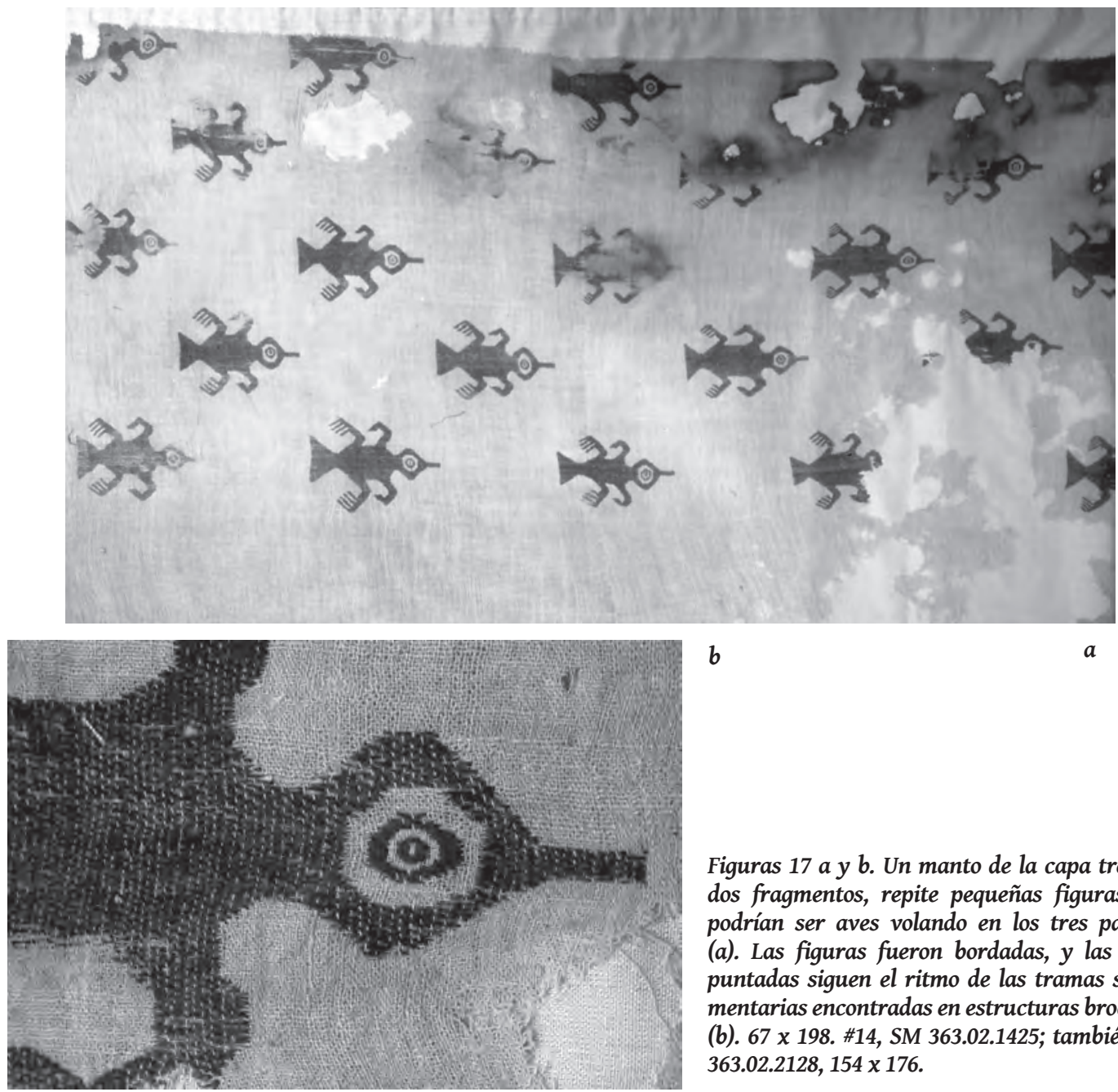

$b$

$a$

un borde en tapiz y una banda con flecos. Los hilos de fibra de camélido se usan solo para las tramas de color rojo brillante que se encuentran en el borde y los flecos. Las urdimbres de la tela base, los parches, los bordes y la banda marginal son consistentemente Z-2S, pero las tramas en la tela base son de un cabo hilado en S, de un cabo hilado en $\mathrm{Z}$ en los parches, y una mezcla de estructuras de hilos en los bordes. Los parches, como los tapices Ychsma en general, se tejen en el ligamento de tapiz ranurado. Los trabados ensamblados, a veces nombrados "cola de paloma" o "dove-tail" en inglés, son utilizados ocasionalmente para cerrar las largas ranuras de tapiz, o más comúnmente, las costuras. El borde final de los parches en tapiz tiene un ribete de forma tubular en el que se ocultan las urdimbres cortadas y anudadas. El manto originalmente pudo haber tenido 19 (seis, siete, seis) parches dispuestos en los tres paneles ${ }^{11}$. Aves de pie (Fig. 18b), en lugar de volar o nadar, se repiten en los parches y el borde. La figura de gancho que se repite en los bordes de los parches puede referirse a las olas del mar encrespado.

11 El número de parches no pudieron ser verificados debido a la complejidad del plegado de los fragmentos y la falta de espacio en el depósito. 


\section{Cuarta Capa}

Cuatro amarres de tela de algodón (\# 16, SM 363.02.2075, \# 17, SM 363.02.2144, \# 19, SM 363.02.2138, y \#20 a y b, SM 363.02.2147) aseguran los paños envoltorios de la cuarta capa del fardo. El primer amarre se encuentra arrugado y anudado. El segundo, que estaba abierto, era una tela blanca de tres paneles con dimensiones de 125 x $60 \mathrm{~cm}$. En este paño de tejido abierto, los hilos de urdimbre y trama son de un cabo hilado en Z. El tercero es un fragmento de dos paneles tejidos y cosidos entre sí que miden 80 x $45 \mathrm{~cm}$. Ambos hilos de urdimbre y trama son de un cabo hilado en Z. El último amarre, que consta de dos piezas, es de $104 \mathrm{~cm}$ más $83 \mathrm{~cm}$ de longitud y $16 \mathrm{~cm}$ de ancho (aplanado). La construcción del hilo para ambos fragmentos es Z-2S para las urdimbres y las tramas son de un cabo hilado en Z.

El primer tejido de la cuarta capa es un gran fragmento de manto en brocado, de tres paneles, en que se repite una figura que parece ser una planta con caracteres zoomorfos (\#18, Fig. 19a). Zarcillos en espiral están unidos a la figura, que se compone de dos serpientes cada una con dos cabezas, más una cabeza en la parte superior de la figura (Fig. 19b). La figura grande, $50 \times 60 \mathrm{~cm}$, que se repite nueve veces en el fragmento existente, es única en el repertorio iconográfico Ychsma reunido hasta ahora. Tres combinaciones diferentes de colores se exhiben en las figuras, y los que son del mismo color se encuentran alineados en diagonal sobre los tres paneles. Este es el patrón más común de alternancia cromática en los textiles Ychsma. Una característica inusual es el cambio de colores de la tela base. Algunas áreas tienen tramas de color café claro, tramas marrones o tramas de dos colores alternados. Algunas de las tramas se han deteriorado, dejando rasgaduras de tela en algunas áreas (ver los bordes derecho e izquierdo de la Fig. 19a). Este manto coincide con la mayoría de los mantos brocados Ychsma en cuanto al hilado y el tipo de brocado. Estrechas franjas de tela han sido burdamente cosidas al orillo de trama y partes de orillo de urdimbre. Estas adiciones desconcertantes indican una particular, pero desconocida, historia antes de ser utilizado como un paño de envoltorio en el fardo. El manto completo pudo haber tenido alrededor de un tercio más de tamaño que el fragmento superviviente, que es de $250 \mathrm{~cm}$ de largo.

Por debajo del final de los amarres (\#19 y \#20 a y b), cerca del pie del fardo, había un fragmento de brocado de algodón con un patrón ajedrezado de rectángulos llanos y rectángulos con dibujos (\# 21, Fig. 20a). Rombos con bordes aserrados se repiten dentro de las celdas de una red hexagonal en los rectángulos con dibujos (Fig. 20b). El patrón se teje en una estructura de brocado menos común, donde las tramas suplementarias flotan por encima de un número par de urdimbres y se sujetan por debajo de dos urdimbres. La tela de la base es el ligamento llano de urdimbre predominante. Las urdimbres son Z-2S, las tramas de la base de un cabo hilado en S, y las tramas de brocado son de un cabo hilado en Z, usados en pares. El ángulo agudo de los bordes dentados que delinean el diamante sugieren un origen norteño para el motivo (compárese con Rowe 1992: Figura 14). El patrón ajedrezado puede indicar una influencia inca ${ }^{12}$. El fragmento ha sido rasgado en todos los lados antes de que fuera colocado en el paquete, por lo que la forma original de la tela no puede ser comprobada.

La figura más detallada de todas se repite en un gran fragmento de manto en brocado de tres paneles, que era el siguiente paño envoltorio en la cuarta capa del paquete. La figura lleva un tocado de media luna creciente con la barbilla rodeada por una banda (\#22, Fig. 21a), que son una reminiscencia de las formas de tocado representados en textiles de los estilos norteños, como Sicán. La figura está asociada con una estructura escalonada, tal vez una plaza hundida, y se encontraba encima de un par de atados, con dos dedos ungulados, posiblemente de camélidos o ciervos. Las aves en vuelo se repiten en una fila por debajo de la estructura escalonada, y dos crustáceos se encuentran a un lado de la figura principal. Una figura con forma de gusano con un rostro humano está en la misma zona. Tanto la estructura escalonada y las prendas de vestir de las figuras están cubiertas con motivos

12 La sugerencia fue atribuida a Jane Feltham (Jiménez 2006: 252). Aunque esto aún no puede ser demostrado con los textiles de contextos arqueológicos, la sugerencia puede tener mérito. 

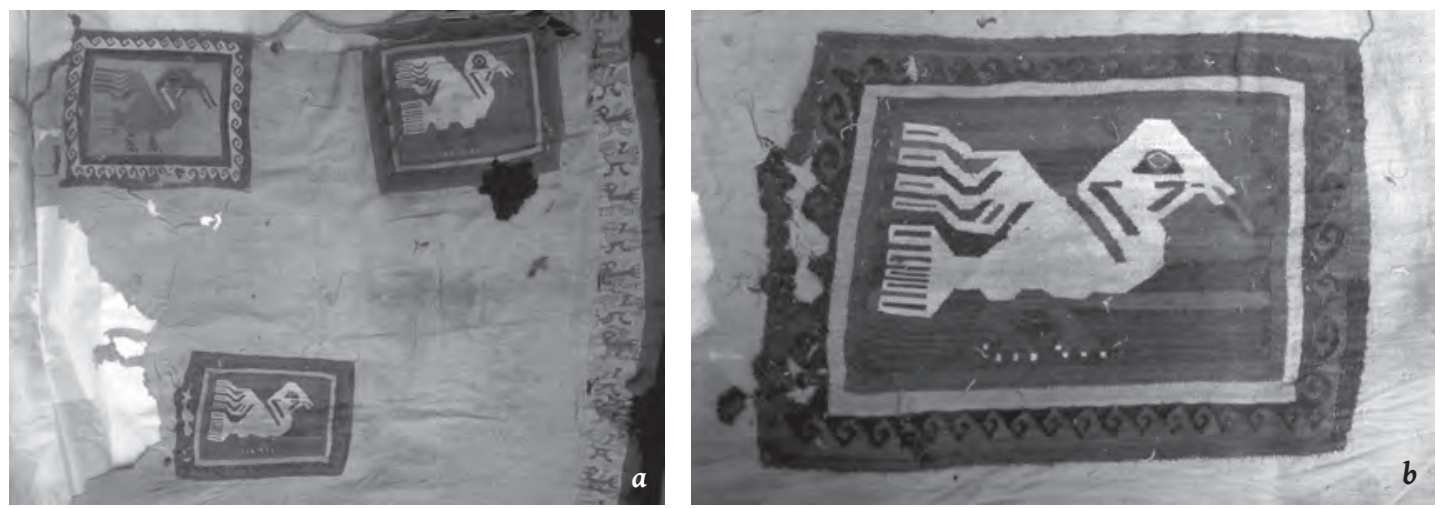

Figuras 18 a y b. La tercera capa del fardo incluye un manto amarillo de tres paños con parches en tapiz y un borde (a). El parche presenta aves marinas, posiblemente pelícanos, enmarcados por motivos que parecen ser olas (b). 371 (la dirección de las urdimbres de la tela de fondo es horizontal) x $93 \mathrm{~cm}$ y $375 \times 98 \mathrm{~cm}$. \#15, SM 363.02.2121. Parche en tapiz: $22 \times 28 \mathrm{~cm}$.

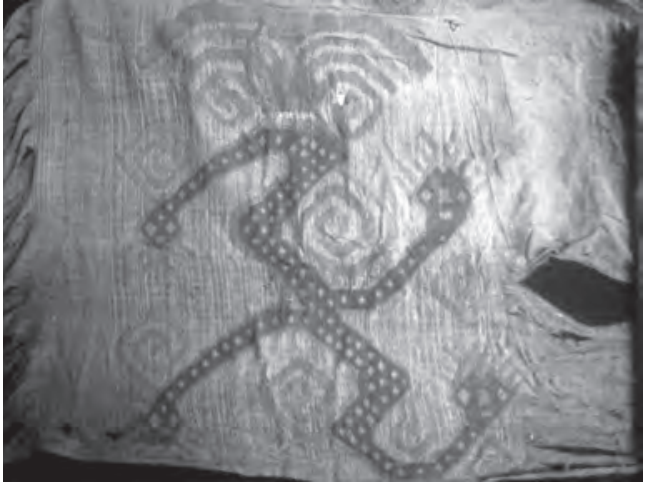

$a$

Figuras 19 a y b. Una figura única, que podría ser una planta con caracteres zoomorfos (b), está hecha con la técnica del brocado (a). El gran fragmento del manto de tres paños estaba en la cuarta capa del fardo. 250 (la dirección de las urdimbres es horizontal) x $180 \mathrm{~cm}$. \#18, SM 363.02.1998.

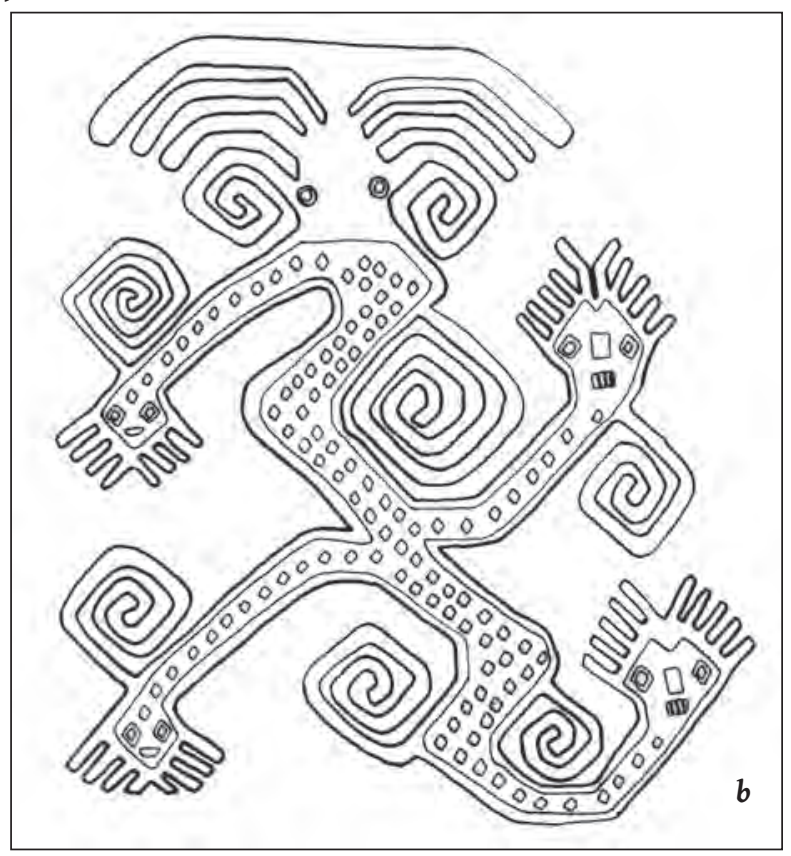

geométricos dispuestos en diagonal, que también se repiten en los cuerpos de algunos de los animales más pequeños.

Una característica inusual de la composición del diseño es la asimetría, que incluye no sólo la ubicación de figuras menores, sino también la fisiología de los motivos. La figura principal tiene un hombro que es más pequeño y más bajo que el otro, y muestra un número diferente de dedos en cada mano (Fig. 21C). La asimetría de las manos de la figura se repite en las garras de diferentes tamaños de los crustáceos, que tienen sus extremidades asimétricas levantadas en un gesto similar (Fig. 21b). Las diferencias en las manos y uñas sugieren que la asimetría fue intencional, y presenta la posibilidad de que la figura es una representación del hombre con la columna vertebral torcida del mismo fardo. Su enfermedad pudo haberlo marcado como especial en un sentido positivo, ya que parece ser que preside un sacrificio de ungulados atados con sogas al cuello en un marco arquitectónico. Este tipo 


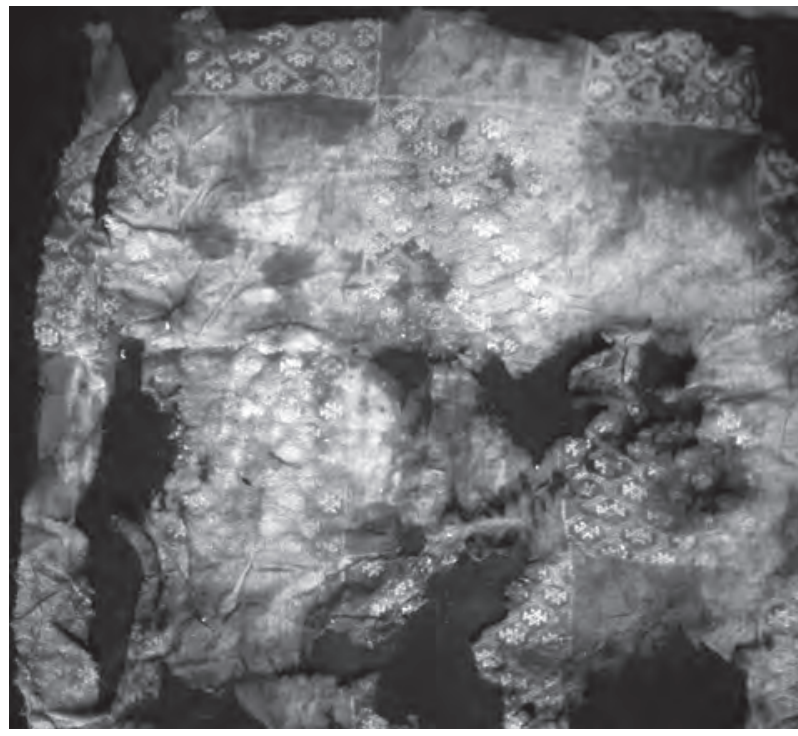

Figuras 20 a y b. Un fragmento de brocado encontrado a los pies del fardo tiene un patrón geométrico organizado en forma de damero (a) con rombos dentados repetidos dentro de los cuadrados alternos (b). La fibra y el hilo de la construcción son los típicos de los textiles Ychsma, aunque la figura geométrica no lo es. $85 \times 70 \mathrm{~cm}$. \#21, SM 363.02.2078.

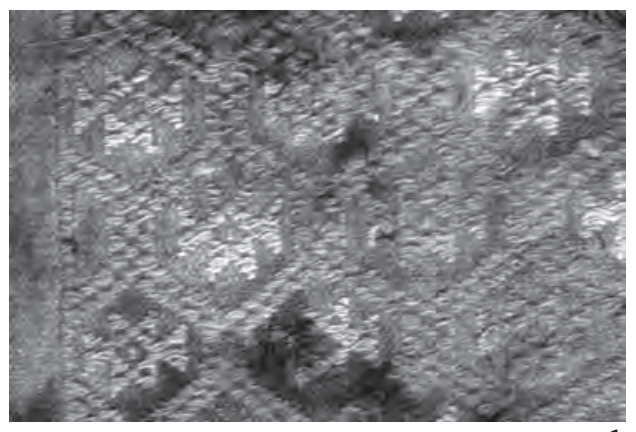

a

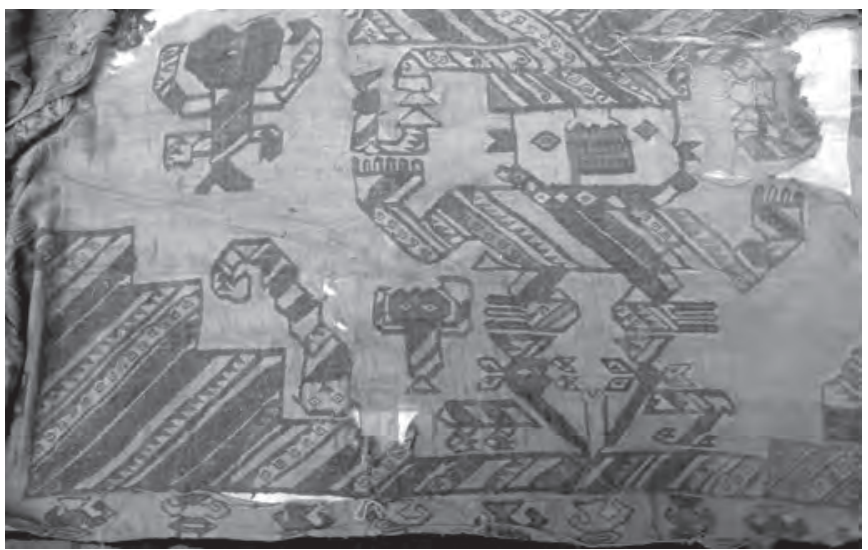

$a$
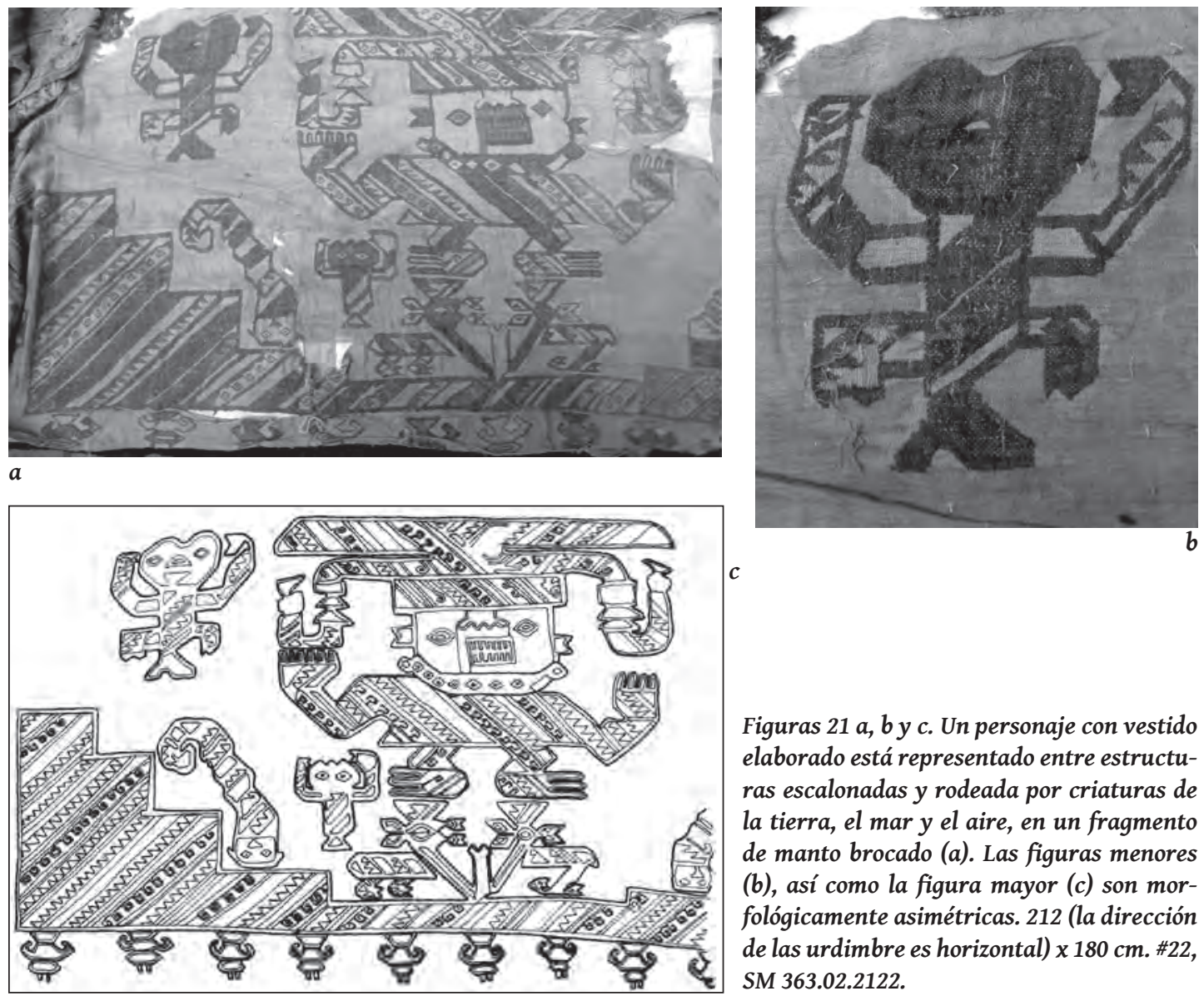
de sacrificio se representa en un elaborado tejido con características arquitectónicas de Pacatnamú (Donnan 1986: Figuras 1 y 2). La figura vestida en el brocado de Armatambo parece ser identificada con las criaturas asimétricas en el mundo natural.

El conjunto arquitectónico y la distribución asimétrica de las figuras de fondo son rasgos estilísticos notables de los textiles Ychsma que también aparecen en los textiles de los estilos norteños (Donnan 1986: Figuras 1 y 2; Conklin 1990: Figuras 12 y 13). Las características compartidas sugieren que las dinastías del norte ejercen una fuerte influencia en el estilo Ychsma durante el Horizonte Tardío, y tal vez antes también. Sin embargo las características técnicas, tales como la torsión de hilos, indican que el manto pertenece a la tradición regional de la Costa Central y del Sur, y no a la tradición norteña ${ }^{13}$. El tamaño, aunque fragmentado, la construcción de tres paneles, el uso exclusivo de los hilos de algodón y la técnica de brocado son típicos de los textiles Ychsma. La construcción del hilo y el tipo de brocado son los mismos en la mayoría de los mantos del fardo. La paleta de colores de ladrillo, verde, azul, rosa oscuro, además de los tonos naturales de algodón, son típicos de los textiles Ychsma. Las distintivas tonalidades suaves surgen porque el algodón no acepta tintes tan fácilmente como la fibra de camélido.

Son típicos de Ychsma los mantos de tres paneles con grandes diseños en brocado, pero estas figuras son excepcionalmente grandes, más de $100 \mathrm{~cm}$ por $60 \mathrm{~cm}$. Quedan restos de seis figuras, pero no ha sobrevivido ninguna figura completa con ambos lados de la estructura escalonada. Si la longitud original estaba cerca de los $400 \mathrm{~cm}$, es probable que se repitieran nueve figuras en los tres paneles del manto. Entre las demás figuras, el color de la cara es rojo, verde o blanco, lo que podría indicar que las figuras del mismo color se repiten en disposición diagonal, como en otros mantos.

El siguiente textil del fardo fue una camisa en tapiz de alta calidad, confeccionada con dos paños doblados a la altura del hombro y unidos por costuras al centro y los laterales (\#23, Fig. 22a). La camisa de algodón muestra figuras serpentinas en cada cuadrante y un borde inferior muestra aves nadadoras que tienen una gran cabeza crestada. El borde está flanqueado con franjas horizontales, y está tejido con las mismas urdimbres que el cuerpo de la camisa. Tejida por separado lleva una flecadura con tramas amarillas, formando anillos, que se cose al borde inferior. La gama de colores incluye tonos crema, beige, dorado, marrón, blanco y azul. El tamaño, la construcción y proporciones, así como la disposición del borde, son características típicas de las camisas en tapiz Ychsma. Las imágenes de las camisas en tapiz Ychsma son extensamente variadas e incluyen muchas figuras inusuales que van desde los seres que llevan ropas a antropomorfos, zoomorfos y figuras geométricas. La gran escala de la figura de cuatro partes en esta camisa es inusual.

Las camisas presentan características técnicas que pueden considerarse estándar para las camisas en tapiz Ychsma. Características tales como los orillos de urdimbre (oculto bajo la flecadura) son distintivos del estilo. El borde inicial de la urdimbre tiene anillos sueltos, lo que sugiere el cordón de partida fue eliminado después de tejer. Las urdimbres del borde final fueron cortadas y oblicuamente entrecruzadas para hacer un borde acabado firme $(0,3 \mathrm{~cm}$ de ancho) que no se desenrede. El acabado de entrecruzado oblicuo en borde final puede sugerir la influencia de las tierras altas, ya que fue utilizado en las túnicas tapiz Inca y Wari ${ }^{14}$. La banda de flecos, que generalmente es de color amarillo en las camisas Ychsma, tiene anillos de hilo abiertos en lugar de flecos retorcidos. El fleco de anillos es el resultado de utilizar un hilo de trama flojamente retorcido, por lo tanto no vuelve a retorcerse sobre sí mismo. El tapiz ranurado es la variante típica en el estilo Ychsma, y las ranuras de largo vertical entre las áreas de color están cerradas por costura (Fig. 22b). El tapiz no tiene igual acabado en

13 Ver Rowe (1984: 18-33) para una descripción de las características técnicas de los textiles Chimú, que pertenecen a la tradición norteña.

14 En las túnicas Inca y Wari, el borde oblicuo entrelazado se encuentra en las costuras laterales en lugar del borde inferior, ya que las urdimbres son orientadas horizontalmente, no verticalmente. 

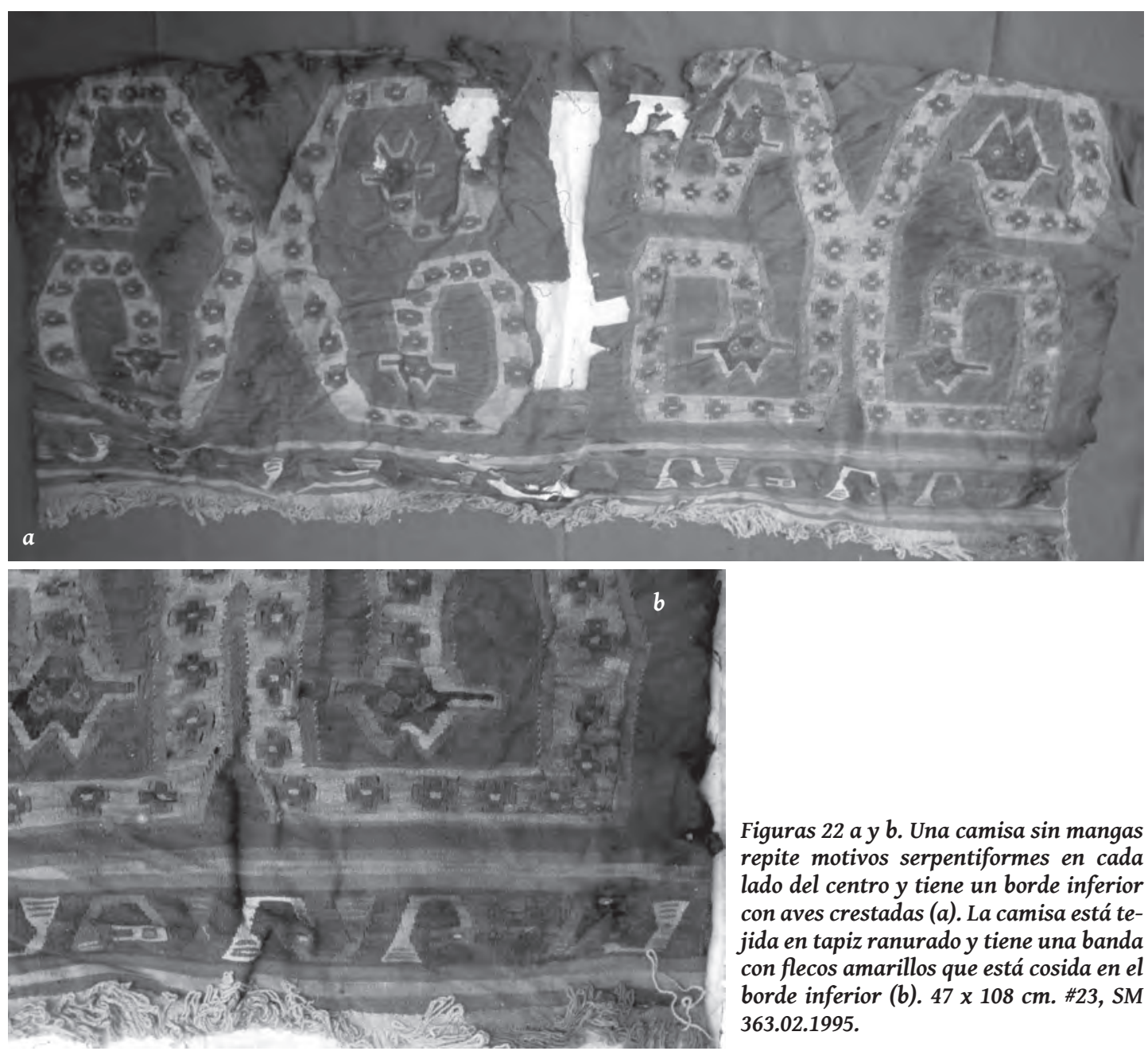

Figuras 22 a y b. Una camisa sin mangas repite motivos serpentiformes en cada lado del centro y tiene un borde inferior con aves crestadas (a). La camisa está tejida en tapiz ranurado y tiene una banda con flecos amarillos que está cosida en el borde inferior (b). $47 \times 108 \mathrm{~cm}$. \#23, SM 363.02.1995.

ambas caras, y algunas tramas son trasladadas a través de otra área de color en la cara inferior. Las urdimbres son Z-2S, y las tramas son de un cabo hilado en Z. Las urdimbres de la banda con flecos son S-2Z, lo cual es inusual, y las tramas son Z-2S. Las tramas de fibra de camélido amarillo son usadas para las bandas con flecos de la mayoría de las camisas, pero en este caso las tramas están elaboradas de algodón.

Los siguientes tres artículos del fardo son llanos o fragmentos. Se incluye una camisa de algodón blanco que está hábilmente tejido y acabado (\#24, SM 363.02.2143). Es similar en tamaño (48 x $100 \mathrm{~cm})$ y en la construcción de la camisa en tapiz, excepto que el fleco en el borde inferior es una extensión de los hilos de urdimbre del cuerpo de la camisa. Las urdimbres son Z-2S y las tramas son de un cabo hilado en Z. El segundo es un fragmento de banda con fleco amarillo del tipo de las empleadas en el borde inferior de las camisas en tapiz (\#25, SM 363.02.1987). Las urdimbres de algodón en esta banda con fleco son Z-2S-2Z, mientras que las tramas de algodón son Z-2S. La tercera pieza es un manto de algodón blanco compuesto por tres paneles con urdimbres y tramas Z-2S (\#26, SM 363.02.2124). Este manto de gran tamaño $(285$ x $180 \mathrm{~cm})$ tiene ribetes tubulares que se tejen y cosen (con el hilo de la misma trama) a los orillos de urdimbre. Las urdimbres de los bordes tubulares son de color marrón, 
dorado y blanco, y presenta un motivo geométrico compuesto de diamantes y triángulos que se repiten a lo largo del ribete. El panel presenta huellas de un pigmento rojo y depósito metálico verde, junto a una zona carbonizada. Una fotografía del fardo muestra que esta tela fue enrollada por el pecho, debajo de la barbilla.

El manto final en esta capa envuelve completamente el cuerpo vestido del individuo. El manto marrón tiene un diseño geométrico de círculos (\#27, Fig. 23), hecho en la técnica del teñido en reserva por amarres ("tie-dye"). Los círculos fueron producidos amarrando un hilo alrededor de pequeños secciones de tela, que impidieron la penetración de los tintes. El manto está carbonizado en muchas áreas, pero la longitud total de las urdimbres está presente $(280 \mathrm{~cm})$, así como fragmentos de dos paneles. El ancho total de un panel $(60 \mathrm{~cm})$ está presente, lo que sugiere que el manto original pudo haber medido $180 \mathrm{~cm}$ de ancho, si hubiese sido construido de tres paneles. Tanto los hilos de urdimbre y trama son de un cabo hilado en S, lo cual es inusual entre los textiles Ychsma, a excepción de los taparrabos. Cuando esta tela envoltoria fue retirada, la cara y el cuerpo vestido del individuo se hizo visible.

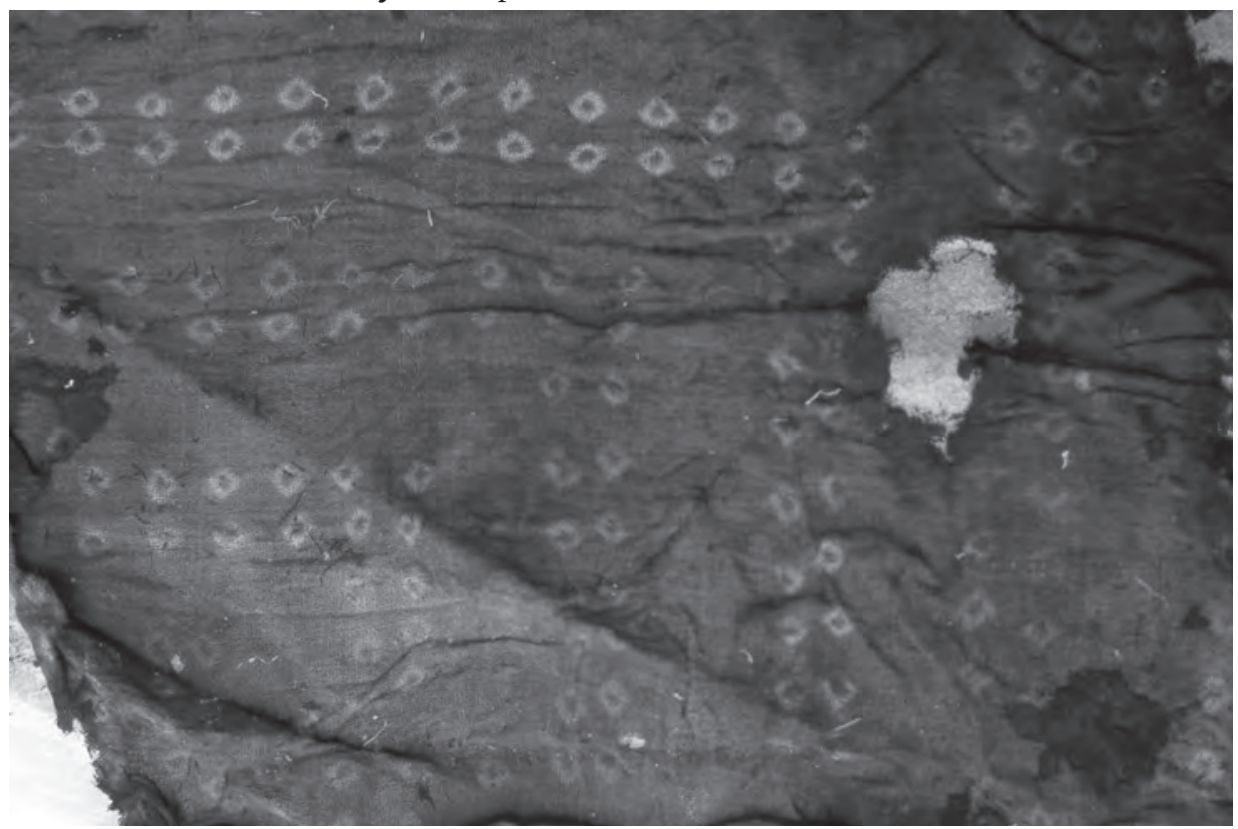

Figura 23. Los círculos en un manto marrón, que envolvió el cuerpo, fueron teñidos con reserva por amarres ("tie-dye"). Las filas pares forman un patrón que parece ser ganchos entrelazados. $280 \times 100 \mathrm{~cm}$. \#27, SM 363.02.2136.

Los textiles con los números 28,29 y 30 no fueron ubicados en el depósito textil. En un inventario (Ruales s.f. 2), el número 29 está asociado a dos placas de metal. Vallejo (1988: 400-401) menciona que los ojos del individuo estaban cubiertos de placas de una aleación de oro - plata y que plumas se insertan a los oídos con cuerdas. Es posible que a estos objetos les hayan asignado los números 28 al 30 durante el proceso de desenfardelamiento, y que están almacenados en otro depósito.

\section{Quinta Capa}

Las prendas que vistieron al difunto están en la capa final del fardo. Según Vallejo (comunicación personal), el individuo llevaba varios taparrabos. Los taparrabos tienen una forma distintiva que es más ancha en las extremidades que en el centro. Se produjo al cambiar la tensión y la densidad de las tramas, a medida que el tejido era avanzado. Cosiendo dos paneles al centro se genera una forma más 
pronunciada. El taparrabo más externo (\#31, Figs. 24 a y b) tiene un patrón de chevron en el borde del extremo más ancho. El patrón está tejido con tramas suplementarias embutidas en el mismo espacio que la trama del tejido base ${ }^{15}$. Una característica inusual en este taparrabo es el uso de tres tramas de color azul en cada extremo. Los taparrabos Ychsma tienen una textura similar al crepé, producida por el uso de hilos muy torcidos, que también incrementa la calidad de la elasticidad de la tela de algodón. Típicos taparrabos Ychsma, como éste, son elaborados con urdimbres y tramas de un cabo hilado en S. La dirección de la torsión indica que los hilos fueron torcidos manteniendo el huso en posición horizontal, un método típico de los estilos norteños. Es interesante señalar que los tejedores de Chancay también utilizaron hilos de una alta torsión, de un cabo hilado en S en las urdimbres y tramas, para un tipo de prenda única, que en el caso de Chancay fueron las telas de gasa para la cabeza empleadas por las mujeres. Tanto los hilanderos Chancay e Ychsma, a diferencia de los hilanderos de la costa norte, usaron un huso con ambos extremos puntiagudos que podría ser usado para hacer hilos con torsión $\mathrm{S}$ o Z al cambiar la orientación del huso.

La camisa exterior que fue llevaba por el individuo es de color marrón oscuro, y se ajusta a las proporciones y construcción de camisas costeñas en general (\#32, Fig. 25). Se compone de dos paneles de tela con aberturas para la cabeza y los brazos producidas al dejar vacíos en las costuras. El borde inferior con patrón de aves dispuestas en diagonal, se tejió con las mismas urdimbres del cuerpo de la camisa. Tanto la estructura utilizada en el borde (ligamento de tramas complementarias) y las bandas amarillas y rojas que flanquean el borde, son características que se encontraron en las camisas costeñas de otras zonas de la costa durante el Horizonte Tardío. El cuerpo de la camisa de algodón tiene hilos en Z-2S, y las tramas listadas y los bordes están elaborados de hilos de fibra de camélido (también en Z-2S). Una característica que parece ser específicamente Ychsma es la banda amarilla con flecos que se cose al borde inferior. Los anillos del fleco están abiertos y sin cortar, de forma similar a los ejemplos anteriormente descritos, y en este caso el hilo de trama amarilla es de fibra de camélido. Las figuras del borde se trabajan en dos tonos de dorado, excepto en un área en donde el púrpura es sustituido por uno de los colores. Este tipo de camisa parece ser el modelo costeño de un tipo de túnica Inca provincial, que tiene proporciones largas y estrechas, pero un tratamiento en el borde similar (Frame et al. 2004: Figuras 8 y 9; Uhle 1991: Figura 50).

Una ofrenda, consistente en una valva de spondylus, fue rellenada con fibra de algodón y envuelta con un gran fragmento de taparrabo de algodón (\#33, Fig. 26). Vallejo (1988: 401) sugiere que la valva envuelta originalmente pudo haber sido colocada en las manos del individuo. La colocación de la ofrenda es interesante a la luz de la imagen en un textil brocado del relleno (\#50, Fig. 7b). La figura masculina podría sostener valvas de spondylus con características antropomorfas en sus manos. El fragmento de taparrabo que envuelve la valva es similar en la construcción y torsión de los hilos (todos de un cabo hilado en S) como el otro taparrabo que acabamos de describir (\#31, Fig. 24). El dibujo en la parte inferior consiste en listas horizontales de color beige y marrón. La unión entre la zona llana y con diseño, que sigue diagonales opuestas que se elevan desde la costura central hacia los bordes exteriores, se logró mediante el uso de tramas discontinuas.

El taparrabo interior que estuvo directamente en el cuerpo del difunto (\#34, Fig. 27) carece de dibujos, pero es similar en la construcción y torsión del hilo a los especimenes \#31 y \#33. La consistencia de los tres ejemplos confirma las características tecnológicas de este tipo de taparrabo Ychsma. Otros similares han sido descritos en Rinconada Alta (Frame et al. 2004: 835-36 y en la Figura 17) y de Pachacamac (Feltham 2002: Figura 7). La forma de taparrabo Ychsma (ancho en los extremos), de acuerdo con un estudio más amplio, tiene una distribución que se extiende desde Ate en el valle del Rímac, hasta el valle de Chincha (Osborne 1950). No hay informes sobre ejemplos de estilo Chancay, donde los taparrabos

15 Esta técnica de tramas suplementarias ("inlay") difiere del brocado, donde las tramas suplementarias se añaden en las hileras que son distintas de las hileras de las tramas de la tela base. 

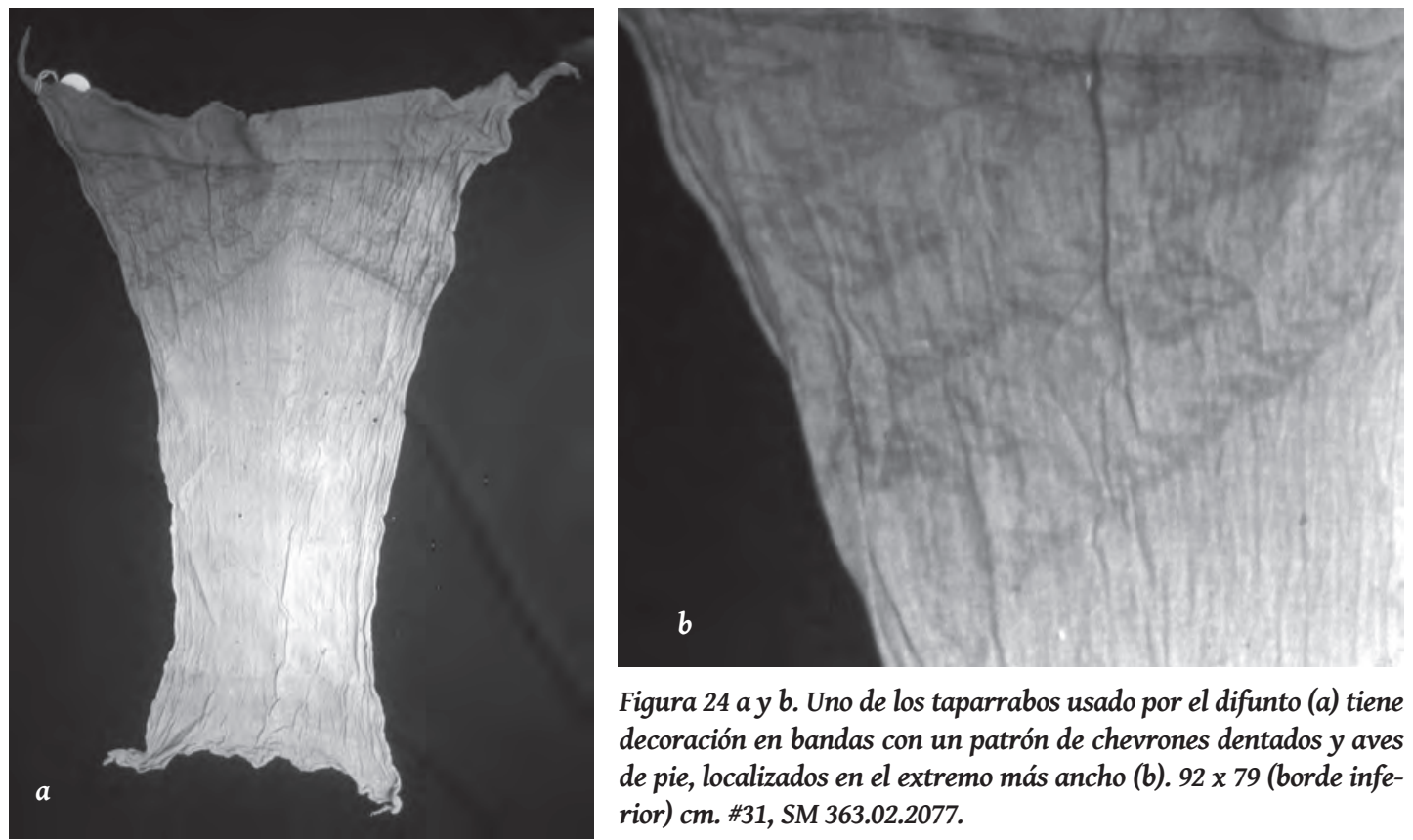

Figura 24 a y b. Uno de los taparrabos usado por el difunto (a) tiene decoración en bandas con un patrón de chevrones dentados y aves de pie, localizados en el extremo más ancho (b). $92 \times 79$ (borde inferior) cm. \#31, SM 363.02.2077.

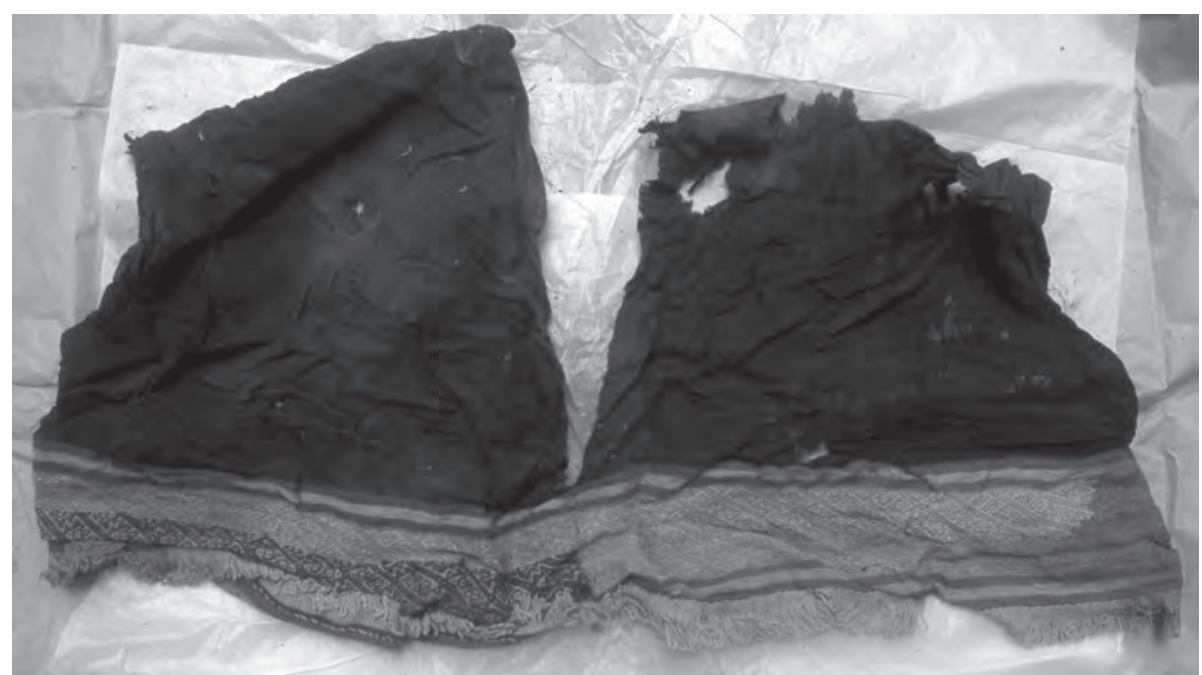

Figura 25. El difunto vestía una camisa color marrón con borde rojo y dorado encima de varias otras camisas. $65 \times 140 \mathrm{~cm}$. \#32, SM 363.02.2098.

rectangulares con una faja agregada parecen ser la norma. El taparrabo llano usado por el individuo (Fig. 27) ofrece nueva información sobre cómo se llevaba el taparrabo. Las dos esquinas del extremo más ancho todavía están anudadas. Está claro que ningún lazo adicional fue utilizado para sujetar el taparrabo alrededor de la cintura. Es probable que el extremo libre, que es un poco menos ancho, pasara entre las piernas, debajo de las esquinas anudándose en el talle, y colgándose hacia abajo como un delantal. Si este fuera el caso, las áreas triangulares con diseños en el extremo más ancho del taparrabo, como los especimenes \#31 y \#33 (Figs. 24 y 26), habrían cubierto las nalgas.

El individuo llevaba cuatro camisas, una de las cuales se ha descrito (\#32, Fig. 25). Dos de las camisas, \#36 (SM 363.02.2142) y \#38 (SM 363.02.2106), están elaboradas en ligamento llano de algodón 


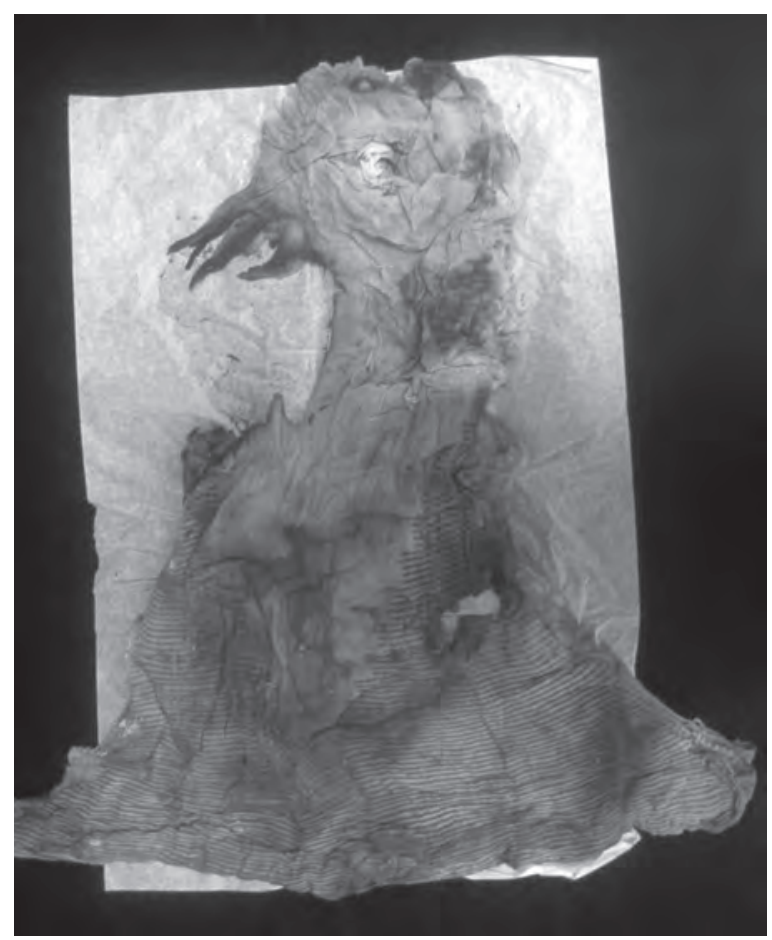

Figura 26. Una valva de spondylus rellena con fibra de algodón, fue hallada envuelta en este fragmento de taparrabo. 75 $x 84 \mathrm{~cm}$. \#33, SM 363.02.2105.

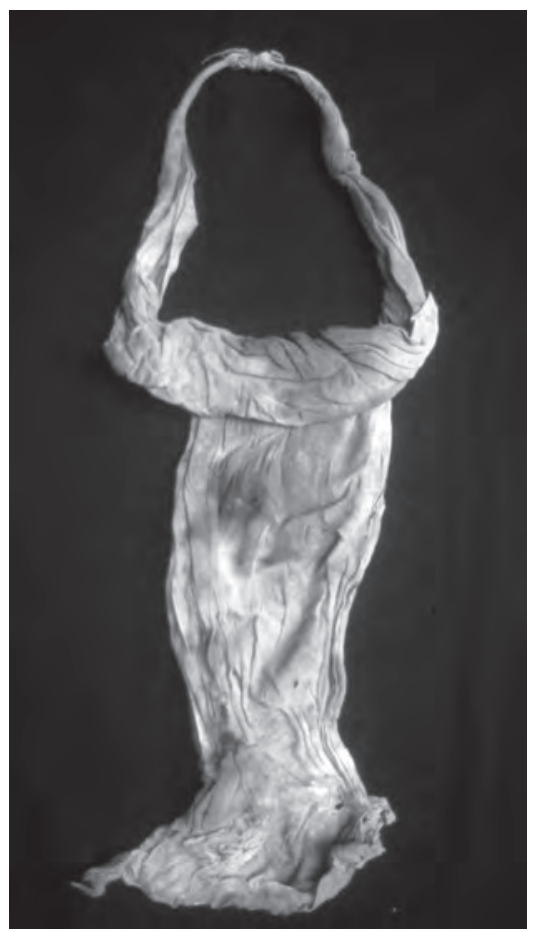

Figura 27. El taparrabo interior que todavía usaba el difunto tiene nudos en las esquinas de la parte más ancha, indicando como fue atado a la cintura. \#34, SM 363.02.2088.

blanco. Ambos se construyeron con dos paneles de tela que se doblan en los hombros y se cocieron al centro y en los laterales, dejando aberturas para los brazos y la cabeza. El primero, \#36, es similar a otra camisa del fardo (\#24), que tiene flecos de urdimbres en el borde inferior, urdimbres en Z-2S y tramas de un cabo hilado en Z. Sus dimensiones, 41 x $96 \mathrm{~cm}$, son ligeramente más pequeñas que el \#24 y la estructura es un poco más suelta. La segunda camisa llana (\#38), se encontraba junto al cuerpo, está rota a lo largo del borde inferior y tiene muchas adherencias y alguna pérdida estructural en una esquina superior. Las urdimbres son de un cabo hilado en $\mathrm{S}$ mientras que las tramas son de un cabo hilado en Z. Las dimensiones de la camisa, que están incompletas en el sentido de las urdimbres, son de $45 \times 99 \mathrm{~cm}$.

Entre las camisas llanas, el individuo llevaba una camisa en tapiz elaborado de algodón (\#37, Fig. 28a). La construcción con dos paneles, y las proporciones cortas y anchas son características de las camisas de la región costeña central y sur, y son las mismas en todas las camisas del fardo. La fibra, la torsión del hilo, el color de la banda con flecos y el formato del borde inferior de esta camisa en tapiz son muy similares a otra camisa tapiz del fardo (\#23, Fig. 22). El tratamiento de los orillos de urdimbre es el mismo, con anillos de urdimbre en uno de los extremos y urdimbres cortadas y oblicuamente entrecruzadas al otro.

La camisa también tiene características adicionales que amplían el rango de variación dentro del tipo. A pesar de que se teje en el tapiz ranurado, también es un tejido de calado semi-transparente. El calado se logra dejando desnudas las urdimbres en algunas zonas (Fig. 28b), en lugar de cubrir completamente las urdimbres con las tramas. El patrón de repetición de las serpientes entrelazadas en el cuerpo de la camisa es muy diferente de las figuras monolíticas de otra camisa tapiz del fardo (Fig. 22a). Sin embargo, ambos enfoques de diseño están presentes en una muestra más amplia de camisas 

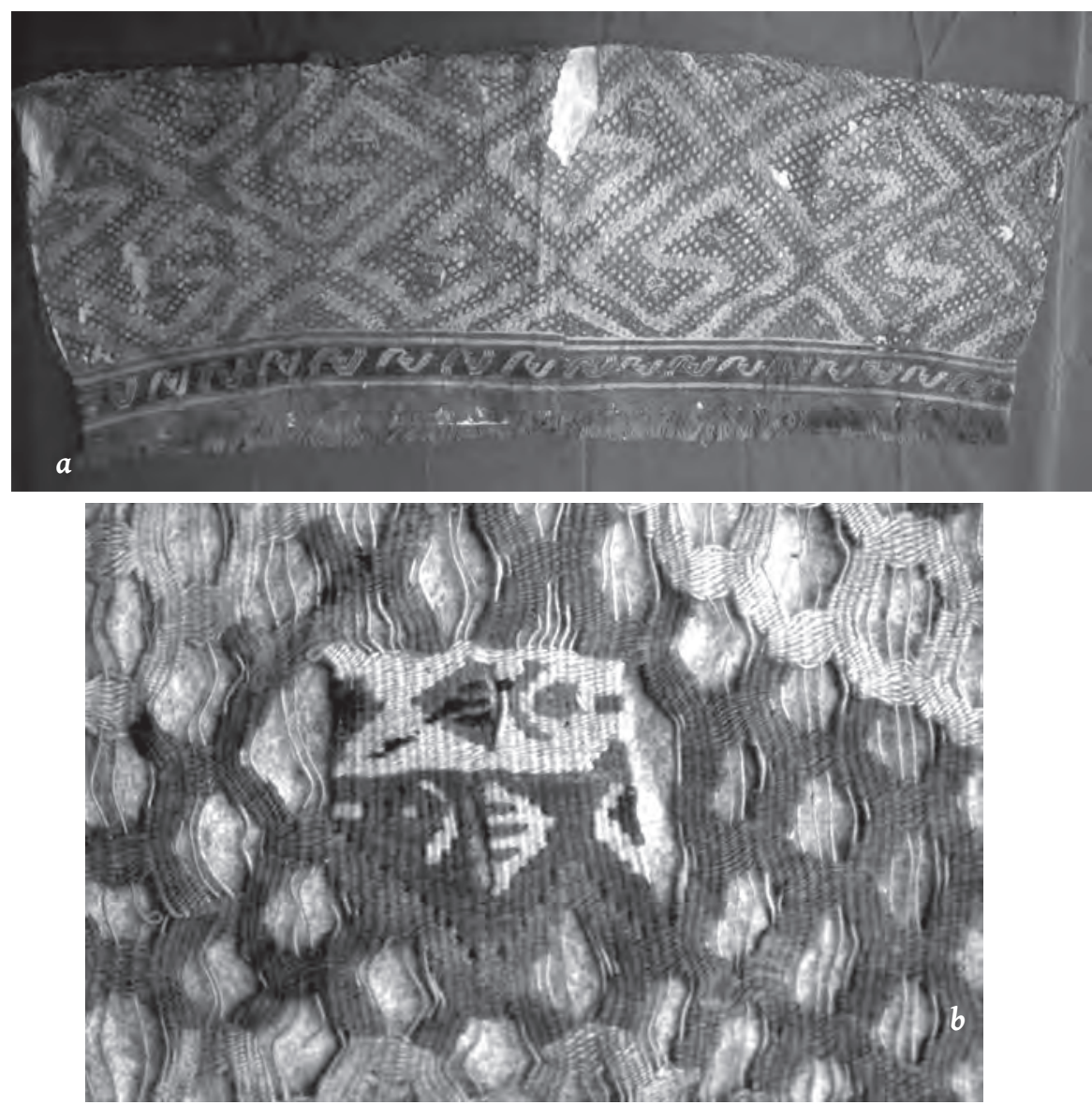

Figura 28 a y b. Una camisa en tapiz calado, que muestra un diseño de serpientes entrelazadas, fue usada por el difunto (a). La figura de un pequeño pez forma el ojo de cada serpiente (b). 46 × $127 \mathrm{~cm}$. \#37, SM 363.02.1997.

de tapiz en colecciones de museos, que pueden ser identificados como Ychsma, en base a las características técnicas y estilísticas de las camisas del fardo. De hecho, la variedad de figuras y patrones es una característica sobresaliente de las camisas y fragmentos de tapiz Ychsma, no hay dos iguales en la muestra reunida.

Los últimos objetos del fardo incluyen un paño de algodón, dos almohadillas de algodón, hilos y tres plumas. La tela de algodón (\#39, SM 363.02.2145), que tiene bandas estrechas de color marrón en los orillos de trama y dimensiones de 46 x $48 \mathrm{~cm}$, se deforma en diagonal como si hubiera sido envuelto o atado a algo. La tela conserva la impronta de algo así como granos de maíz en la textura. Las urdimbres son de un cabo hilado en S, a excepción de las listas laterales, que son de un cabo hilado en Z, al igual que las tramas. Fibra de algodón e hilos (\#39a, SM 363.02.2089) están listados en el inventario como procedentes del compartimento D (Ruales s.f. 1), pero no fueron ubicados en el depósito. No fue ubicado ningún textil que corresponde al espécimen \#40 de este contexto. Tres plumas de color rosado y crema, que miden 13 x $4 \mathrm{~cm}$, corresponden al espécimen \#41 (SM 363.02.2139). Dos almohadillas de fibra de algodón despepitada (\#42, SM 363.02.2146) están asociadas a un objeto metálico (también \#42), de acuerdo con el inventario. El elemento metálico, según lo descrito por Vallejo (1988: 400 y 421), fue una placa cuadrada de metal con agujeros en las esquinas que cubría el pene. Este es el elemento final que se registró en el desenfardelamiento del individuo. 


\section{EL TRATAMIENTO FUNERARIO DEL INDIVIDUO}

El tratamiento mortuorio del cuerpo, así como la variedad y cantidad de textiles en el fardo, sugieren que la persona pudo haber tenido un estatus particular y/o un alto rango. El uso del metal indica su alto rango. Las placas metálicas en los ojos no son inusuales en los entierros de los Andes. La funda del pene, que está fabricada con una aleación de oro y plata, es un elemento poco frecuente, y simbólicamente podría indicar el carácter de un progenitor (Vallejo 1988: 400). El pene está representado en las figuras masculinas en uno de los mantos brocados del relleno de la tumba (Fig. 7). La asimetría del cuerpo de las figuras en el manto sugiere que la figura podría ser un retrato del enterrado. La malformación de la columna vertebral y la postura resultante puede haberle conferido un estatus especial, tal como se representa a un hombre con cuerpo asimétrico en el segundo manto (Fig. 21). El énfasis en los genitales masculinos, la presencia de una mujer joven sacrificada, así como tres figurillas femeninas que fueron colocados en la tumba, parecen poner énfasis en la fertilidad y la procreación humana, que está insinuada en la funda del pene.

Vallejo (1988: 400) relata que los brazos y las piernas del fallecido fueron pintados de color azul oscuro con dibujos geométricos, principalmente rombos, y que su rostro fue pintado con un polvo rojo disuelto en un líquido. Las plumas sujetas a sus oídos con cordones también eran de color rojo. Uno de los lados de las placas de metal que cubrieron los ojos fue pintado de color rojo (Vallejo 1988: 419) y una ofrenda de una valva de spondylus, color rosa, fue colocada cerca a una mano. El énfasis por el rojo no es inusual en los contextos funerarios, pero resalta aquí porque el nombre Ychsma se considera derivada de una palabra que designa el color rojo del azogue o del achiote (Rostworowski 1977: 72-3).

El fardo funerario parece haber sido preparado de acuerdo a rituales establecidos. El individuo estaba vestido con cuatro camisas y dos taparrabos, su frente estaba pintada de color rojo, placas de metal fueron colocadas en sus ojos y pene, las plumas fueron sujetadas en sus orejas, su cara estaba cubierta por fibra de algodón y una ofrenda de valva de spondylus se puso en su mano, antes de ser cubierto con el manto que fue teñido en reserva por amarres. Capas de textiles, separados por los amarres, se han añadido al bulto. Un número de fragmentos tienen signos haber sido reutilizados, tal vez rescatados de otras tumbas. Otros tienen indicios de haber tenido un uso específico, pero desconocido. La tumba tenía muchas ofrendas, incluyendo el cuerpo de una joven mujer y un recién nacido. Diez parches tapiz en forma de peces fueron colocados en la tumba, quizás indicando un paralelismo conceptual entre la tumba y el mar. Tanto el fardo como la tumba contribuyen a reconstruir una vívida imagen de los rituales mortuorios de este periodo, así como una imagen detallada del estilo textil Ychsma.

\section{El estilo Ychsma durante el Horizonte Tardío}

El contexto de Armatambo proporciona datos que son la base para el establecimiento de una definición del estilo Ychsma durante el Horizonte Tardío. Si bien todos los estilos de tradición central y sureña de la costa empleaban hilos de algodón para las urdimbres, los Ychsma a diferencia de otros estilos prefieren hilos de algodón para las tramas de tapices y tramas suplementarias en brocados. Las tonalidades de algodón teñido son menos intensas que las obtenidas en fibras de camélidos, por ello la mayoría de tapices y brocados Ychsma tienen un aspecto muy diferente a los textiles Chancay o Ica. La preferencia Ychma en la torsión de los hilos también difiere en algunos aspectos de otros estilos, aunque son difíciles de caracterizar de manera concisa porque la variabilidad es una característica dominante. La diferencia más destacable es su preferencia por la torsión de un cabo hilado en Z, a menudo de dos o tres cabos, en las tramas de los tapices ranurados y las tramas suplementarias de los brocados. También es notable el uso de un cabo hilado en $\mathrm{S}$ en las tramas y urdimbres de taparrabos y de mantos bordados o teñidos en reserva. Las urdimbres de la mayoría de los textiles Ychsma son $\mathrm{Z}-2 \mathrm{~S}$, al igual que otros estilos de la tradición central y sureña de Costa, pero las tramas base de los textiles brocados Ychsma y telas de ligamento llano pueden variar en el extremo, incluso dentro del mismo textil. Junto a la mayoría de los tapices Ychsma con tramas de algodón existe un número pe- 
queño, pero significativo, con tramas de fibra de camélido que sigue el esquema de color Inca de rojo, dorado, blanco y negro. La variedad de textiles podría reflejar las oleadas de influencia tecnológica y estilística de las dinastías norteñas y del altiplano en los tejidos de los Ychsma, que eran los guardianes del santuario más venerado y visitado en la costa.

\section{COLECCIONES COMPARATIVAS}

Utilizando la combinación de datos gráficos y técnicos del contexto de Armatambo, es posible identificar muchos textiles Ychsma en colecciones de museos y cotejar una muestra mucho mayor. Algunos de los museos con colecciones textiles, en particular la colección Uhle del Museo de Arqueología y Antropología de la Universidad de Pennsylvania, la colección Bandelier de Surco (Valle del Rímac) y la colección Gaffron de Márquez y Chuquitanta (Valle de Chillón) en el Museo Americano de Historia Natural y la colección Gretzer en el Museo Etnológico Staatliche Museen zu Berlin, así como algunos textiles en el Museo de Arqueología y Etnología Peabody de la Universidad de Harvard, conservan datos de procedencia o excavación que se pueden considerar fidedignos. Los textiles de Armatambo y Rinconada Alta, excavados por Daniel Guerrero y Luisa Díaz, y la publicación de textiles excavados por Peter Eeckhout en Pachacamac, también forman parte de la muestra así como los textiles de los museos de sitio de Pachacamac y Puruchuco. Muchos textiles Ychsma de los museos que se enumeran en las notas, se pueden encontrar en las fuentes citadas o verse en los sitios web de los museos. La información disponible sobre la procedencia, que se resume en el texto, sugiere los límites de la esfera de influencia Ychsma durante el Horizonte Tardío (Fig. 29). Los textiles sin procedencia contribuyen a ampliar los compendios de imágenes, los patrones y las variantes técnicas en los tejidos Ychsma.

\section{Parches de Tapiz}

Los textiles más característicos son los parches en tapiz en forma de peces (Figs. 5 y $16 a$ y b), que parecen ser propios del estilo Ychsma ${ }^{16}$. Son tejidos en su forma final y presentan diversos contornos y varios dibujos. Casi invariablemente, los parches son de algodón en colores típicos Ychsma: blanco, azul y varios tonos de café. La torsión de los hilos es bastante consistente (Z-2S para las urdimbres y generalmente un cabo hilado en $\mathrm{Z}$ para las tramas). Las uniones entre las áreas de color son variables e incluyen ranuras, ranuras cosidas, ocasionalmente tramas ensambladas o trabadas ("dove-tailed or interlocked joins"), y tramas flotantes ("underfloating wefts"). Un parche en forma de pájaro fue localizado en Pachacamac (Schmidt 1929: 502, derecha), pero los otros son peces. Los datos de procedencia de los especimenes reunidos se limitan a Armatambo (este contexto) y Pachacamac.

Los parches cuadrados en tapiz (Figs. 9, 18a y b) son también distintivos ${ }^{17}$, y el contexto de Armatambo pone de manifiesto que tanto los parches cuadrados como los parches en forma de peces

16 Para los parches de peces de algodón tejidos en tapiz, consulte Benson 1997: Lámina 7 (Pachacamac, UPM 30370, colección Uhle); Bird 1962: Figura 35, arriba (TM 91.193); Engelstad 1980: figuras 3, 6 y 11; de Lavalle y González, 1988: 269; de Lavalle y Lang, 1977: 150; Stone-Miller, 1992: Lámina 58 (MFAB 31.710); Ubbelohde Doering 1952: Figura 76 (Pachacamac, EMB, colección Gaffron); AIC 1955.1698; CMA 1933.392, y MNAA RT 1645.

17 Para los parches cuadrados de algodón tejidos en tapiz, ver Benson 1997: Lámina 8 (Pachacamac, UPM 32609, colección Uhle); Bjerregaard 2002: 74 (Pachacamac, NMD 0.4277b, ex-colección Gretzer de EMB) y 105 (NMD 0.4407b, ex-colección Gretzer de EMB), Eeckhout 1999: Figura 25 (Pachacamac), Jiménez Borja 1999: Láminas 5, 6, 9 y 10 (dice que son de Pachacamac), de Lavalle y González, 1988: 252-3; Reina y Kensinger 1991: Figura 1.18 (UPM CG852611-6459), Schmidt 1910: Figuras 19 y 37 (Pachacamac), Schmidt 1929: 500 - 502 (Pachacamac, EMB, colección Gretzer); Taullard 1949: Figura 68 (dice que es de Ica); Ubbelohde Doering 1952: 80 (Pachacamac, EMB, colección Gaffron); AIC 1955.1699, AIC 1955.1700; AIC 1955.1762; AMNH B/1345A (Surco, colección Bandelier); AMNH 41.2/746, AMNH 41.2/747; AMNH 41.2/5407; BM Am1954,05.480; MdqB 71.1947.0.5.776; MMA 28.64.3, 8, 12, 23, 24 y 29; NMNH 133353 (Ancón); NMNH 133044a-e (Ancón); TM 91.104; y UPM 30369c (Pachacamac, colección Uhle). 


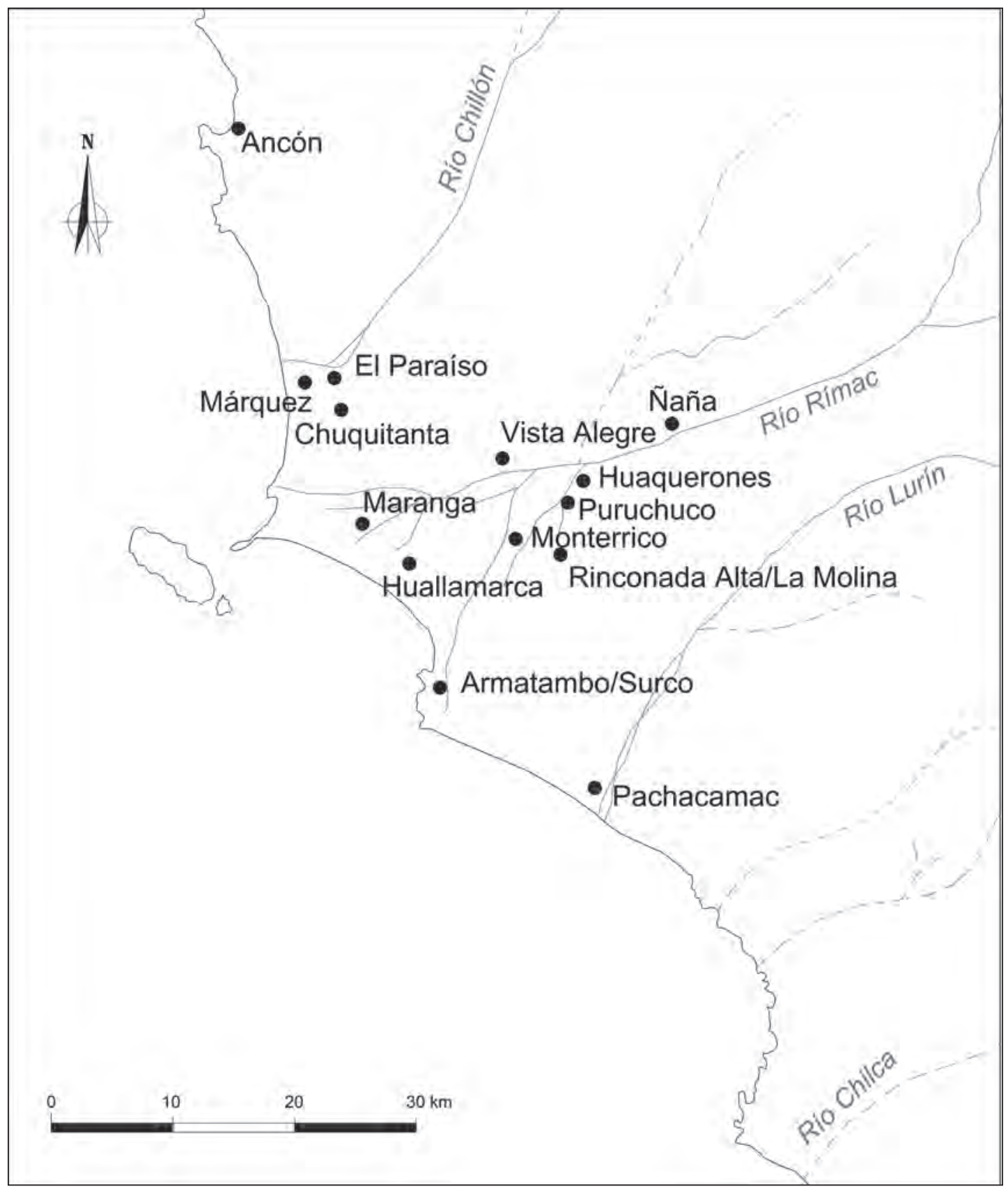

Figura 29. Mapa de la costa central con los sitios arqueológicos donde se encuentran los textiles Ychsma mencionados en este estudio. 
fueron cosidos a los mantos, formados por tres paños y bordes finales en tapiz. Parches sueltos que parecen ser fragmentos del manto doblado que estaba en el exterior del fardo, fueron encontrados en la parte interior del fardo (\#18e). El uso del tapiz ranurado, la preferencia por los hilos de algodón y la gama de colores suaves (con algunas excepciones) ${ }^{18}$ son características típicas de estos textiles. Las urdimbres usualmente son Z-2S y ocasionalmente en Z-3S, mientras que las tramas son a menudo de un cabo hilado en $Z$, pero hay una variedad de hilos de trama, incluyendo casos de un cabo hilado en $S$, Z-2S, e incluso S-2Z. El tapiz no fue terminado de manera similar en ambas caras, pero los cuatro bordes están muy bien acabados, incluyendo el orillo final. La iconografía se divide en varias categorías: animales (especialmente peces, aves y felinos); los seres humanos o antropomorfos, a menudo con muchas pequeñas figuras en el espacio de fondo; plantas; y escenas con figuras múltiples, incluyendo escenas de flotantes con nadadores, spondylus y peces. Muchos de los parches cuadrados muestran figuras zoomorfas y motivos geométricos, que se repiten en los cuatro lados. La información disponible indica que la procedencia de los parches en tapiz es de Armatambo, Pachacamac, Surco y Ancón. Un único ejemplo se dice proviene de Ica, pero la información sobre su procedencia no parece fiable.

Grandes mantos con figuras pintadas que imitan parches de tapiz también parecen ser de estilo Ychsma, aunque no hay ejemplos de imitaciones pintadas incluidas en el contexto de Armatambo. Los textiles pintados ${ }^{19}$ muestran la misma disposición de peces o cuadrados con bordes, como los mantos con parches en tapiz, y algunos duplican los bordes finales de los tejidos originales (Figs. 16a y 18a). Textiles con imitaciones pintadas de parches en tapiz, se dice que provienen del valle de Rímac, de los sitios de Armatambo, Surco, La Molina y Rinconada Alta, así como de Ancón.

\section{Camisas en Tapiz}

Los parches en tapiz, a través de su iconografía, esquemas de color, fibras y técnicas características (las estructuras de los hilos y las uniones en los tapices) tienen una fuerte conexión con las camisas en tapiz de este estilo, incluyendo los que están en el fardo de Armatambo (Figs. 22a y 28a). Un número significativo de camisas en tapiz similares se encuentran en colecciones de museos ${ }^{20}$, y dan una idea de cuán amplio es el repertorio figurativo en este estilo. Mientras que predominan los peces y las aves, también están presentes los monos, felinos, plantas, seres humanos vestidos, diseños entrelazados y motivos geométricos con pequeñas figuras de animales inscritos. En una ponencia reciente, Jane Feltham (s.f.) sugirió que las ranas comprendieron una categoría notable entre los animales

18 Parches cuadrados en tapiz también pueden incluir tramas teñidas de fibras de camélido, especialmente en rojo, negro y dorado. Existen ejemplos de estas versiones de colores brillantes en Pachacamac, ver Lavalle (1988: 156-7, PachSM). Agradezco a María Luisa Patrón por mostrarme un manto, de la colección de Pachacamac, con restos de un parche muy similar a los ejemplos publicados que están en exhibición. Ver también AMNH B/1223A (Surco) y MMA 28.64.3.

19 Para textiles pintados que imitan textiles con parches en tapiz, ver d'Harcourt 1962: Lámina 50A (Ancón, MdqB 84-91-65); Hyslop y Mujica 1992: Figura 14 (Surco, AMNH B/4522, colección Bandelier); de Lavalle y Lang, 1979: 147-151 (PurSM 001268); Schmidt 1929: 508, zona superior derecha (Pachacamac, EMB, colección Gretzer); Luisa Díaz (2003, Armatambo, encontrado en superficie); Daniel Guerrero (Rinconada Alta, cubierta exterior de la momia de 891, F-71); MdqB 71.1911.21.449; y PurSM RT 0831 (La Molina).

20 Para camisas de algodón en tapiz, véase Benson 1997: Lámina 9 (Pachacamac, UPM 32614, colección Uhle); Feltham 2002: Figura 13 (Pachacamac); d'Harcourt y d'Harcourt 1924: 21 (Pachacamac, MdqB 71.1964.86.147, (colección d'Harcourt); Jiménez Borja 1999: Láminas 1, 2, 8, 11 (cuatro camisas, dice que son de un contexto de Pachacamac); de Lavalle 1988: 258-9 (LACMA M.72.68.9); de Lavalle y Lang, 1982: 102-3; Morris y von Hagen, 1993: Figura 180 (AMNH B/7781, colección Gaffron); Stone-Miller, 1992: \#212 (BMFA 36.58); AMNH B/7778; AMNH B/8588 (Chuquitanta, colección Gaffron); BM Am 1954,05.550, BM Am 1965,03.6; MdqB 71.1933.0.271.98 y 71.1933.0.271.316 (2 mitades); MNAA RT 6392; MNAA RT 22883; MNAA RT 23710; MNAA RT 24204; NMNH 133385-D (Ancón); NMNH 133385-A (Ancón); PMH 46-77-30/10401 (Vista Alegre); PMH 46-77-30/10371A; TM 91.493, TM 91.501, TM 91.523 y TM 1966.7.30. 
representados en los parches rectangulares. A veces, múltiples figuras interactúan en escenas de depredación y lucha o actividades como la recolección de fruta de los árboles. Las camisas tienen bordes inferiores con figuras, a menudo azul y flanqueado por franjas estrechas. La mayoría se elaboran en tonos naturales de algodón, además de unos pocos teñidos, sobre todo azul. Una flecadura amarilla, por lo general tejida con tramas de fibra de camélido, casi siempre va cosida al borde inferior. Todas las camisas examinadas tienen el mismo tratamiento en el orillo terminal: urdimbres cortadas que son entrecruzadas oblicuamente. Una minoría de camisas está tejida con tramas de fibra de camélido, predominantemente en tonos de rojo, dorado, blanco y negro ${ }^{21}$. La información sobre la procedencia de los tejidos examinados, en colecciones de museos o identificados en las publicaciones y colecciones en línea, indica que las camisas vienen de Armatambo, Vista Alegre, Ñaña, Monterrico (Valle de Rímac), Pachacamac (Valle de Lurín), así como Chuquitanta (Valle de Chillón) y Ancón.

\section{Taparrabos}

Se ha podido reconocer accesorios tipo delantal para los taparrabos, que tienen la forma de campana invertida y están tejidos en tapiz, como piezas de vestuario que hacen juego con las camisas en tapiz. Aunque no están presentes en el contexto de Armatambo, la combinación de colores, el repertorio de figuras, la banda amarilla con flecos y las características técnicas de este accesorio son compartidas con las camisas de tapiz Ychsma. Un ejemplo en miniatura aún sigue unido a un extremo de un taparrabo, tipo Ychsma ${ }^{22}$. Presumiblemente, el panel en tapiz estaba colocado en la zona frontal, con el extremo angosto del panel en tapiz y la franja amarilla colgando hacia abajo. La limitada información sobre la procedencia de la muestra indica que los ejemplos provienen de Surco (Valle de Rímac) y Márquez (Valle de Chillón).

El taparrabo, que se acampana en ambos extremos, es una prenda que llevaban los hombres Ychsma, como se ilustra en el contexto descrito aquí (Figs. 24, 26 y 27). Taparrabos de esta forma son tejidos con hilos de alta torsión, que son un cabo hilado en S. Algunos tienen patrones insertados con tramas suplementarias en el extremo más ancho. Probablemente las zonas triangulares con dibujos cubrieron las nalgas y el extremo más estrecho formó un delantal en la parte frontal. Los taparrabos fueron confiablemente reportados desde una serie de lugares entre los valles del Rímac y Chincha, así como de Ancón ${ }^{23}$. Aquellos con dibujos provienen de los valles de Rímac, Lurín y de Ancón, pero no de los valles más al sur. Las técnicas de diseño con tramas, como brocados, tramas suplementarias embutidas ("inlay") (Fig. 24), y tramas discontinuas (Fig. 26), se emplean para la confección de patrones en el extremo más ancho. Como se describió anteriormente, algunos ejemplares tenían un panel en tapiz, o delantal, unido al extremo más angosto del taparrabo.

21 Para las camisas tapiz con tramas de camélido, véase Mayer 1969: Lámina 7 (CAI 55.1680); Taullard 1949: figura 141 (Pachacamac); MdqB 71.1964.86.148 (d’Harcourt colección); AMNH B/8566 (Monterrico, colección Gaffron); MMA 82.1.2 (dice que es de Ancón); MNAA RT 2107; PMH 15-41-30/86882 (Ñaña, valle de Rímac); SAM PC40.31; y TM 1966.7.35.

22 Para taparrabos delantales en tapiz, véase Bjerregaard 2002: 105 (NMD 0.4405); Stone-Miller, 1992: \#178 (MFAB 30.257); AMNH B/8560 (Márquez, Valle de Chillón, colección Gaffron); MNAA RT 3589; NMNH 233537 (Surco, ex-colección Bandelier); y TM 91.4.

23 Para taparrabos, véase Feltham 2002: Figura 7 (Pachacamac); Frame et al. 2004: Figura 17 (Rinconada Alta); Hyslop y Mujica 1992: Figura 16 (Surco, AMNH B/1259, colección Bandelier); Montell 1929: Figura 71B (RMS 05.17.134); Osborne 1950 (siete desde el valle del Rímac, once del Valle de Cañete, y dos del Valle de Chincha); Daniel Guerrero (excavación de Rinconada Alta, 098.1); AMNH B/1073 a, b, y c (Surco, colección Bandelier); AMNH B/1215 (Surco, colección Bandelier); AMNH B/1233 A y B (Surco, colección Bandelier); AMNH B/4184 (Ancón, colección Bandelier); SM 363.02.2057 (Excavación en Armatambo: Ruales, Vallejo y Tosso); SM 363.02.2055 (Excavación en Armatambo: Ruales, Vallejo y Tosso); y UPM 32702 (Pachacamac, colección Uhle). 


\section{Vinchas}

Otro artículo en tapiz, usado por los hombres, es una vincha rellenada ${ }^{24}$. Las vinchas se hacen en dos partes: una banda en tapiz y un paño cuadrado ligero, en ligamento llano. Las urdimbres y tramas del tejido ligero son de un cabo hilado en S. El cuadrado se pliega una vez en diagonal, para luego doblarse varias veces sobre la misma diagonal formando una almohadilla de tela del mismo ancho que la banda en tapiz, a la que se cose. La extensión del tapiz, más allá del acolchado, se dobla y se cose en los extremos de menor anchura de la vincha. Las vinchas en tapiz pueden ser de algodón con algunas figuras bordadas añadidas (Fig. 30), pero la mayoría de muestras reunidas tienen por lo menos algunas tramas en fibra de camélido teñido. Motivos entrelazados o geométricos y motivos figurativos de

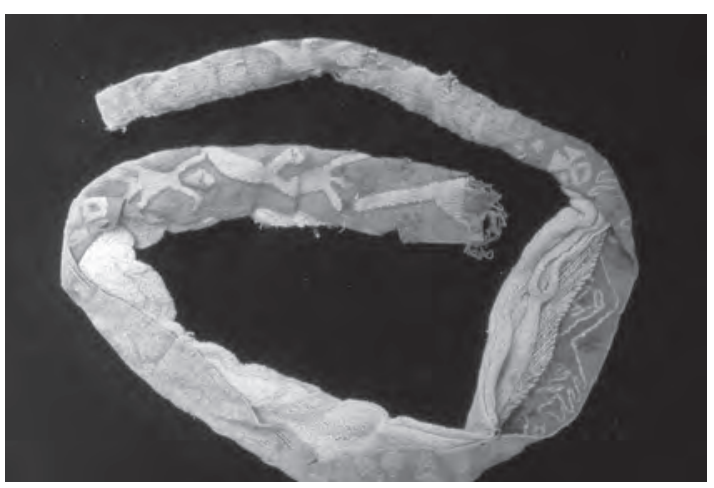

Figura 30. Vinchas rellenadas se pueden encontrar en $\mathrm{mu}$ chos sitios de los valles de Rímac y Lurín. Esta banda de tapiz fue hallada en el compartimiento " $I$ ", en el mismo sector del contexto de Armatambo descrito en este artículo. 89 (la urdimbre está a lo largo) x $4 \mathrm{~cm}$. SM 363.02.2043. animales o plantas se repiten a lo largo de las vinchas. Este tipo de vincha fue reportado en Armatambo, Rinconada Alta, Surco, Maranga, Vista Alegre y Pachacamac (valles de Rímac y Lurín), así como en Márquez y El Paraíso (valle de Chillón) y Ancón. Una banda en tapiz ranurado encontrado en el relleno de la tumba del contexto de Armatambo (Fig. 3) puede ser parte de una vincha, aunque es más ancho que la mayoría.

\section{Mantos en Tapiz}

Grandes mantos en tapiz también forman parte del repertorio de las prendas de estilo Ychsma, aunque ninguno de ellos estuvo presente en el fardo de Armatambo. Varios mantos en tapiz, tejidos con tramas de fibra de camélido teñidas, son confeccionados en paneles (Jiménez Borja 1999: Láminas 3 y 4). Un característico tipo de felino de uno de los ejemplos lleva contornos dentados en la espalda y en la cabeza. Su relación con el estilo Ychsma se ve confirmada por los fragmentos de una camisa de Pachacamac, que lleva la misma figura (Taullard 1949: Figura 141). Un felino ligeramente diferente se repite en otro ejemplar (Jiménez Borja 1999: Láminas 3 y 4), y esta figura se encuentra en un muestrario en tapiz (VanStan 1954: Lámina II). El muestrario también incluye varias figuras que se elaboran en las camisas tapiz Ychsma, confirmando la afiliación Ychsma de los mantos y el muestrario. Algunos mantos calados, que son de ligamento de gasa, también pertenecen a este estilo. Una escena compleja donde participan seres humanos y posiblemente literas fue tejida con tramas suplementarias compactas sobre una base de gasa, en un manto que viene del mismo contexto de Ancón que contiene dos camisas en tapiz de estilo Ychsma ${ }^{25}$. Este fragmento de manto tiene un borde con plumas en tapiz cuyas puntas

24 Para vinchas rellenadas, ver Eeckhout 1998: Figura 15 (Pachacamac); Feltham 2002: Figura 8 (Pachacamac); Jijón y Caamaño 1949: Lámina LXIX, a la izquierda (Maranga); Smith 1926: Lámina III, número 2 (cerca de Lima, V \& AM); Luisa Díaz (Armatambo de 2003, dos hallazgos de superficie); Daniel Guerrero (Excavación en Rinconada Alta, 809.1, 809.4, 816.11, 816.12, 823.7 y 823.8); AMNH B/1328 (Surco, colección Bandelier); AMNH B/4659; AMNH B/8632 (Márquez, colección Gaffron); AMNH B/8682; AMNH B/8742 (El Paraíso, colección Gaffron); AMNH B/9630 (Ancón, colección Bandelier); MdqB 71.1933.0.271.15; MMA 28.64.11; MMA 29.146.4; MNAA RT 3610; MNAA RT 4124; MNAA RT 12280; MNAA RT 29046; PachSM 1132T-54 (Pachacamac); PMH 4677-30/11027 (Vista Alegre); PMH 46-77-30/10899; SM 363.02.2107 (Excavación en Armatambo: Ruales, Vallejo y Tosso); SM 363.02.2052 (Excavación en Armatambo: Ruales, Vallejo y Tosso); y UPM 32577 (Pachacamac, colección Uhle).

25 NMNH 133385, B-0 y B-1 (Ancón). 
sobresalen, una característica especial presente en un manto del fardo de Armatambo (Fig. 16c). La fibra de algodón, la gama de colores, la iconografía y las características técnicas coinciden con los textiles del contexto de Armatambo, y los textiles Ychsma en general. Un gran tapiz rectangular de Armatambo, que fue tejido en una sola pieza, representa buceadores, remadores en balsas de totora, cangrejos, peces y aves (Lumbreras 1974: Figura 194) ${ }^{26}$. La iconografía, colores, fibras y características técnicas indican que también es de estilo Ychsma, pero el tamaño del panel sugiere que fue tejida en un telar vertical, probablemente introducido a la costa por los Incas.

\section{Mantos Brocados}

Los brocados son otra clase de tejidos que predominan en el estilo Ychsma, y los mantos de tres paneles con figuras de gran escala son lo más distintivo de ellos (Figs. 7a, 10b, 15a, 19a y 21a). Las detalladas figuras, que a menudo ocupan todo el ancho de un panel, se repiten en filas y columnas y presentan diferencias de color. Las figuras sobre los mantos de algodón se tejen en crema, café, tonos azules, varios tonos de marrón, ocasionalmente verde, ladrillo, rosa y amarillo ${ }^{27}$. Las urdimbres son Z-2S y las tramas suplementarias son generalmente un par de cabos hilados en Z. Las tramas de tela base son más variables (S, $\mathrm{Z}, \mathrm{o} \mathrm{Z}-2 \mathrm{~S}$ ). Las tramas suplementarias en este tipo de brocado flotan por encima de cinco urdimbres y se sujetan por debajo de una urdimbre. La iconografía puede ser descrita como figurativa en algunos casos, pero parece ser narrativa en otros, donde las figuras se muestran en una escena específica con otras figuras. Las escenas incluyen arquitectura con rasgos escalonados (Fig. 21a), botes y balsas (Figs. 31a y b). Buceadores horizontales con canastas para recolección debajo del tronco, se ubican claramente en un entorno marino (Fig. 31C). Grandes mantos de este tipo, que serán detalladamente discutidos en otra parte (Frame s.f.), se han recuperado en Armatambo (Figs. 31b y d) y Pachacamac en los valles de Rímac y Lurín, y en Márquez (Valle de Chillón).

El brocado es una técnica que se teje más rápidamente que el tapiz, y una serie de brocados parecen imitar los mantos Ychsma con parches en tapiz ${ }^{28}$. Aunque no estaban presentes en el contexto Armatambo descrito aquí (al lado del pequeño fragmento en Fig. 15a), este grupo de brocados están estrechamente vinculados, técnicamente y estilísticamente, a los textiles del fardo. Las figuras más comúnmente representados son los peces, pero las aves también pueden ser representadas. La mayoría están elaborados completamente con hilos de algodón, y las tramas suplementarias flotan por encima de un número impar de urdimbres y se sujetan por debajo de una sola urdimbre. Este tipo de tela fue reportado en Armatambo, Pachacamac y Rinconada Alta.

Dos telas brocadas del fardo de Armatambo (Figs. 8 y 20), aunque también fueron elaboradas con tramas suplementarias hiladas en $Z$, son estructuralmente distintos de los que acabamos de describir. Las tramas suplementarias flotan por encima de un número par de urdimbres y se sujetan por debajo de dos urdimbres. El primer ejemplo es un manto elaborado con muchos paneles estrechos, en las que se representa una escena de buceo en un estilo más lineal. Varios fragmentos de estructura similar, con la

26 SM363.02.1422 (Armatambo, colección Chávez Ballón).

27 Para grandes figuras en brocado ver Hyslop y Mujica 1992: Figura 13, (Surco, AMNH B/4523, colección Bandelier); Schmidt 1929: 506 (Pachacamac, EMB, colección Gretzer); excavación de Luisa Díaz (Armatambo, U13 139.5-D); AMNH B/4552 (Surco, colección Bandelier); AMNH B/8600 (Márquez, colección Gaffron); AMNH B/8605 (Márquez, colección Gaffron); SM 363.02.1994 (Excavación en Armatambo: Ruales, Vallejo y Tosso); y UPM 32664a (Pachacamac, colección Uhle).

28 Para brocados que imitan textiles con parches en tapiz, véase Feltham 1989: Figura 19; de Lavalle y García 1988: 257; Schmidt 1929: 509 (Pachacamac, EMB, colección Gretzer); Smith 1926: Lámina VII (cerca de Lima, V \& AM); excavación de Daniel Guerrero (Rinconada Alta, RA 955); MfVB IVc4110; PurSM RT 01262; UPM 32656 (Pachacamac, colección Uhle); y UPM 32657 (Pachacamac, colección Uhle). 
misma o diferente escena, se han recuperado en Pachacamac ${ }^{29}$. El segundo ejemplo tiene un tablero de ajedrez con cuadros llanos y cuadros con dibujos. Brocados similares de algodón fueron recuperados en Huaquerones (Valle de Rímac) y en Pachacamac ${ }^{30}$.

Los textiles confeccionados con la técnica de brocado son quizás los más numerosos en los paños Ychsma. Las subcategorías de brocados discutidas aquí incluyen algunos, pero no todas, las variantes de brocados Ychsma. Los brocados con figuras de menor escala y figuras que se entrelazan en diagonales son probablemente subcategorías adicionales, pero no son suficientemente distintos de los brocados de otros estilos de la costa, como para definirlos sin ejemplos de contextos sólidos.

\section{Vestidos}

Las prendas femeninas de estilo Ychsma pueden ser descritas. Aunque la prenda usada por la mujer sacrificada en la tumba estaba demasiado deteriorada para conservarla, un fragmento con pliegues de un vestido estaba en el relleno de la tumba (Fig. 6). Ejemplos completos de vestidos de otros contextos y colecciones ${ }^{31}$ ilustran que los vestidos Ychsma tienen una falda larga, un canesú corto con pliegues y aberturas horizontales para la cabeza y las manos en el borde superior. Pliegues estrechos, flanqueando una sección plana en el centro delantero de la blusa, son un rasgo distintivo. La costura curva en la cintura es otro rasgo distintivo en varios vestidos (Fig. 32b). El exceso de tela del canesú, que ha resultado de la costura curva, es dejada suelta en el interior de la vestimenta (Fig. 32a). Algunos vestidos son elaborados de muchas piezas de tela llana, y las secciones plisadas pueden mostrar tres o más colores, así como diseños dispuestos en los bordes. Tonos naturales de algodón fueron empleados para la mayoría de los vestidos y sólo algunas veces incorporaron listas de color, paños teñidos, o figuras brocadas (Frame 2010: Figura 16). En los vestidos de estilo Ychsma, los pliegues estrechos son cosidos tanto en la costura del hombro como en la costura de cintura, en contraste con otros estilos de la costa donde pliegues más sueltos se fijan sólo en la costura del hombro. En general, al igual que los vestidos de la costa, las urdimbres están orientadas horizontalmente. Las aberturas para las manos en algunos vestidos Ychsma son demasiado pequeños como para que una mano humana pueda pasar a través de él, lo que podría sugerir que algunos vestidos se hicieron, o al menos fueron remodelados, para cubrir el exterior de fardo de la momia. Vestidos, o fragmentos característicos de ellos, fueron reportados en la muestra comparativa de Armatambo, Huallamarca, Surco, Rinconada Alta, el Fundo Pando (Maranga) en el Valle de Rímac y de Pachacamac en el Valle de Lurín.

Otros textiles incluidos en el contexto de Armatambo, como el arte plumario y teñido en reserva (Figs. 12, 13, 14 y 23) no son suficientemente distintivos, ni técnicamente ni estilísticamente, para separarlos de productos textiles similares de otras regiones costeñas. Las prendas llanas en el fardo se ajustan a la construcción Ychsma de camisas de dos paños y mantos de tres paños, pero estas características son compartidas por otros estilos costeños. El manto amarillo bordado con aves (Fig. 17) por el contrario, es el único en su clase.

29 Para brocados con escenas, véase Schmidt 1910: Figura 25 (Pachacamac); Uhle 1991: 67, Figura 90, UPM 32655 (Pachacamac, colección Uhle); y UPM 32662 (Pachacamac, colección Uhle).

30 Para brocados con diseños en ajedrezados, véase AMNH SAT 121; MNAA RT 20747; PachSM s/n; PurSM 001263 (Huaquerones); y UPM 32689 (Pachacamac, colección Uhle).

31 Para los vestidos, véase Jijón y Caamaño 1949: Lámina LXIII, 6 (Maranga); Prümers 1998: (Figura 2, Huallamarca, PurSM 1627, Figuras 6 y 7 (PurSM 1632), Figura 9 (Fundo Pando [Maranga], Lima, IRA \#06854), Figura 15 (EMB VA 66753) y Figura 16 (EMB VA 34072); Uhle 1991: 68, Figura 94 (Pachacamac); Excavación de Daniel Guerrero (Rinconada Alta, RA 704.12); AMNH B/1267 (Surco, colección Bandelier); AMNH B/1273 (Surco, colección Bandelier); AMNH B/1293 (Surco, colección Bandelier); AMNH B/4554 (Surco, colección Bandelier); MNAA RT 35228 (Excavación en Armatambo: Daniel Guerrero); PurSM 0852; y SM 363.02.1978 (Excavación en Armatambo: Ruales, Vallejo y Tosso). 


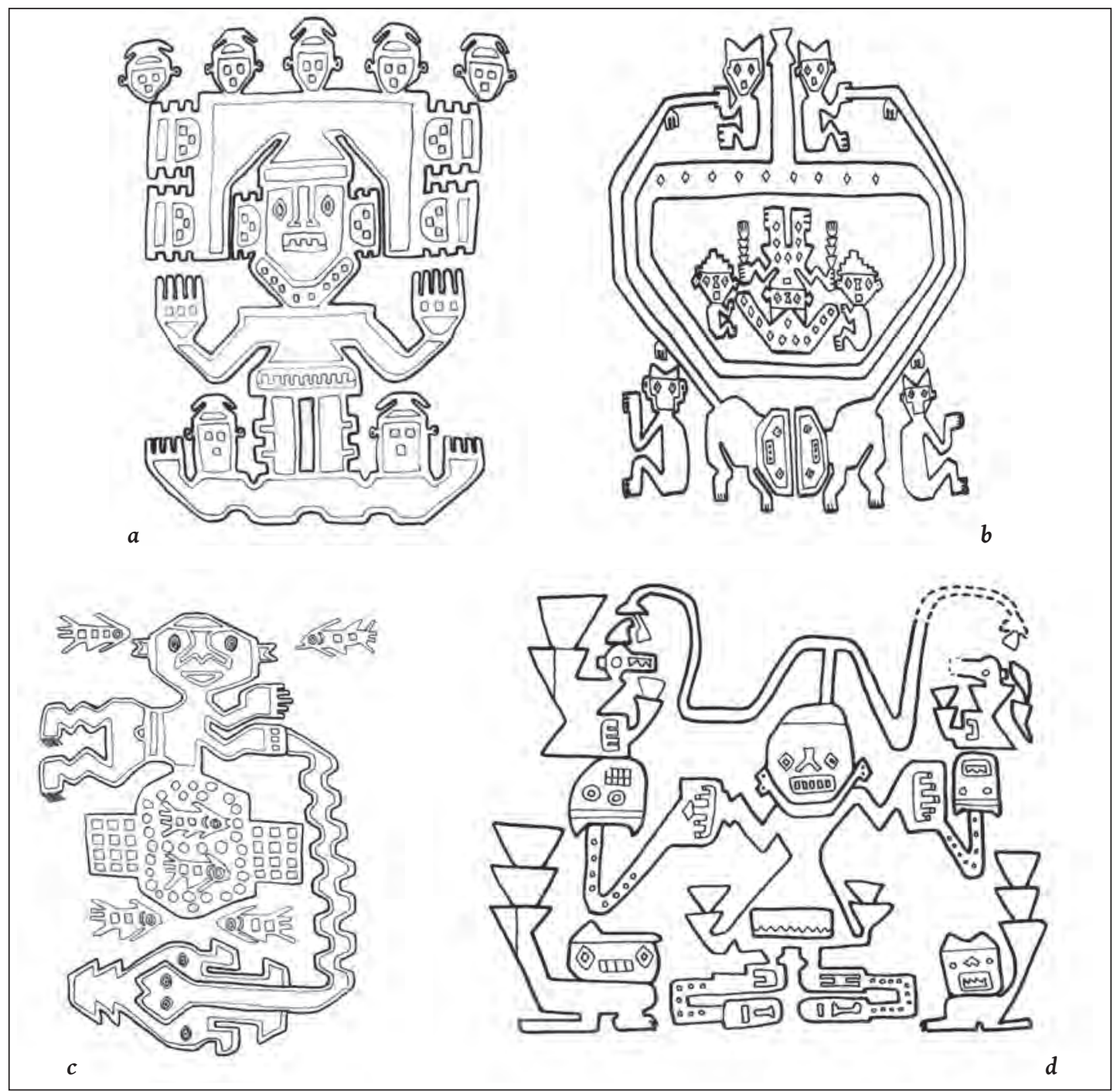

Figuras $31 a, b, c y d$. Corresponden a figuras hechas con la técnica del brocado procedentes de cuatro mantos distintos, hallados en contextos de diferentes sitios de la costa central. a. AMNH B/8600, Márquez; $320 \times 180 \mathrm{~cm}$. b. excavación de Luisa Díaz, Armatambo 2000, U 13, 139.5-D; 295 x 170. c. AMNH B/8605, Márquez; 327 x 186. d. SM 363.02.1994, excavación de Ruales, Vallejo y Tosso, Armatambo 1982, Sector D-1, Pozo 8; más de 290 × $206 \mathrm{~cm}$.

\section{LA ESFERA DE INTERACCIÓN YCHSMA}

El único contexto de Armatambo proporciona una amplia base de datos para describir el estilo de los textiles Ychsma durante el Horizonte Tardío. La muestra comparativa confirma los atributos del estilo y agrega nuevas variantes de los tipos de prendas de vestir, la iconografía, las técnicas, fibras y colores que están representados por los textiles del contexto de Armatambo. La información proveniente de la muestra comparativa indica que los textiles Ychsma, y probablemente la población Ychsma, se concentraron en las partes bajas de los valles de Rímac y Lurín, pero también hicieron incursiones hacia el norte hasta el valle de Chillón, en sitios como Márquez y Chuquitanta, al menos en algún momento en el tiempo (Fig. 29). Un número significativo de textiles Ychsma también se registran hasta Ancón, don- 


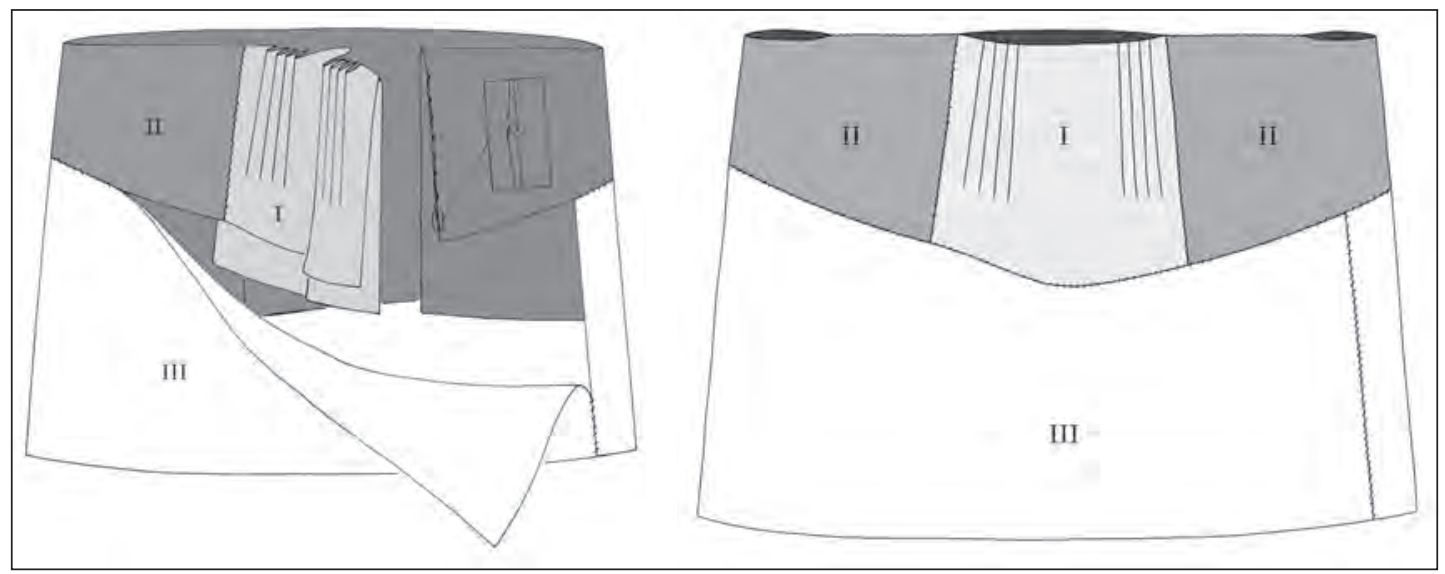

Figuras 32 a y b. Diagrama mostrando la construcción del vestido Ychsma (a), que tiene los pliegues en el canesú y la costura encorvada en el talle (b). Reproducido de Prümers 1998: Figura 3.

de se encuentran textiles de diferentes estilos (Reiss y Stübel 1880-1887). Al igual que los de Maranga, en el Valle de Rímac, que incluye muchos tejidos que parecen ser de estilo Chancay (Jijón y Caamaño 1949), los variados estilos que se encuentran en Ancón puede indicar permeabilidad y tal vez fluctuaciones, entre los límites geográficos de grupos étnicos en la costa central. Periódicamente, las poblaciones también pudieron cruzar las fronteras para los ritos ceremoniales o el comercio, particularmente en los sitios más importantes, como Ancón, Maranga y Pachacamac. La variedad de estilos de tejidos de Pachacamac en el valle de Lurín (Schmidt 1910 y 1929; Uhle 1991) indican que las personas y los textiles se movían mucho más allá de su tierra natal, durante extensos periodos, para visitar los santuarios más importantes. Basada en la información de procedencia disponible, para lo que ahora puede ser identificado como textiles Ychsma, la esfera de influencia Ychsma se extendió más allá de los valles de Rímac y Lurín, hacia el valle bajo de Chillón y al menos hasta Ancón. Aunque los mecanismos y los acontecimientos que produjeron el mosaico de estilos textiles que sobrevivieron en sitios de la costa central durante los últimos periodos son poco conocidos, los datos del contexto de Armatambo hacen posible separar de otros estilos los principales tipos de prendas textiles de estilo Ychsma.

\section{Agradecimientos}

Nuestra profunda gratitud al personal del Museo de Arqueología y Antropología de la Universidad Nacional Mayor de San Marcos, en Lima, que facilitó el estudio inicial de los tejidos de Armatambo, y al personal de los siguientes museos que facilitaron el estudio comparativo posterior del material: Instituto de Arte de Chicago, el Museo Americano de Historia Natural (Nueva York), Dumbarton Oaks (Washington, DC), el Instituto Riva-Agüero (Lima), el Museo de Arte Metropolitano (Nueva York), el Museo Nacional de Arqueología, Antropología e Historia del Perú (Lima), el Museo Nacional de Historia Natural (Smithsonian Institution, Washington), el Museo de Sitio de Pachacámac, el Museo de Arqueología y Etnología Peabody de la Universidad de Harvard (Cambridge), el Museo de Sitio de Puruchuco, el Museo Textil (Washington, DC) y el Museo de Arqueología y Antropología de la Universidad de Pennsylvania (Philadelphia). Agradecemos la colaboración de los colegas Miguel Cornejo, Luisa Díaz, Peter Eeckhout, Jane Feltham, Daniel Guerrero, Patricia Landa, Pedro Novoa, Heiko Prümers Ann Rowe y el Departamento Textil del MNAAHP, en particular Haydeé Grández Alejos, por su trabajo en la traducción. Una versión del articulo en inglés ha sido publicado en la revista Nawpa Pacha (Frame et al. 2012). El primer autor desea agradecer a Dumbarton Oaks por concederle una beca en el año 2001, la misma que contribuyó en la acumulación de datos comparativos en los museos de EE.UU;; y a la Fundación Selz, que financió varios viajes al Perú con el propósito de estudiar los textiles Ychsma. 


\section{Abreviaturas empleadas}

AIC Instituto de Arte de Chicago

AMNH Museo Americano de Historia Natural, Nueva York

BM Museo Británico, Londres

CMA Museo de Arte de Cleveland

EMB Museo Etnológico, Staatliche Museen zu Berlin

IRA Instituto Riva-Agüero, Lima

MdqB Musée du quai Branly, Paris

MfVB Museo für Völkerkunde, Basel

MFAB Museo de Bellas Artes, Boston

MMA Museo de Arte Metropolitano, Nueva York

MNAA Museo Nacional de Arqueología, Antropología e Historia del Perú, Lima

NMD Museo Nacional de Denmark, Copenhagen

NMNH Museo Nacional de Historia Natural, Fundación Smithsonian, Washington

PachSM Museo de sitito de Pachacamac

PMH Museo de Arqueología y Etnología Peabody, Universidad de Harvard

PurSM Museo de sitio Puruchuco

RMS Riksmuseum, Stockholm

SAM Museo de Arte de Seattle

SM Museo de Arqueología y Antropología de la Universidad Nacional Mayor de San Marcos

TM Museo Textil, Washington, D.C.

UPM Museo de Arqueología y Antropología de la Universidad de Pennsylvania, Philadelphia

V\&AM Victoria and Albert Museum, Londres.

\section{BiBLIOGRAFÍA}

BENSON, Elizabeth

1997 Birds and beasts of ancient Latin America. Gainesville: University Press of Florida.

BIRD, Junius

1962 "Art and life in old Peru". Curator 5(2):145-210. New York: American Museum of Natural History.

BJERREGAARD, Lena

2002 Pre-Columbian Woven Treasures in the National Museum of Denmark. Copenhagen: Nacional Museum of Denmark.

COBO, Bernabé

1882 Historia de la fundación de Lima [1639]. Colección de Historiadores del Perú. Lima: Imprenta Liberal.

COCK, Guillermo

2002 "Inca Rescue". National Geographic 201(5): 78 - 91.

COCK, Guillermo, y Carmen GOYCOCHEA DÍAZ

2004 "Puruchuco y el cementerio Inca de la Quebrada de Huaquerones". En: Puruchuco y la sociedad de Lima: Un homenaje a Arturo Jiménez Borja. Editado por Luis Felipe Villacorta, pp. 179-197. Lima: Consejo Nacional de Ciencia y Tecnología CONCYTEC.

CONKLIN, William

1990 "Architecture of the Chimu: memory, function, and image". En: The Northern Dynasties: kingship and statecraft in Chimor. Editado por Michael Moseley y Alana Cordy-Collins, pp. 43 - 74. Washington: Dumbarton Oaks.

DÍAZ, Luisa y Patricia LANDA

2009 "Khipus y tukapus de Armatambo". En: Actas del IVJornadas Internacionales sobre Textiles Precolombinos. Editado por Victòria Solanilla Demestre, pp. 345 - 359. Grup d'Estudis Precolombins, Departament d'Art de la Universitat Autònoma de Barcelona, España. 
DÍAZ, Luisa y Francisco VALLEJO

2002a "Armatambo y el dominio incaico en el valle de Lima". En: Identidad y transformación en el Tawantinsuyu y en los Andes coloniales. Perspectivas arqueológicas y etnohistóricas, primera parte, Boletín de Arqueología PUCP no. 6: 355-374. Editado por Peter Kaulicke, Gary Urton y Ian Farrington. Lima: Pontifica Universidad Católica del Perú.

2002b "Identificación de contextos funerarios Ichma en Armatambo". Arqueología y Sociedad 14: 47-75. Lima: Museo de Arqueología y Antropología de la Universidad Nacional Mayor de San Marcos.

2004 "Variaciones culturales en el valle de Lima durante la ocupación incaica". Chungará, Revista de Antropología Chilena 36(2): 295-302. Arica.

2005 "Clasificación del patrón funerario Ychsma identificado en Armatambo y La Rinconada Alta". En: Muerte y evidencias funerarias en los Andes Centrales: avances y perspectivas, Corriente Arqueológica I: 223-322. Lima: Universidad Nacional Federico Villarreal.

DONNAN, Christopher

1986 "An elaborate textile fragment from the major quadrangle". En: The Pacatnamu Papers, volumen 1: 109-1116. Editado por Christopher Donnan y Guillermo Cock. Los Angeles: Museum of Cultural History, University of California.

EECKHOUT, Peter

1998 "Offrandes funéraires à Pachacamac et Pampa de las Flores: Exemples des relations entre les côtes nord et centrale du Pérou à l'époque pré-inca", Baessler-Archiv, Neue Folge, Band XLVI, Heft 1: 165229, Berlin.

1999 "Pachacamac, pirámide con rampa III: nuevos datos, nuevas perspectivas". Boletín del Instituto francés de estudios andinos 28(2): 169-214, Lima.

2002 "Hallazgo y desenfardelamiento de un bulto funerario de Pachacamac, costa central de Perú". En: Actas de las II Jornadas internacionales sobre textiles precolombinos. Editado por Victòria Solanilla Demestre, pp. 135-152. Grup d'Estudis Precolombins, Departament d'Art de la Universitat Autònoma de Barcelona, España.

ENGELSTAD, Helen

1980 “The Big Fishes from Pachacamac, Peru”. Folk Vol. 21-22 (1979/80): 45-52, Copenhagen: Denmark. FELTHAM, Jane

1989 "Peruvian textiles", Shire Ethnography Series. Aylesbury: Shire Publications.

2002 "Los tejidos de la pirámide III de Pachacámac". En: Actas de la II Jornadas Internacional sobre Textiles Precolombinos. Editado por Victoria Solanilla, pp. 95-114. Grup d'Estudis Precolombins, Departament d'Art de l'a Universitat Autònoma de Barcelona, España.

s.f. "El mensaje que querían comunicar los Incas por medio de los textiles de Pachacamac durante el Horizonte Tardío". Ponencia presentada en el Simposio Internacionale: Textiles, Techne and Power in the Andes, London, March 15-17, 2012.

FRAME, Mary

2010 "Vestidos de la nobleza en los Andes centro y centro-sur en los periodos tardíos". En: Señores de los Imperios del Sol, compilador Krzysztof Makowski, pp. 239-259. Banco de Crédito del Perú, Lima.

s.f. Brocades from the vicinity of Lima in the time of the Incas (En prensa). Santiago: Comite Nacional de Conservación Textil, XXV edición de aniversario del CNCT.

FRAME, Mary, Francisco VALLEJO, Mario RUALES y Walter TOSSO

2012 "Ychsma textiles from a Late Horizon burial at Armatambo". Ñawpa Pacha 32 (1):43-84. Berkeley: Institute of Andean Studies.

FRAME, Mary, Daniel GUERRERO, María del Carmen VEGA DULANTO y Patricia LANDA CRAGG

2004 "Un fardo funerario del Horizonte Tardío del sitio Rinconada Alta, Valle del Rimac". En: Arqueología de la Costa Central del Perú en los Periodos Tardíos, Boletín del Instituto francés de estudios andinos 33 (3): 815-860. Lima: IFEA.

GUERRERO, Daniel

2004 "Cronología cerámica y patrones funerarios del valle del Rímac: una aproximación a los periodos tardíos". En: Puruchuco y la sociedad de Lima: Un homenaje a Arturo Jiménez Borja. Editado por Luis Felipe Villacorta, Luisa Vetter y Carlos Auseho, pp. 157-177. Lima: CONCYTEC. 
D'HARCOURT, Raoul

1962 Textiles of ancient Peru and their techniques. Editado por Grace Denny y Carolyn Osborne. Seattle: University of Washington Press.

D'HARCOURT, Raoul y Margarite D'HARCOURT

1924 Les tissus indiens du vieux Pérou. Paris: Editions Albert Morancé.

HAUN, Susan y Guillermo COCK

2010 "A bioarchaeological approach to the search for mitmaqkuna". En: Distant provinces in the Inka Empire. Editado por Michael Malpass y Sonia Alconini, pp. 193-220. Iowa City: University of Iowa Press.

HYSLOP, John y Elías MUJICA

1992 "Investigaciones de A.F. Bandelier en Armatambo (Surco) en 1892". Gaceta Arqueológica Andina VI(22): 63-86. Lima: Instituto Andino de Estudios Arqueológicos.

JIJÓN Y CAAMAÑO, Jacinto

1949 Maranga, contribución al conocimiento de los aborígenes del Valle de Rímac, Perú. Quito: La Prensa Católica.

JIMÉNEZ BORJA, Arturo

1999 “Textilería del santuario de Pachacamac". En: Tejidos Milenarios del Perú. Editado por J.A. de Lavalle y R. de Lavalle de Cardenas, pp. 491-503. Lima: AFP Integra.

JIMÉNEZ, María Jesús

2006 "Avances en la caracterización de los estilos textiles de finales del Intermedio Tardío y comienzos del Horizonte Tardío en los Andes Centrales: La colección Maiman de tejidos precolombinos". En: Actas de la III Jornadas Internacionales sobre Textiles Precolombinos. Editado por Victòria Solanilla Demestre, pp. 241-259. Grup d'Estudis Precolombins, Departament d'Art de l'a Universitat Autònoma de Barcelona, España.

2009 Tradición de tradiciones: Los tejidos prehispánicos del Museo de América de Madrid. Madrid: Ministerio de Cultura de España.

KULA, Gulli

1991 "A Study of surface-collected Chancay textiles". En: Estudios sobre la cultura Chancay, Perú. Editado por A. Krzanowski, pp. 263 - 284. Kraków: Universidad Jaguelona.

DE LAVALLE, José Antonio, ed.

1988 Culturas precolombinas Chimu, colección arte y tesoros del Perú. Lima: Banco de Crédito del Perú.

DE LAVALLE, José Antonio y José Antonio GONZÁLEZ GARCíA, eds.

1988 Arte textil del Perú. Lima: Industria Textil Piura.

DE LAVALLE, José Antonio y Werner LANG, eds.

1977 Arte precolombino, primera parte, arte textil y adornos. Lima: Banco de Crédito del Perú.

1979 Arte precolombino, tercera parte, pintura, colección arte y tesoros del Perú. Lima: Banco de Crédito del Perú.

1982 Culturas precolombinas Chancay, colección arte y tesoros del Perú. Lima: Banco de Crédito del Perú.

LECHTMAN, Heather

1977 "Style in technology - some early thoughts". En: Material culture: styles, organization, and dynamics of technology. Editado por Heather Lechtman y Robert S. Merrill, pp. 3-20. St. Paul: West Publishing Company.

LUMBRERAS, Luis

1974 The peoples and cultures of ancient Peru. Traducido por Betty J. Meggars. Washington, D.C.: Smithsonian Institution Press.

MAYER, Christa Charlotte

1969 Masterpieces of western textiles from the Art Institute of Chicago. Chicago: The Art Institute of Chicago.

MONTELL, Gösta

1929 Dress and ornaments in ancient Peru. London: Oxford University Press.

1993 The Inka empire and its Andean origins. Abbeville Press, New York, London, y Paris. 
OSBORNE, Carolyn

1950 "Shaped breechcloths from Peru". Anthropological records 13(2): 157-188. University of California, Berkeley y Los Angeles.

PRÜMERS, Heiko

1998 Un nuevo tipo de camisa del antiguo Perú. En: 50 años de estudios americanistas en la Universidad de Bonn. Nuevas contribuciones a la arqueología, etnohistoria, etnolingüistica y etnografía de las Américas. Bonner Amerikanistische Studien 30: 217-237. Mark \& Schwaben.

s.f. Hojas de trabajo inéditas con descripciones técnicas de los textiles del fardo de Armatambo.

REINA, Ruben E. y Kenneth M. KENSINGER, eds.

1991 The gift of birds: featherwork of native South American peoples. Philadelphia: The University Museum of Archaeology and Anthropology, University of Pennsylvania.

REISS, Wilhelm y Alfons STÜBEL

1880-1887 The necropolis of Ancon in Peru: a contribution to our knowledge of the culture and industries of the empire of the Incas, being the results of excavations made on the spot. 3 vols. Traducido por A.H. Keane. Berlin: A. Ascher \& Co.

ROSTWOROWSKI DE DIEZ CANSECO, María

1989a "Breve ensayo sobre el señorio de Ychma". En: Costa Peruana prehispánica, pp. 71-78. Lima: IEP.

1989b “Las etnías del Valle del Chillón”. En: Costa Peruana prehispánica, pp. 23-69. Lima: IEP.

1990 "Las macroetnias en el ámbito andino". Allpanchis 22 (35-36): 3-28. Cusco: Instituto de Pastoral Andina.

ROWE, Ann Pollard

1984 Costumes and featherwork of the lords of Chimor: textiles from Peru's north coast. Washington D.C.: Textile Museum.

1992 "Provincial Inca tunics of the South Coast of Peru". Textile Museum Journall, vol. 31, pp. 5-52.

1996 "Three spindles". Andean Art at Dumbarton Oaks, vol. 2. Editado por Elizabeth H. Boone, pp. 445 - 7. Washington D.C.: Dumbarton Oaks.

2006 “Términos textiles en castellano”. En:Actas dela IIIJornadas Internacionales sobre Textiles Precolombinos. Editado por Victòria Solanilla Demestre, pp. 443-469. Grup d'Estudis Precolombins, Departament d'Art de la Universitat Autònoma de Barcelona, España.

RUALES, Mario

s.f. 1 Inventario general de los materiales del sitio de Armatambo. Lista de artefactos puesto en el Museo de Aqueología y Antropología de la Universidad Nacional Mayor de San Marcos.

s.f.2 Inventario del material recuperado. Lista de artefactos excavados de todos compartamientos de la excavación de Armatambo.

RUALES, Mario, Walter TOSSO y Francisco VALLEJO

1983 Informe de las excavaciones de rescate del sector D1 de Armatambo (1983). Informe técnico presentado al Instituto Nacional de Cultura, Lima.

SCHMIDT, Max

1910 “Über altperuanische gewebe mit szenehaften darstellungen”, Baessler-Archiv Band 1, Heft 1. Berlin: Museum für Völkerkunde.

1929 Kunst und kultur von Peru. Berlin: Propyläen-Verlag.

SMITH, A.D. Howell

1926 Brief guide to the Peruvian textiles, Victoria and Albert Museum. London: Victoria and Albert Museum.

STONE-MILLER, Rebecca

1992 To weave for the sun: Andean textiles in the Museum of Fine Arts, Boston. Boston: Museum of Fine Arts.

TAULLARD, Alfredo

1949 Tejidos y ponchos indígenas de Sudamérica. Buenos Aires: Guillermo Kraft.

UBBELOHDE DOERING, Heinrich

1952 The art of ancient Peru. New York: Frederick A. Praeger. 
UHLE, Max

1991 Pachacamac: report of the William Pepper, M.D., LL. D., Peruvian expedition of 1896, Department of Archaeology, University of Pennsylvania, Philadelphia [1903]. Republicado por The University Museum of Archaeology and Anthropology, University of Pennsylvania, Philadelphia.

VALLEJO, Francisco

1988 "Riti funerari nel Perú preispanico: analisi di una tomba del complesso cimiteriale di Armatambo". En: Ande: preistoria come progetto, documenti etno-archeologia precolombiana. Editado por Maria Lunghi, pp. 381-443. Brescia: Universita Católica dil Sacro Cuore.

2009 "La problemática de la cerámica Ychsma: El estado de la situación y algunos elementos de discusión". Revista de Antropología 19: 133-168. Santiago: Facultad de Ciencias Sociales, Universidad de Chile.

VANSTAN, Ina

1954 "Weaver education in ancient Peru". Anthropology, Florida State University Studies 16: 87-120. Tallahassee: Florida State University.

YOUNG-SÁNCHEZ, Margaret

1992 "Textile traditions of the Late Intermediate Period". En: To weave for the sun: Andean textiles in the Museum of Fine Arts, Boston. Editado por Rebecca Stone-Miller, pp. 43-49. New York and London: Thames and Hudson. 